УДК 004.8

05.00.00 Технические науки

ПРИМЕНЕНИЕ ТЕОРИИ ИНФОРМАЦИИ И
КОГНИТИВНЫХ ТЕХНОЛОГИЙ ДЛЯ РЕШЕНИЯ ЗАДАЧ ГЕНЕТИКИ (на примере вЫчисления количества информации в генах о признаках и свойствах различных автохтонных сортов винограда)

Луценко Евгений Вениаминович

д.э.Н., к.Т.н., профессор

РИНЦ SPIN-код: 9523-7101

prof.lutsenko@gmail.com

Кубанский государственный аграрный университет имени И.Т. Трубилина, Краснодар, Россия

Трошин Леонид Петрович

Заслуженный деятель науки Кубани,

д. б. н., профессор

РИНЦ SPIN-код: 3386-2768

lptroshin@mail.ru

Кубанский государственный аграрный университет имени И.Т. Трубилина, Краснодар, Россия

Общеизвестно, что генетика изучает механизмы изменчивости/наследственности и очень широко пользуется понятием «наследственная информация». При этом генетика под информацией подразумевает содержание генетического кода - структуры молекул ДНК и РНК, входящих в состав клетки живого организма. Генетика изучает механизмы записи, копирования, считывания генетической информации, возможности ее модификации, а также ее влияние на признаки и свойства организма. В разговорном и научном языке прочно закрепились фразы, типа «Гены содержат информацию о признаках/свойствах организма». Парадоксально, но мы не видим попыток определения количества информации, содержащейся в конкретных генах о конкретных фенотипических признаках или свойствах организма. Казалось бы, применение теории информации в генетике является совершенно естественным и напрашивается само собой. Тем более странно, что практически нет работ, посвященных применению теории информации для решения задач генетики. Данная статья призвана в какой-то степени восполнить этот пробел на примере вычисления количества информации в генах о признаках или свойствах различных сортов винограда. В ней рассматривается применение автоматизированного системно-когнитивного анализа (АСКанализ), его математической модели - системной теории информации и реализующего их программного инструментария - интеллектуальной системы «Эйдос» для решения одной из важных задач генетики: определения количества информации, содержащейся в генах о различных фенотипических признаках/свойствах винограда. Для решения этой зада-
UDC 004.8

Technical sciences

\section{APPLICATION OF THE INFORMATION THEORY AND COGNITIVE TECHNOLOGIES FOR SOLVING PROBLEMS OF GENETICS (on the example of calculation of the amount of information in the genes about characteristics and properties of the various indigenous grape varieties)}

Lutsenko Eugeny Veniaminovich

Dr.Sci.Econ., Cand.Tech.Sci., professor

RSCI SPIN-code: 9523-7101

prof.lutsenko@gmail.com

Kuban State Agrarian University, Krasnodar, Russia

Troshin Leonid Petrovich

Dr.Sci.Biol., professor

RSCI SPIN-code: 3386-2768

lptroshin@mail.ru

\section{Kuban State Agrarian University, Krasnodar, Russia}

It is well known that genetics studies the mechanisms of variation/heredity and widely uses the concept of "genetic information". While genetics considers the information as the content of the genetic code - structure of DNA and RNA included in the cell of a living organism. Genetics examines the mechanisms of recording, copying, readout of genetic information, the possibility of its modification and its influence on the characteristics and properties of the organism. In conversational and scientific language we know phrases, such as "Genes contain information about the characteristics/properties of the body." Paradoxically, we see no attempts to determine the amount of information contained in specific genes on specific characteristics or phenotypic properties of the organism. It would seem that the application of information theory in genetics is a completely natural and suggests itself. More strange that there are practically no works devoted to the application of information theory for solving problems of genetics. This article is intended, to some extent, to fill this gap on the example of calculating the amount of information in the genes of the characteristics or properties of different grape varieties. It examines the application of automated system-cognitive analysis (ASC-analysis), its mathematical model system of information theory and software tools intellectual system called "Eidos" for solving one of the important tasks of genetics: determine the amount of information contained in the genes on various phenotypic characteristics/properties of the grapes. To solve this problem, we perform the fol- 
чи выполняются следующие этапы: 1) когнитивноцелевая структуризация предметной области; 2) формализация предметной области, т.е. разработка классификационных и описательных шкал и градаций и обучающей выборки; 3) синтез и верификация информационной модели, отражающей количество информации в генах о фенотипических признаках/свойствах (многопараметрическая типизация); 4) вывод информации о генетической системе детерминации фенотипических признаков/свойств (SWOTанализ феносвойства); 5) вывод информации о силе и направлении влияния конкретного гена на фенотипические признаки/свойства (SWOT-диаграммы генов); 6) решение задачи системной идентификации фенотипических признаков/свойств по наличию тех или иных генов; 7) количественное определение сходства-различия различных фенотипических признаков/свойств по их системе детерминации генами. Конкретное фенотипическое свойство (или признак) рассматривается как зашумленный генетический текст, включающий как генетическую информацию об истинном феносвойстве (чистый сигнал), так и шум, искажающий эту информацию, обусловленный случайным воздействием окружающей среды. Программный инструментарий АСК-анализа - интеллектуальная система «Эйдос» обеспечивает подавление шума и выделение истинного сигнала

КЛючевЫе слова: МНОГОПАРАМЕТРИЧЕСКАЯ ТИПИЗАЦИЯ, СИСТЕМНАЯ ИДЕНТИФИКАЦИЯ, ВИНОГРАД, ГЕНОМ, ГЕН, ДНК, РНК, ГЕНЕТИЧЕСКИЙ КОД, АСК-АНАЛИЗ, АВТОМАТИЗИРОВАННЫЙ СИСТЕМНОКОГНИТИВНЫЙ АНАЛИЗ, СИСТЕМА «ЭЙДОС» Doi: 10.21515/1990-4665-121-003

\section{СОДЕРЖАНИЕ}

1. ФОРМУЛИРОВКА ПРОБЛЕМЫ....

. ИД Я И ПРЕДПОСЫЛКИ РЕШЕНИЯ ПРОБЛЕМЫ

3. АВТОМАТИЗИРОВАННЫЙ СИСТЕМНО-КОГНИТИВНЫЙ АНАЛИЗ КАК МЕТОД РЕШЕНИЯ ПРОБЛЕМЫ................ 4

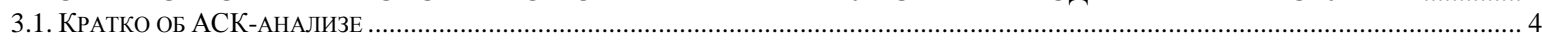

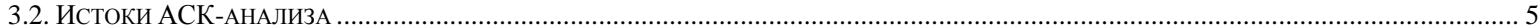

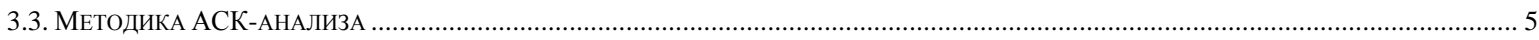

3.4. НЕКОТОРЫЕ РЕЗУЛЬТАТЫ ПРИМЕНЕНИЯ АСК-АНАЛИЗА В РАЗЛИЧНЫХ ПРЕДМЕТНЫХ ОБЛАСТЯХ ……......................................... 9

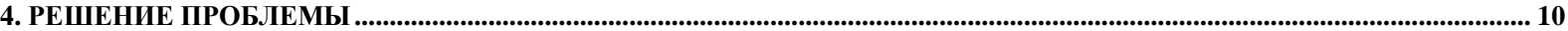

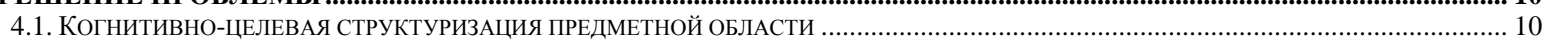

4.2. ФОРМАЛИЗАЦИЯ ПРЕДМЕТНОЙ ОБЛАСТИ, Т.Е. РАЗРАБОТКА КЛАССИФИКАЦИОННЫХ И ОПИСАТЕЛЬНЫХ ШКАЛ И ГРАДАЦИЙ И

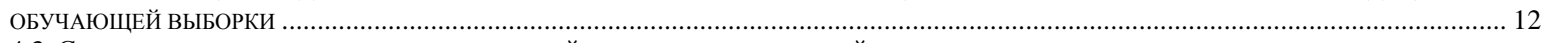

4.3. СИНТЕЗ И ВЕРИФИКАЦИЯ ИНФОРМАЦИОННОЙ МОДЕЛИ, ОТРАЖАЮЩЕЙ КОЛИЧЕСТВО ИНФОРМАЦИИ В ГЕНАХ О

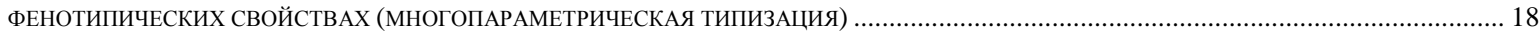

4.4. РЕШЕНИЕ ЗАДАЧИ СИСТЕМНОЙ ИДЕНТИФИКАЦИИ ФЕНОТИПИЧЕСКИХ ПРИЗНАКОВ И СВОЙСТВ ПО НАЛИЧИЮ ТЕХ ИЛИ ИНЫХ

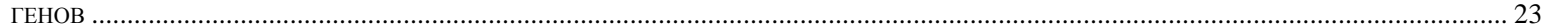

4.5. АВТОМАТИЗИРОВАННЫЙ SWOT-АНАЛИЗ СИСТЕМЫ ДЕТЕРМИНАЦИИ ФЕНОТИПИЧЕСКИХ ПРИЗНАКОВ И СВОЙСТВ СТРУКТУРОЙ

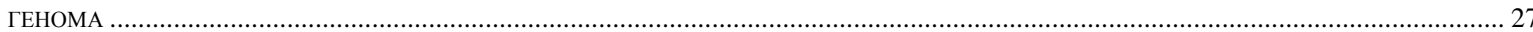

4.6. АВТОМАТИЗИРОВАННЫЙ SWOT-АНАЛИЗ СИЛЫ И НАПРАВЛЕНИЯ ВЛИЯНИЯ КОНКРЕТНОГО ГЕНА НА ФЕНОТИПИЧЕСКИЕ

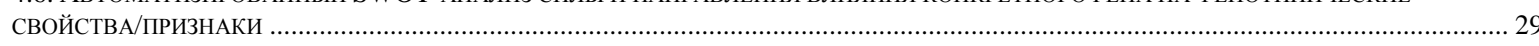

4.7. КОЛИЧЕСТВЕННОЕ ОПРЕДЕЛЕНИЕ СХОДСТВА-РАЗЛИЧИЯ РАЗЛИЧНЫХ ФЕНОТИПИЧЕСКИХ СВОЙСТВ ПО ИХ СИСТЕМЕ

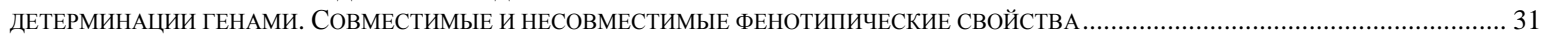

4.8. КОЛИЧЕСТВЕННОЕ ОПРЕДЕЛЕНИЕ СХОДСТВА-РАЗЛИЧИЯ РАЗЛИЧНЫХ ГЕНОВ ПО ИХ ВЛИЯНИЮ НА ФЕНОТИПИЧЕСКИХ СВОЙСТВА.

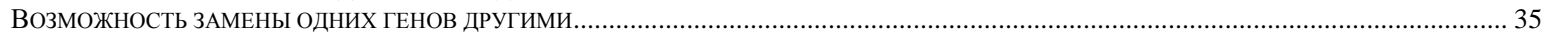

4.9. АЛГОРИТМ ПРИНЯТИЯ РЕШЕНИЯ О СТРУКТУРЕ ГЕНОМА С ЦЕЛЬЮ СОЗДАНИЯ НОВОГО СОРТА С ЗАДАННОЙ СИСТЕМОЙ

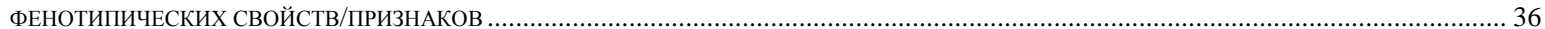

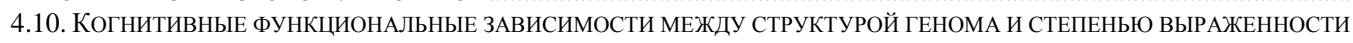

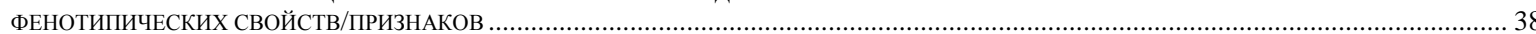

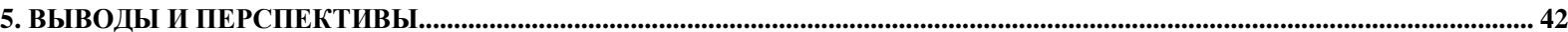

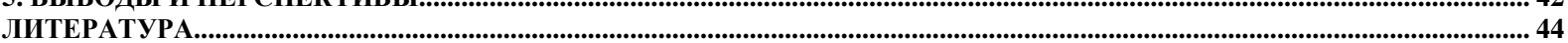

http://ej.kubagro.ru/2016/07/pdf/03.pdf 


\section{1. Формулировка проблемы}

Общеизвестно, что генетика изучает механизмы наследственности и изменчивости и очень широко пользуется понятием «наследственная информация». При этом генетика под информацией подразумевает содержание генетического кода - структуры молекул ДНК и РНК, входящих в состав клетки живого организма. Генетика изучает механизмы записи, копирования, считывания генетической информации, возможности ее модификации, а также ее влияние на признаки и свойства организма. В разговорном и научном языке прочно закрепились фразы, типа «Гены содержат информацию о признаках и свойствах организма». Парадоксально, но мы не видим систематических попыток определения количества информации, содержащейся в конкретных генах о конкретных фенотипических признаках и свойствах организма. Казалось бы, применение теории информации в генетике является совершенно естественным и напрашивается само собой. Тем более странно, что практически нет работ, посвященных применению теории информации для решения задач генетики.

В качестве исключения приведем две цитаты из работ 1980 и 1974 годов, в которых совершенно четко осознается роль информации в генетике $[46,47]$ «Абсолютным критерием живого принято считать наличие определенного количества бит информации, заключенных в информационных молекулах» $[46,47]$. «...быстрый рост количества информации дал новое качество - способность к самовоспроизведению (качество, присущее только нуклеиновым кислотам, обладающим несравненной со всеми другими соединениями нашего мира информационной емкостью; качество давшее начало новой форме существования материи)» [46] (курсив наш. авт.). И все же конкретных расчетов количества информации в генах не приводится и в этих работах.

Данная статья призвана представить научной общественности один из возможных вариантов решения этой проблемы на примере вычисления количества информации в генах о признаках и свойствах различных сортов винограда.

\section{2. Идея и предпосылки решения проблемы}

По-видимому, сформулированная проблема обусловлена отсутствием доступа у исследователей-генетиков к программному инструментарию, реализующему теорию информации и обеспечивающему решение задач генетики с применением теории информации. Между тем, такой инструментарий существует и находится в полном открытом и бесплатном доступе: это - автоматизированный системно-когнитивный анализ (АСК-анализ) [1], его математическая модель - системная теория информации [2] и реализующий их программный инструментарий - интеллектуальная система «Эйдос» [3]. 
Этот инструментарий обеспечивает решение одной из важных задач генетики: определения количества информации, содержащейся в генах о различных фенотипических признаках и свойствах винограда. Впервые в четкой и развитой форме эта мысль высказана автором в статье [4].

Для решения этой задачи выполняются следующие этапы АСКанализа [1]: 1) когнитивно-целевая структуризация предметной области; 2) формализация предметной области, т.е. разработка классификационных и описательных шкал и градаций и обучающей выборки; 3) синтез и верификация информационной модели, отражающей количество информации в генах о фенотипических признаках и свойствах (многопараметрическая типизация); 4) вывод информации о генетической системе детерминации фенотипических признаков и свойств (SWOT-анализ феносвойства); 5) вывод информации о силе и направлении влияния конкретного гена на фенотипические признаки и свойства (SWOT-диаграммы генов); 6) решение задачи системной идентификации фенотипических признаков/свойств по наличию тех или иных генов; 7) количественное определение сходстваразличия различных фенотипических признаков/свойств по их системе детерминации генами. Конкретное фенотипическое свойство (или признак) рассматривается как зашумленный генетический текст, включающий как генетическую информацию об истинном феносвойстве (чистый сигнал), так и шум, искажающий эту информацию, обусловленный случайным воздействием окружающей среды. Программный инструментарий АСКанализа - интеллектуальная система «Эйдос» обеспечивает подавление шума и выделение истинного сигнала.

Имеется большой опыт успешного применения АСК-анализа для решения широкого круга задач в различных предметных областях.

\section{3. Автоматизированный системно-когнитивный анализ как метод решения проблемы}

\section{1. Кратко об АСК-анализе}

Системный анализ представляет собой современный метод научного познания, общепризнанный метод решения проблем $[5,6]$. Однако возможности практического применения системного анализа ограничиваются отсутствием программного инструментария, обеспечивающего его автоматизацию. Существуют разнородные программные системы, автоматизирующие отельные этапы или функции системного анализа в различных конкретных предметных областях.

Автоматизированный системно-когнитивный анализ (АСКанализ) представляет собой системный анализ, структурированный по базовым когнитивным операциям (БКО), благодаря чему удалось разработать для него математическую модель, методику численных расчетов (структуры данных и алгоритмы их обработки), а также реализующую их программную систему - систему «Эйдос» [1-3, 7]. Систе- 
ма «Эйдос» разработана в постановке, не зависящей от предметной области, и имеет ряд программных интерфейсов с внешними данными различных типов [3]. АСК-анализ может быть применен как инструмент, многократно усиливающий возможности естественного интеллекта во всех областях, где используется естественный интеллект. АСК-анализ был успешно применен для решения задач идентификации, прогнозирования, принятия решений и исследования моделируемого объекта путем исследования его модели во многих предметных областях, в частности в экономике, технике, социологии, педагогике, психологии, медицине, экологии, ампелографии, геофизике, энтомологии, криминалистике и др. [8, 9].

\section{2. Истоки АСК-анализа}

Известно, что системный анализ является одним из общепризнанных в науке методов решения проблем и многими учеными рассматривается вообще как метод научного познания. Однако, как впервые заметил еще в 1984 году проф. И.П. Стабин, на практике применение системного анализа наталкивается на проблему [10]. Суть этой проблемы в том, что обычно системный анализ успешно применяется в сравнительно простых случаях, в которых в принципе можно обойтись и без него, тогда как в действительно сложных ситуациях, когда он действительно чрезвычайно востребован и у него нет альтернатив, сделать это удается гораздо реже. Проф. И.П. Стабин предложил и путь решения этой проблемы, который он видел в автоматизации системного анализа [10].

Однако путь от идеи до создания программной системы долог и сложен, т.к. включает ряд этапов:

- выбор теоретического математического метода;

- разработка методики численных расчетов, включающей структуры данных в оперативной памяти и внешних баз данных (даталогическую и инфологическую модели) и алгоритмы обработки этих данных;

- разработка программной системы, реализующей эти математические методы и методики численных расчетов.

\section{3. Методика АСК-анализа}

\subsection{1. Предпосылки решения проблемы}

Перегудов Ф.И. и Тарасенко Ф.П. в своих основополагающих работах 1989 и 1997 годов [5, 6] подробно рассмотрели математические методы, которые в принципе могли бы быть применены для автоматизации отдельных этапов системного анализа. Однако даже самые лучшие математические методы не могут быть применены на практике без реализующих их программных систем, а путь от математического метода к программной системе долог и сложен. Для этого необходимо разработать численные методы или методики численных расчетов (алгоритмы и структуры данных), 
реализующие математический метод, а затем разработать программную реализацию системы, основанной на этом численном методе.

В числе первых попыток реальной автоматизации системного анализа следует отметить докторскую диссертацию проф. Симанкова В.С. (2001) [11]. Эта попытка была основана на высокой детализации этапов системного анализа и подборе уже существующих программных систем, автоматизирующих эти этапы. Идея была в том, что чем выше детализация системного анализа, чем мельче этапы, тем проще их автоматизировать. Эта попытка была реализована, однако, лишь для специального случая исследования в области возобновляемой энергетики, т.к. системы оказались различных разработчиков, созданные с помощью различного инструментария и не имеющие программных интерфейсов друг с другом, т.е. не образующие единой автоматизированной системы. Эта попытка, безусловно, явилась большим шагом по пути, предложенному проф. И.П. Стабиным, но и ее нельзя признать обеспечившей достижение поставленной цели, сформулированной Стабиным И.П. (т.е. создание автоматизированного системного анализа), т.к. она не привела к созданию единой универсальной программной системы, автоматизирующий системный анализ, которую можно было бы применять в различных предметных областях.

Необходимо отметить работы Дж. Клира по системологии и автоматизации решения системных задач, которые внесли большой вклад в автоматизацию системного анализа путем создания и применения универсального решателя системных задач (УРС3), реализованного в рамках оригинальной экспертной системы $[12,13]$. Однако в экспертной системе применяется продукционная модель знаний, для получения которых от эксперта необходимо участие инженера по знаниям (когнитолога). Этим обусловлены следующие недостатки экспертных систем:

- они генерируют знания каждый раз, когда они необходимы для решения задач, и это может занимать значительно большее время, чем при использовании декларативной формы представления знаний;

- продукционные модели обычно построены на бинарной логике (if then else), что вызывает возможность логического конфликта продукций в процесс логического вывода, что приводит к необратимому останову логического процесса;

- эксперты - люди чаще всего заслуженные и их время и знания стоят очень дорого; поэтому привлечение экспертов для извлечения готовых знаний на длительное время проблематично и обычно эксперт просто физически не может сообщить очень большой объем знаний, а иногда и не хочет этого делать и сообщает неадекватные знания;

- чаще всего эксперты формулируют свои знания неформализуемым путем на основе своей интуиции, опыта и профессиональной компетенции, т.е. не могут сформулировать свои знания в количественной форме, а пользуются для их формализации порядковыми или даже номинальными 
шкалами, поэтому экспертные знания являются не очень точными и для их формализации необходим инженер по знаниям (когнитолог).

\subsection{2. АСК-анализ как решение проблемы}

Автоматизированный системно-когнитивный анализ разработан профессором Е.В. Луценко и предложен в 2002 году [1], хотя разработан он был значительно раньше, причем с программным инструментарием: системой «Эйдос» $[1,3,7]$. Основная идея, позволившая сделать это, состоит в рассмотрении системного анализа как метода познания (отсюда и «когнитивный» от «cognitio» - знание, познание, лат.). Эта идея позволила структурировать системный анализ не по этапам, как пытались сделать ранее, а по базовым когнитивным операциям системного анализа (БКОСА), т.е. таким операциям, к комбинациям которых сводятся остальные. Эти операции образуют минимальную систему, достаточную для описания системного анализа, как метода познания, т.е. конфигуратор. Понятие конфигуратора предложено В.А. Лефевром [14]. В 2002 году Е.В. Луценко был предложен когнитивный конфигуратор [1], включающий 10 базовых когнитивных операций.

\section{Когнитивный конфигуратор:}

1) присвоение имен;

2) восприятие (описание конкретных объектов в форме онтологий, т.е. их признаками и принадлежностью к обобщающим категориям - классам);

3) обобщение (синтез, индукция);

4) абстрагирование;

5) оценка адекватности модели;

6) сравнение, идентификация и прогнозирование;

7) дедукция и абдукция;

8) классификация и генерация конструктов;

9) содержательное сравнение;

10) планирование и поддержка принятия управленческих решений.

Каждая из этих операций оказалась достаточно элементарна для формализации и программной реализации.

Компоненты АСК-анализа:

- формализуемая когнитивная концепция и следующий из нее когнитивный конфигуратор;

- теоретические основы, методология, технология и методика АСКанализа;

- математическая модель АСК-анализа, основанная на системном обобщении теории информации;

- методика численных расчетов, в универсальной форме реализующая математическую модель АСК-анализа, включающая иерархическую структуру данных и 24 детальных алгоритма 10 БКОСА; 
- специальное инструментальное программное обеспечение, реализующее математическую модель и численный метод АСК-анализа - Универсальная когнитивная аналитическая система "Эйдос".

\section{Этапы АСК-анализа:}

1) когнитивно-целевая структуризация предметной области;

2) формализация предметной области (конструирование классификационных и описательных шкал и градаций и подготовка обучающей выборки);

3) синтез системы моделей предметной области (в настоящее время система «Эйдос» поддерживает 3 статистические модели и 7 системнокогнитивных моделей (моделей знаний);

4) верификация (оценка достоверности) системы моделей предметной области;

5) повышение качества системы моделей;

6) решение задач идентификации, прогнозирования и поддержки принятия решений;

7) исследование моделируемого объекта путем исследования его моделей является корректным, если модель верно отражает моделируемый объект и включает: кластерно-конструктивный анализ классов и факторов; содержательное сравнение классов и факторов; изучение системы детерминации состояний моделируемого объекта; нелокальные нейроны и интерпретируемые нейронные сети прямого счета; классические когнитивные модели (когнитивные карты); интегральные когнитивные модели (интегральные когнитивные карты), прямые обратные SWOT-диаграммы; когнитивные функции и т.д.

\section{Математические аспекты АСК-анализа}

Математическая модель АСК-анализ основана на теории информации, точнее на системной теории информации (СТИ), предложенной Е.В. Луценко [1, 2, 3] $]^{1}$. Это значит, что в АСК-анализе все факторы рассматриваются с одной единственной точки зрения: сколько информации содержится в их значениях о переходе объекта, на который они действуют, в определенное состояние, и при этом сила и направление влияния всех значений факторов на объект измеряется в одних общих для всех факторов единицах измерения: единицах количества информации $[8,9]$.

Это напоминает подход Дугласа Хаббарда [15], но, в отличие от него, имеет открытый универсальный программный инструментарий (систему «Эйдос»), разработанный в постановке, не зависящей от предметной области [1-3]. К тому же на систему «Эйдос» уже в 1994 году было три патента РФ [3, 16 $\left.{ }^{2}\right]$, а первые акты ее внедрения датируются 1987 годом [1,

\footnotetext{
${ }^{1}$ Математическая модель АСК-анализа описана в ряде работ: http://elibrary.ru/author items.asp?authorid=123162

${ }^{2}$ См., например: http://lc.kubagro.ru/aidos/index.htm
} 
$3]^{3}$, тогда как основная работа Дугласа Хаббарда [15] появилась лишь в 2009 году. Это означает, что идеи АСК-анализа не только появились, но и были доведены до программной реализации в универсальной форме и применены в различных предметных областях на 22 с лишним года раньше появления работ Дугласа Хаббарда.

Поэтому АСК-анализ обеспечивает корректную сопоставимую обработку числовых и нечисловых данных, представленных в разных типах измерительных шкал и разных единицах измерения [8, 9]. Метод АСКанализа является устойчивым непараметрическим методом, обеспечивающим создание моделей больших размерностей при неполных и зашумленных исходных данных о сложном нелинейном динамичном объекте управления. Этот метод является чуть ли не единственным на данный момент, обеспечивающим многопараметрическую типизацию и системную идентификацию методов, инструментарий которого (интеллектуальная система «Эйдос») находится в полном открытом бесплатном доступе $[3,16]^{4}$.

\section{4. Некоторые результаты применения АСК-анализа в различных предметных областях}

Метод системно-когнитивного анализа и его программный инструментарий интеллектуальная система "Эйдос" были успешно применены при проведении 6 докторских и 7 кандидатских диссертационных работ в ряде различных предметных областей по экономическим, техническим, психологическим и медицинским наукам.

АСК-анализ был успешно применены при выполнении десятков грантов РФФИ и РГНФ различной направленности за длительный период с 2002 года по настоящее время (2016 год).

По проблематике АСК-анализа издана 21 монография, получено 29 патентов на системы искусственного интеллекта, их подсистемы, режимы и приложения, опубликовано более 200 статей в изданиях, входящих в Перечень ВАК РФ (по данным РИНЦ). В одном только Научном журнале КубГАУ (входит в Перечень ВАК РФ с 26-го марта 2010 года) автором АСК-анализа Луценко Е.В. опубликовано 186 статей общим объёмом 321,559 у.п.л., в среднем 1,729 у.П.л. на одну статью.

По этим публикациям, грантам и диссертационным работам видно, что АСК-анализ уже был успешно применен в следующих предметных областях и научных направлениях: экономика (региональная, отраслевая, предприятий, прогнозирование фондовых рынков), социология, эконометрика, биометрия, педагогика (создание педагогических измерительных инструментов и их применение), психология (личности, экстремальных ситуаций, профессиональных и учебных достижений, разработка и применение профессиограмм), сельское хозяйство (прогнозирование результатов при-

\footnotetext{
${ }^{3}$ http://lc.kubagro.ru/aidos/aidos02/PR-4.htm

${ }^{4}$ http://lc.kubagro.ru/aidos/_Aidos-X.htm
} 
менения агротехнологий, принятие решений по выбору рациональных агротехнологий и микрозон выращивания), экология, ампелография, геофизика (глобальное и локальное прогнозирование землетрясений, параметров магнитного поля Земли, движения полюсов Земли), климатология (прогнозирование Эль-Ниньо и Ла-Нинья), возобновляемая энергетика, мелиорация и управление мелиоративными системами, криминалистика, энтомология и ряд других областей.

АСК-анализ вызывает большой интерес во всем мире. Сайт автора АCК-анализа [16] посетило около 500 тыс. посетителей с уникальными IPадресами со всего мира. Еще около 500 тыс. посетителей открывали статьи по АСК-анализу в Научном журнале КубГАУ.

Необходимо отметить, что в развитии различных теоретических основ и практических аспектов АСК-анализа приняли участие многие ученые: д.э.н., к.т.н., проф. Луценко Е.В., Засл. деятель науки РФ, д.т.н., проф. Лойко В.И., к.ф.-м.н., Ph.D., проф., Трунев А.П. (Канада), д.э.н., д.т.н., к.ф.м.н., проф. Орлов А.И., к.т.н., доц. Коржаков В.Е., д.э.н., проф. Барановская Т.П., д.э.н., к.т.н., проф. Ермоленко В.В., к.пс.н. Наприев И.Л., к.пс.н., доц. Некрасов С.Д., к.т.н., доц. Лаптев В.Н., к.пс.н, доц. Третьяк В.Г., к.пс.н., Щукин Т.Н., д.т.н., проф. Симанков В.С., д.э.н., проф. Ткачев А.Н., д.т.н., проф. Сафронова Т.И., д.э.н., доц. Горпинченко К.Н., к.э.н., доц. Макаревич О.А., к.э.н., доц. Макаревич Л.О., к.м.н. Сергеева Е.В. (Фомина Е.В.), Бандык Д.К. (Белоруссия), Чередниченко Н.А., к.ф.-м.н. Артемов А.А., д.э.н., проф. Крохмаль В.В., д.т.н., проф. Рябцев В.Г., к.т.н., доц. Марченко А.Ю., д.т.н., проф. Фролов В.Ю., д.ю.н, проф. Швец С.В., Засл. деятель науки Кубани, д.б.н., проф. Трошин Л.П., Засл. изобр. РФ, д.т.н., проф. Серга Г.В., Сергеев А.С., д.б.н., проф. Стрельников В.В. и другие.

\section{4. Решение проблемы}

В данном разделе рассмотрим решение поставленной проблемы путем последовательного выполнения различных этапов АСК-анализа [1].

\section{1. Когнитивно-целевая структуризация предметной области}

На этом этапе экспертом неформализуемым путем на основе опыта, интуиции и профессиональной компетенции определяется, что является причинами (факторами), а что следствиями (результатами действия факторов) в моделируемой предметной области.

В нашем случае вполне очевидно, что как факторы целесообразно рассматривать количество резервных генов различных видов, а как результаты их действия - различные фенотипические признаки или свойства различных сортов винограда. 
В таблице 1 представлены классификационные шкалы, с помощью которых будут кодироваться фенотипические признаки, а в таблице 2 описательные шкалы, т.е. резервные гены на 1-й и 2-й спиралях ДНК:

Таблица 1 - Классификационные шкалы

\begin{tabular}{|l|l|}
\hline Код & Наименование \\
\hline 1 & ТИП ЦВЕТКА (151) \\
\hline 2 & СРЕДНЯЯ МАССА ГРОЗДИ, Г \\
\hline 3 & УРОЖАЙНОСТЬ, Ц/ГА \\
\hline 4 & САХАРИСТОСТЬ, Г/100 КУБ. СМ \\
\hline 5 & КИСЛОТНОСТЬ ТИТРУЕМАЯ, Г/Л \\
\hline 6 & РАССЕЧЕННОСТЬ ЛИСТЬЕВ (072) \\
\hline 7 & ПУЗЫРЧАТОСТЬ ЛИСТЬЕВ (075) \\
\hline 8 & ВЕРХНИЕ ВЫРЕЗКИ ЛИСТЬЕВ (094-1) \\
\hline 9 & НИЖНИЕ ВЫРЕЗКИ ЛИСТЬЕВ (094-2) \\
\hline 10 & ОПУШЕНИЕ ЛИСТЬЕВ (084) \\
\hline 11 & РАЗМЕР ГРОЗДИ (202) \\
\hline 12 & ПЛОТНОСТЬ ГРОЗДИ (204) \\
\hline 13 & РАЗМЕР ЯГОДЫ (220) \\
\hline 14 & ФОРМА ЯГОДЫ (223) \\
\hline 16 & ОКРАСКА ЯГОДЫ (225) \\
\hline 17 & АРОМАТ ЯГОДЫ (236) \\
\hline 18 & ПАПРАВЛЕНИЕ ИСПОЛЬЗОВАНИЯ (603) \\
\hline 19 & ПРОДОЛЖИТЕЛЬНОСТЬ ПРОДУКЦИОННОГО ПЕРИОДА, ДНИ \\
\hline 20 & РОСТ ПОБЕГОВ (351) \\
\hline
\end{tabular}

Таблица 2 - Описательные шкалы

\begin{tabular}{|c|c|c|c|c|c|}
\hline Код & Наименование & Код & Наименование & Код & Наименование \\
\hline 1 & VRZAG47-2 & 18 & VVMD25-1 & 35 & VVIV37-2 \\
\hline 2 & VRZAG47-1 & 19 & VVIP60-2 & 36 & VVIV37-1 \\
\hline 3 & VVS2-2 & 20 & VVIP60-1 & 37 & VVIH54-2 \\
\hline 4 & VVS2-1 & 21 & VVIB01-2 & 38 & VVIH54-1 \\
\hline 5 & VVMD7-2 & 22 & VVIB01-1 & 39 & VVMD24-2 \\
\hline 6 & VVMD7-1 & 23 & VRZAG83-2 & 40 & VVMD24-1 \\
\hline 7 & VVMD5-2 & 24 & VRZAG83-1 & 41 & VVIV67-2 \\
\hline 8 & VVMD5-1 & 25 & VVMD27-2 & 42 & VVIV67-1 \\
\hline 9 & VRZAG62-2 & 26 & VVMD27-1 & 43 & VVIN73-2 \\
\hline 10 & VRZAG62-1 & 27 & VVMD21-2 & 44 & VVIN73-1 \\
\hline 11 & VRZAG79-2 & 28 & VVMD21-1 & 45 & VMC4F3.1-2 \\
\hline 12 & VRZAG79-1 & 29 & VMC1B11-2 & 46 & VMC4F3.1-1 \\
\hline 13 & VVMD28-2 & 30 & VMC1B11-1 & 47 & VVIN16-2 \\
\hline 14 & VVMD28-1 & 31 & VVIQ52-2 & 48 & VVIN16-1 \\
\hline 15 & VVMD32-2 & 32 & VVIQ52-1 & 49 & VVIP31-2 \\
\hline 16 & VVMD32-1 & 33 & VRZAG67-2 & 50 & VVIP31-1 \\
\hline 17 & VVMD25-2 & 34 & VRZAG67-1 & & \\
\hline
\end{tabular}

Последующие этапы АСК-анализа автоматизированы в его инструментарии - интеллектуальной системе «Эйдос». 
4.2. Формализация предметной области, т.е. разработка классификационных и описательных шкал и градаций и обучающей выборки

На этапе формализации предметной области разрабатываются классификационные и описательные шкалы и градации и с их помощью кодируются исходные данные, в результате чего формируется обучающая выборка.

В соответствии с результатами когнитивно-целевой структуризации предметной области исходные данные представлены в виде Excel-таблицы (таблица 3). Полностью в статье таблица 3 не приводится из-за ее размерности: в ней 90 строк и 71 колонка. Но она (вместе с другими материалами по статье) приводится по ссылке: http://ej.kubagro.ru/2016/07/upload/03.zip.

Структура таблицы 3 соответствует требованиям системы «Эйдос», приведенным на рисунке 1 , точнее требованиям ее универсального программного интерфейса импорта данных из внешних баз данных (режим 2.3.2.2).

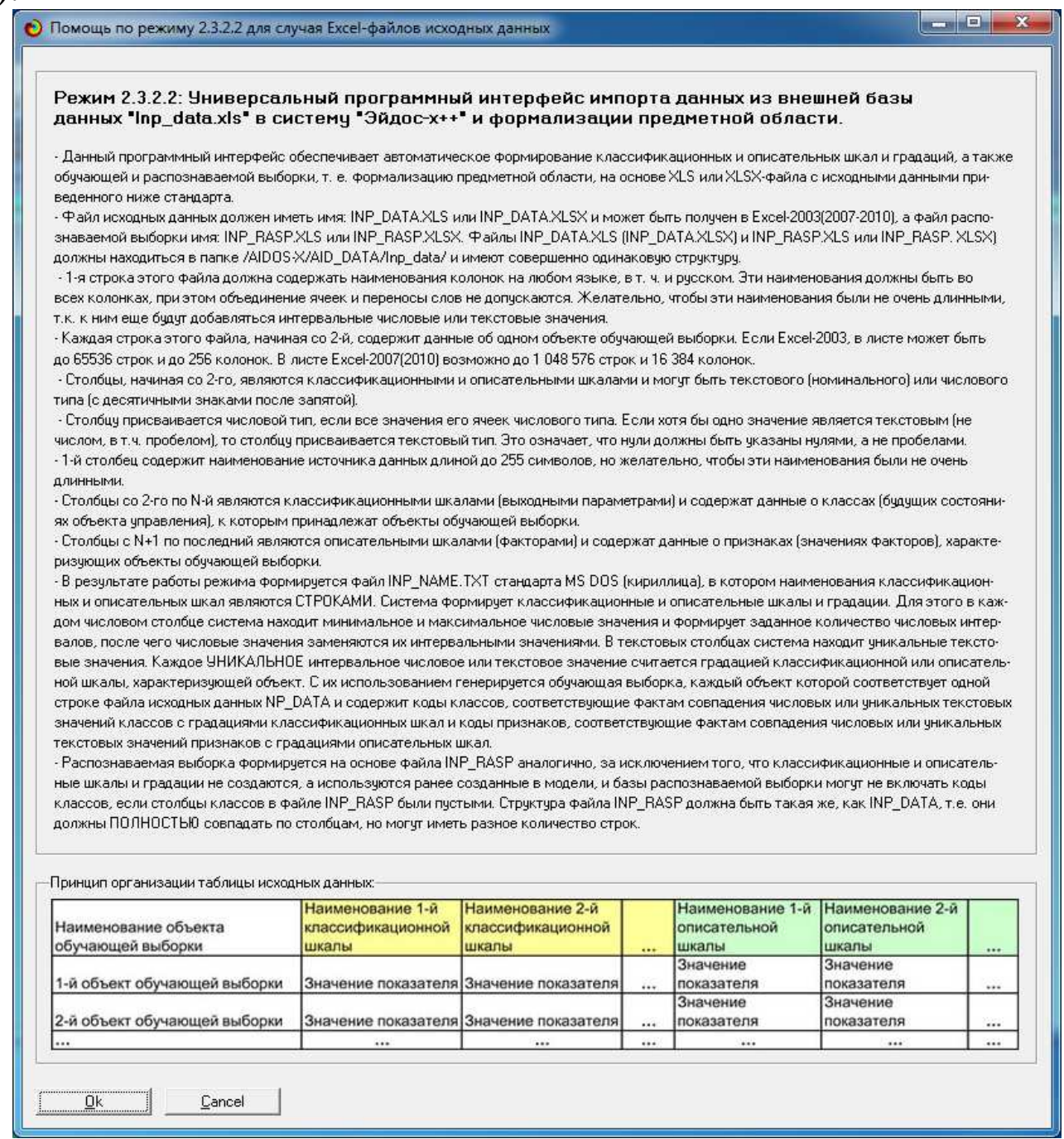

Рисунок 1. Требования к внешнему файлу исходных данных 
Таблица 3 - Исходные данные (фрагмент)

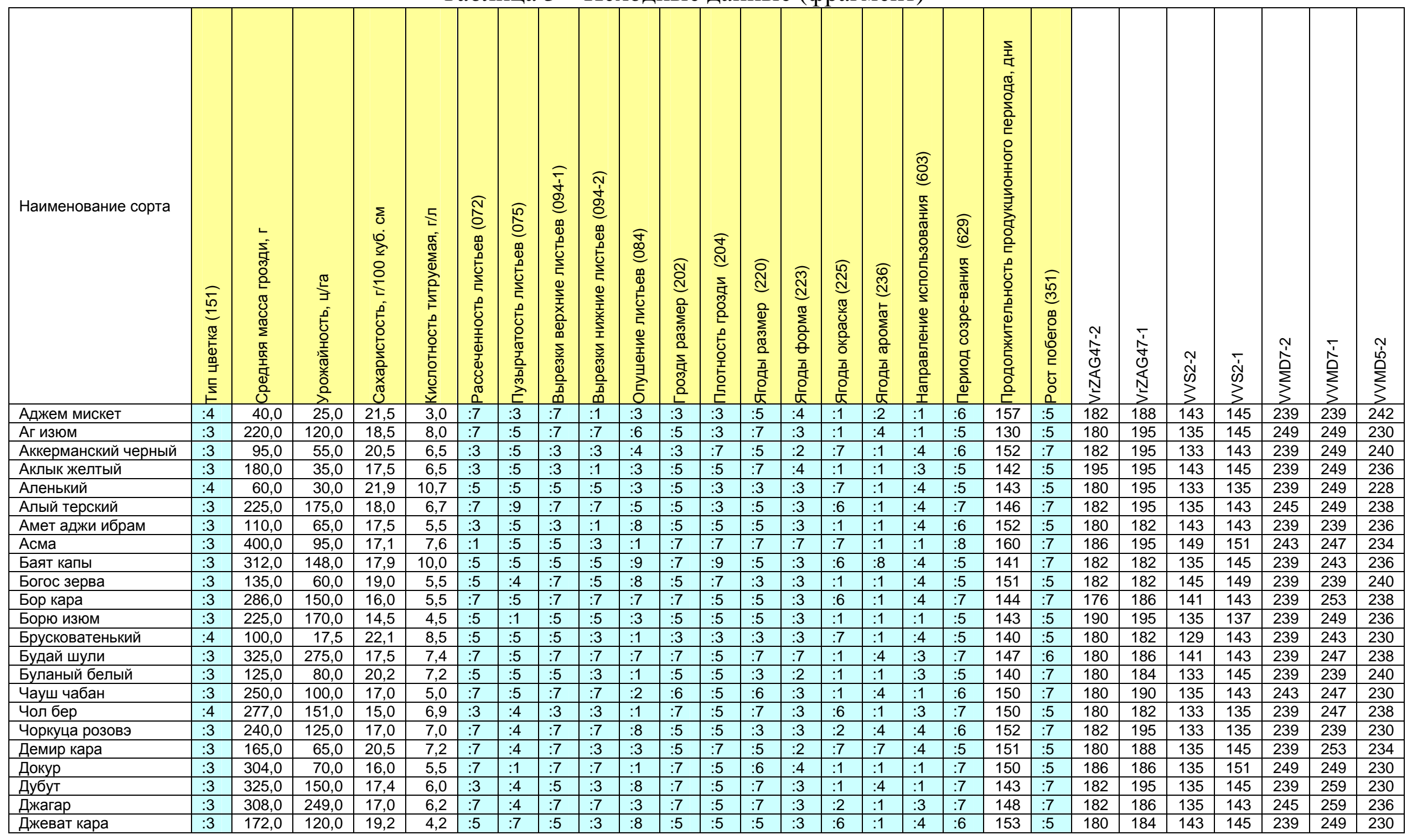

http://ej.kubagro.ru/2016/07/pdf/03.pdf 
В 1-й колонке таблицы приведены наименования сортов винограда. В колонках со 2-й по 21-ю приведены классификационные шкалы, с помощью градаций которых описывается степень выраженности фенотипических признаков и свойств. При этом и в наименованиях самих шкал, и в наименованиях их градаций используется общепринятая международная система кодирования фенотипических признаков и свойств (выделены светло-голубым фоном) [17]. В колонках с 22-й по 71-ю приведены наименования микросателлитных генов на 1-й и 2-й спиралях ДНК. В таблице 1 допускаются колонки с текстовым и числовым типом данных [26-45].

Резервные гены выбраны авторами для исследования по двум причинам:

- во-первых, потому, что по ним была информация;

- во-вторых, потому, что традиционно считается, что они не связаны с фенотипическими признаками и свойствами, что на самом деле не так, как показало данное исследование. Для ввода исходных из таблицы 3 в систему «Эйдос» и формирования классификационных и описательных шкал и градаций и обучающей выборки запускаем режим 2.3.2.2 с параметрами, приведенными на рисунке 2.

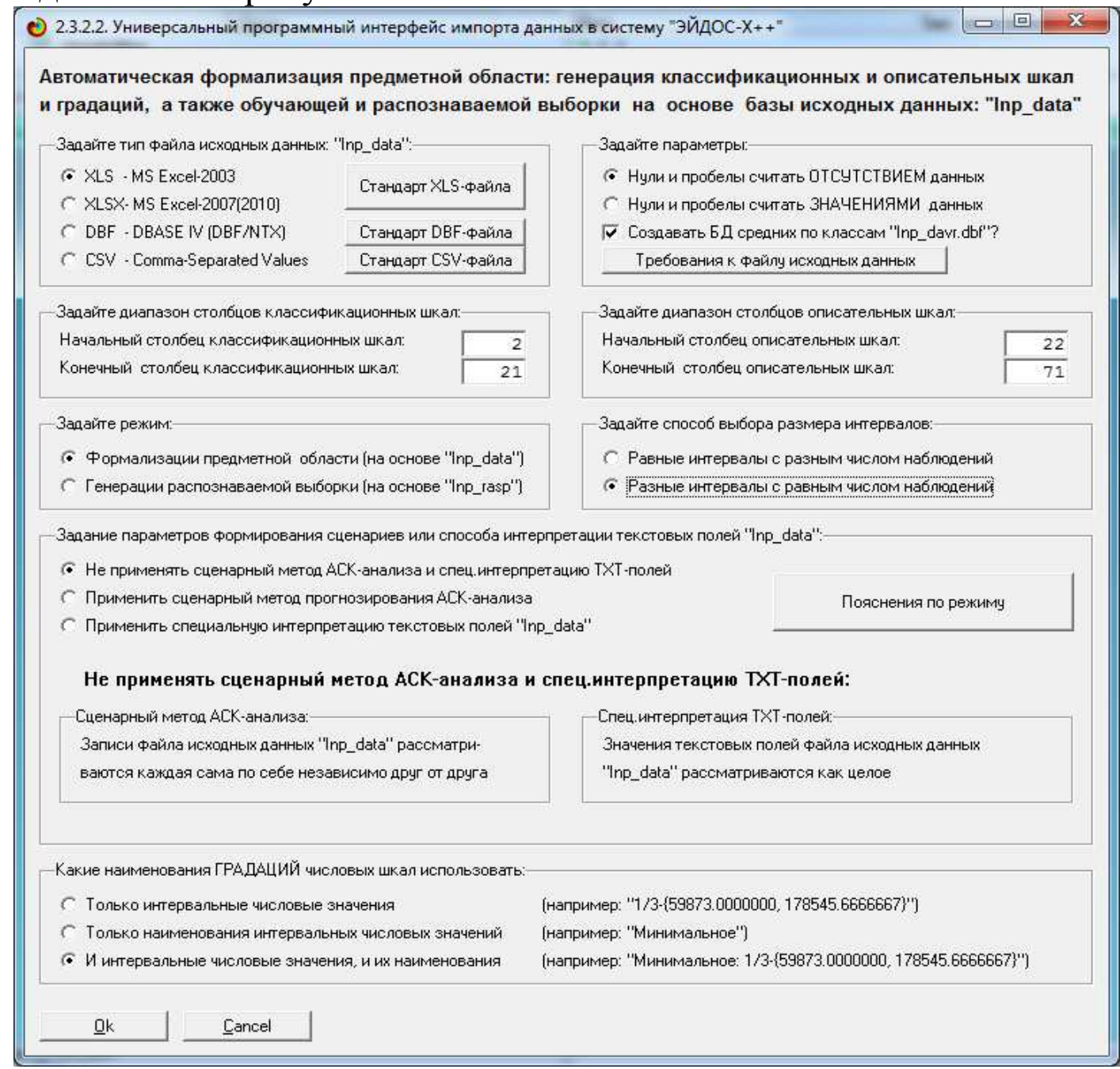

Рисунок 2. Параметры программного интерфейса импорта данных 
Во внутреннем калькулятор (рисунок 3) задаем по 5 градаций в числовых классификационных и описательных шкалах. В результате работы программного интерфейса получаем классификационные шкалы и градации (таблица 4), описательные шкалы и градации (таблица 5) и обучающую выборку или эвентологическую базу данных (таблица 6). Обучающая выборка (таблица 6) представляет собой исходные данные (таблица 1), закодированные с помощью классификационных и описательных шкал и градаций (таблицы 4, 5).

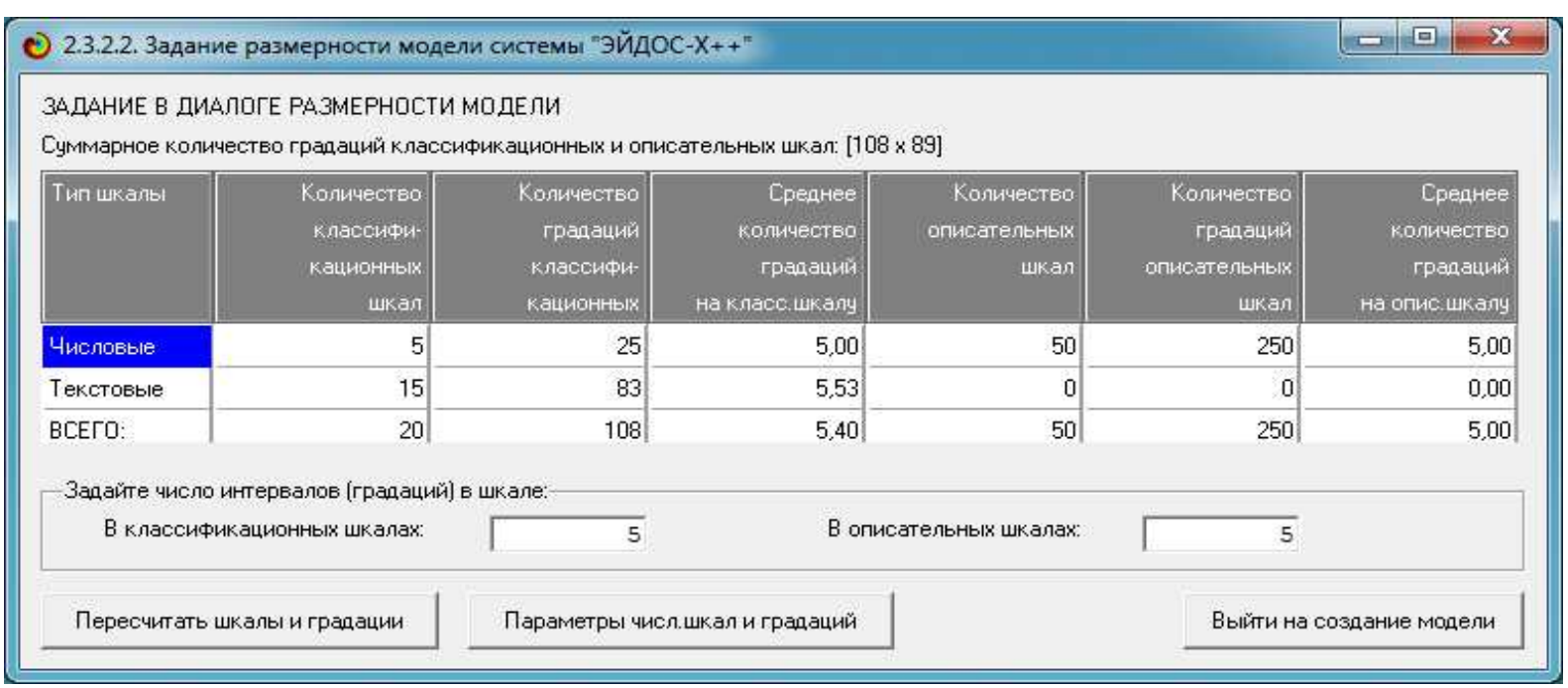

Рисунок 3. Внутренний калькулятор программного интерфейса импорта данных из внешних баз данных

В течение 3-х секунд формируются классификационные и описательные шкалы и градации и обучающая выборка (рисунок 4):

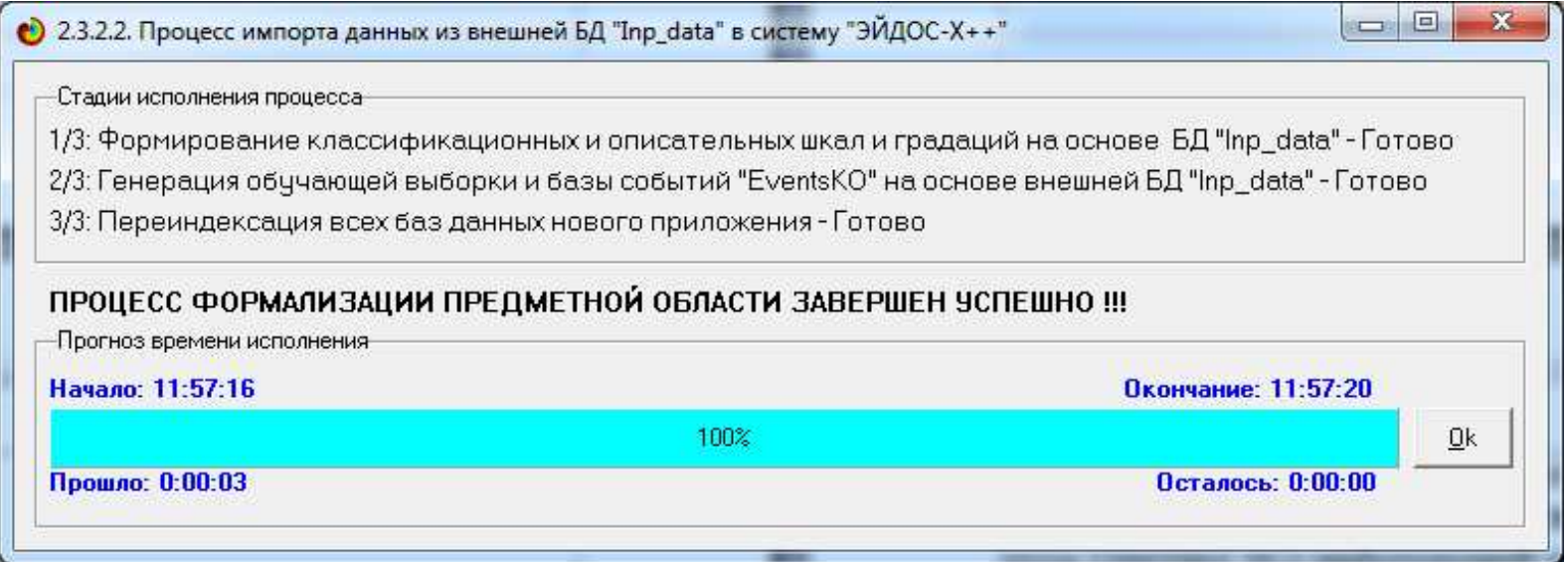

Рисунок 4. Отображение процесса формализации предметной области

В таблицах 4, 5, 6 и последующих часто приводятся лишь фрагменты таблиц из-за их большой размерности ограниченности объема статьи. Но полностью модель вместе с системой можно скачать по ссылке: http://ej.kubagro.ru/2016/07/upload/03.rar. 


\section{Таблица 4 - Классификационные шкалы и градации (фрагмент)}

\begin{tabular}{|c|c|}
\hline Код & Наименование класса \\
\hline 1 & ТИП ЦВЕТКА (151)-1/2-:3 \\
\hline 2 & ТИП ЦВЕТКА (151)-2/2-:4 \\
\hline 3 & СРЕДНЯЯ МАССА ГРОЗДИ, Г-Очень малое: $1 / 5-\{27.0000000,112.0000000\}$ \\
\hline 4 & СРЕДНЯЯ МАССА ГРОЗДИ, Г-Малое: 2/5-\{112.0000000, 173.0000000\} \\
\hline 5 & СРЕДНЯЯ МАССА ГРОЗДИ, Г-Среднее: 3/5-\{173.0000000, 220.0000000\} \\
\hline 6 & СРЕДНЯЯ МАССА ГРОЗДИ, Г-Большое: 4/5-\{220.0000000, 280.0000000$\}$ \\
\hline 7 & СРЕДНЯЯ МАССА ГРОЗДИ, Г-Очень большое: $5 / 5-\{280.0000000,400.0000000\}$ \\
\hline 8 & УРОЖАЙНОСТЬ, Ц/ГА-Очень малое: $1 / 5-\{9.0000000,60.0000000\}$ \\
\hline 9 & УРОЖАЙНОСТЬ, Ц/ГА-Малое: 2/5-\{60.0000000, 95.0000000 $\}$ \\
\hline 10 & УРОЖАЙНОСТЬ, Ц/ГА-Среднее: 3/5-\{95.0000000, 120.0000000\} \\
\hline 11 & УРОЖАЙНОСТЬ, Ц/ГА-Большое: 4/5-\{120.0000000, 170.0000000\} \\
\hline 12 & УРОЖАЙНОСТЬ, Ц/ГА-Очень большое: 5/5-\{170.0000000, 409.0000000\} \\
\hline 13 & САХАРИСТОСТЬ, Г/100 КУБ. СМ-Очень малое: $1 / 5-\{14.5000000,17.0000000\}$ \\
\hline 14 & САХАРИСТОСТЬ, Г/100 КУБ. СМ-Малое: 2/5-\{17.0000000, 18.0000000$\}$ \\
\hline 15 & САХАРИСТОСТЬ, Г/100 КУБ. СМ-Среднее: $3 / 5-\{18.0000000,18.7000000\}$ \\
\hline 16 & САХАРИСТОСТЬ, Г/100 КУБ. СМ-Большое: $4 / 5-\{18.7000000,20.5000000\}$ \\
\hline 17 & САХАРИСТОСТЬ, Г/100 КУБ. СМ-Очень большое: $5 / 5-\{20.5000000,24.0000000\}$ \\
\hline 18 & КИСЛОТНОСТЬ ТИТРУЕМАЯ, Г/Л-Очень малое: $1 / 5-\{2.8000000,5.5000000\}$ \\
\hline 19 & КИСЛОТНОСТЬ ТИТРУЕМАЯ, Г/Л-Малое: $2 / 5-\{5.5000000,6.4000000\}$ \\
\hline 20 & КИСЛОТНОСТЬ ТИТРУЕМАЯ, Г/Л-Среднее: $3 / 5-\{6.4000000,6.9000000\}$ \\
\hline 21 & КИСЛОТНОСТЬ ТИТРУЕМАЯ, Г/Л-Большое: 4/5-\{6.9000000, 7.8000000 $\}$ \\
\hline 22 & КИСЛОТНОСТЬ ТИТРУЕМАЯ, Г/Л-Очень большое: $5 / 5-\{7.8000000,10.7000000\}$ \\
\hline 23 & РАССЕЧЕННОСТЬ ЛИСТЬЕВ (072)-1/6-:1 \\
\hline 24 & РАССЕЧЕННОСТЬ ЛИСТЬЕВ (072)-2/6-:3 \\
\hline 25 & РАССЕЧЕННОСТЬ ЛИСТЬЕВ (072)-3/6-:5 \\
\hline 26 & РАССЕЧЕННОСТЬ ЛИСТЬЕВ (072)-4/6-:6 \\
\hline 27 & РАССЕЧЕННОСТЬ ЛИСТЬЕВ (072)-5/6-:7 \\
\hline 28 & РАССЕЧЕННОСТЬ ЛИСТЬЕВ (072)-6/6-:9 \\
\hline 29 & ПУЗЫРЧАТОСТЬ ЛИСТЬЕВ (075)-1/6-:1 \\
\hline 30 & ПУЗЫРЧАТОСТЬ ЛИСТЬЕВ (075)-2/6-:3 \\
\hline 31 & ПУЗЫРЧАТОСТЬ ЛИСТЬЕВ (075)-3/6-:4 \\
\hline 32 & ПУЗЫРЧАТОСТЬ ЛИСТЬЕВ (075)-4/6-:5 \\
\hline 33 & ПУЗЫРЧАТОСТЬ ЛИСТЬЕВ (075)-5/6-:7 \\
\hline 34 & ПУЗЫРЧАТОСТЬ ЛИСТЬЕВ (075)-6/6-:9 \\
\hline
\end{tabular}

\section{Таблица 5 - Описательные шкалы и градации (фрагмент)}

\begin{tabular}{|c|c|}
\hline Код & Наименование \\
\hline 1 & VRZAG47-2-Очень малое: 1/5-\{176.0000000, 180.0000000\} \\
\hline 2 & VRZAG47-2-Малое: 2/5-\{180.0000000, 182.0000000\} \\
\hline 3 & VRZAG47-2-Среднее: 3/5-\{182.0000000, 182.0000000\} \\
\hline 4 & VRZAG47-2-Большое: 4/5-\{182.0000000, 186.0000000\} \\
\hline 5 & VRZAG47-2-Очень большое: 5/5-\{186.0000000, 195.0000000\} \\
\hline 6 & VRZAG47-1-Очень малое: 1/5-\{180.0000000, 184.0000000\} \\
\hline 7 & VRZAG47-1-Малое: 2/5-\{184.0000000, 186.0000000\} \\
\hline 8 & VRZAG47-1-Среднее: 3/5-\{186.0000000, 190.0000000\} \\
\hline 9 & VRZAG47-1-Большое: 4/5-\{190.0000000, 195.0000000\} \\
\hline 10 & VRZAG47-1-Очень большое: 5/5-\{195.0000000, 195.0000000\} \\
\hline 11 & VVS2-2-Очень малое: 1/5-\{123.0000000, 133.0000000\} \\
\hline 12 & VVS2-2-Малое: 2/5-\{133.0000000, 135.0000000\} \\
\hline 13 & VVS2-2-Среднее: 3/5-\{135.0000000, 135.0000000\} \\
\hline 14 & VVS2-2-Большое: 4/5-\{135.0000000, 143.0000000\} \\
\hline 15 & VVS2-2-Очень большое: 5/5-\{143.0000000, 149.0000000\} \\
\hline 16 & VVS2-1-Очень малое: 1/5-\{135.0000000, 141.0000000\} \\
\hline 17 & VVS2-1-Малое: 2/5-\{141.0000000, 143.0000000\} \\
\hline 18 & VVS2-1-Среднее: 3/5-\{143.0000000, 143.0000000\} \\
\hline 19 & VVS2-1-Большое: 4/5-\{143.0000000, 145.0000000\} \\
\hline 20 & VVS2-1-Очень большое: 5/5-\{145.0000000, 155.0000000\} \\
\hline 21 & VVMD7-2-Очень малое: 1/5-\{231.0000000, 239.0000000\} \\
\hline 22 & VVMD7-2-Малое: 2/5-\{239.0000000, 239.0000000\} \\
\hline 23 & VVMD7-2-Среднее: 3/5-\{239.0000000, 239.0000000\} \\
\hline 24 & VVMD7-2-Большое: 4/5-\{239.0000000, 247.0000000\} \\
\hline 25 & VVMD7-2-Очень большое: 5/5-\{247.0000000, 249.0000000\} \\
\hline 26 & VVMD7-1-Очень малое: 1/5-\{235.0000000, 243.0000000\} \\
\hline 27 & VVMD7-1-Малое: 2/5-\{243.0000000, 247.0000000\} \\
\hline 28 & VVMD7-1-Среднее: 3/5-\{247.0000000, 249.0000000\} \\
\hline 29 & VVMD7-1-Большое: 4/5-\{249.0000000, 249.0000000\} \\
\hline 30 & VVMD7-1-Очень большое: 5/5-\{249.0000000, 265.0000000\} \\
\hline
\end{tabular}


Таблица 6 - Обучающая выборка (эвентологическая база данных) (фрагмент)

\begin{tabular}{|c|c|c|c|c|c|c|c|c|c|c|c|c|c|c|c|c|c|c|c|c|c|c|c|c|c|c|c|c|c|c|c|c|}
\hline NAME_OBJ & N2 & N3 & N4 & N5 & N6 & \begin{tabular}{|l|} 
N7 \\
\end{tabular} & N8 & N9 & \begin{tabular}{|l|} 
N10 \\
\end{tabular} & N11 & \begin{tabular}{|l|}
$\mathrm{N} 12$ \\
\end{tabular} & N13 & N14 & N15 & N16 & \begin{tabular}{|l|}
$\mathrm{N} 17$ \\
\end{tabular} & N18 & N19 & N20 & N21 & N22 & N23 & N24 & N25 & N26 & \begin{tabular}{|l|} 
N27 \\
\end{tabular} & N28 & \begin{tabular}{|l|} 
N29 \\
\end{tabular} & N30 & N31 & \begin{tabular}{|l|} 
N32 \\
\end{tabular} & N33 \\
\hline Аджем мискет & 2 & 3 & 8 & 17 & 18 & 27 & 30 & 38 & 40 & 47 & 54 & 60 & 65 & 72 & 77 & 84 & 90 & 97 & \begin{tabular}{|l|}
104 \\
\end{tabular} & 105 & 2 & 8 & 14 & 19 & 21 & 26 & 35 & 40 & 41 & 46 & 53 & 56 \\
\hline Аг изюм & 1 & 5 & 10 & 15 & 22 & 27 & 32 & 38 & 43 & 50 & 55 & 60 & 67 & 71 & 77 & 85 & 90 & 96 & 100 & 105 & 1 & 9 & 12 & 19 & 25 & 28 & 31 & 37 & 44 & 48 & 55 & \\
\hline ккерманский ч & 1 & 3 & 8 & 16 & 20 & 24 & 32 & 36 & 41 & 48 & 54 & 62 & 65 & 70 & 82 & 83 & 92 & 97 & 103 & 107 & t & 9 & 11 & 17 & 21 & 28 & 35 & 40 & 41 & 48 & 52 & 59 \\
\hline Аклык желтый & 1 & 5 & 8 & 14 & 20 & 24 & 32 & 36 & 40 & 47 & 55 & 61 & 67 & 72 & 77 & 83 & 91 & 96 & 101 & 105 & 5 & 9 & 14 & 19 & 21 & 28 & 33 & 37 & 41 & 47 & 55 & 59 \\
\hline Аленький & 2 & 3 & 8 & 17 & 22 & 25 & 32 & 37 & 42 & 47 & 55 & 60 & 64 & 71 & 82 & 83 & 92 & 96 & \begin{tabular}{|l|}
101 \\
\end{tabular} & \begin{tabular}{|l|}
105 \\
\end{tabular} & 1 & 9 & 11 & 16 & 21 & 28 & 31 & 36 & 41 & 46 & 52 & 58 \\
\hline Алый терский & 1 & 6 & 12 & 14 & 20 & 27 & 34 & 38 & 43 & 49 & 55 & 60 & 65 & 71 & 81 & 83 & 92 & 98 & 102 & \begin{tabular}{|l|}
107 \\
\end{tabular} & 4 & 9 & 12 & 17 & 24 & 28 & 34 & 37 & 44 & 47 & 53 & \\
\hline Амет аджи ибрам & 1 & 3 & 9 & 14 & 18 & 24 & 32 & 36 & 40 & 52 & 55 & 61 & 65 & 71 & 77 & 83 & 92 & 97 & 103 & 105 & 1 & 6 & 14 & 17 & 21 & 26 & 33 & 40 & 41 & 46 & 51 & 56 \\
\hline Асма & 1 & 7 & 9 & 14 & 21 & 23 & 32 & 37 & 41 & 45 & 57 & 62 & 67 & 75 & 82 & 83 & 90 & 99 & $\mid 104$ & 107 & 4 & 9 & 15 & 20 & 24 & 27 & 33 & 39 & 43 & 46 & 51 & 56 \\
\hline Баят капы & 1 & 7 & 11 & 14 & 22 & 25 & 32 & 37 & 42 & T & 57 & 3 & 65 & 71 & 81 & 88 & 92 & 96 & 101 & 107 & 2 & 6 & 12 & 19 & 21 & 26 & 33 & 39 & 41 & 49 & 55 & 59 \\
\hline Богос зерв & 1 & 4 & 8 & 16 & 18 & 25 & 31 & 38 & 42 & 52 & 55 & 2 & 64 & 71 & 77 & 83 & 92 & 96 & 103 & 105 & 2 & 6 & 15 & 20 & 21 & 26 & 35 & 40 & 44 & 49 & 51 & 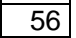 \\
\hline Бор кара & 1 & 7 & 11 & 13 & 18 & 27 & 32 & 38 & 43 & 51 & 57 & 61 & 65 & 71 & 81 & 83 & 92 & 98 & 101 & 107 & 1 & 7 & 14 & 17 & 21 & 30 & 34 & 39 & 44 & 48 & 51 & 56 \\
\hline Борю & 1 & 6 & 11 & 13 & 18 & 25 & 29 & 37 & 42 & 47 & 55 & 61 & 65 & 71 & 77 & 83 & 90 & 96 & \begin{tabular}{|l|}
101 \\
\end{tabular} & \begin{tabular}{|l|}
105 \\
\end{tabular} & 5 & 9 & 12 & 16 & 21 & 28 & 33 & 36 & 41 & 47 & 52 & 58 \\
\hline Брусковат & 2 & 3 & 8 & 17 & 22 & 25 & 32 & 27 & 41 & 45 & 54 & 60 & 64 & 71 & 82 & 83 & 92 & 96 & 101 & 105 & & 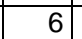 & 11 & 17 & 21 & 26 & 31 & 37 & 41 & 46 & 52 & 59 \\
\hline Будай шули & 1 & 7 & 12 & 14 & 21 & 27 & 32 & 38 & 43 & 51 & 57 & 61 & 67 & 75 & 77 & 85 & 91 & 98 & $\mid 102$ & 106 & & 7 & 14 & 17 & 21 & 27 & 34 & 37 & 45 & 49 & 52 & 56 \\
\hline Буланый бел & 1 & 4 & 9 & 16 & 21 & 25 & 32 & 7 & 41 & 45 & 55 & 61 & 64 & 70 & 77 & 83 & 91 & 96 & \begin{tabular}{|l|}
101 \\
\end{tabular} & 107 & 1 & \begin{tabular}{l|l}
6 \\
\end{tabular} & 11 & 19 & 21 & 26 & 35 & 39 & 41 & 49 & 51 & 56 \\
\hline पays & 1 & 6 & 10 & 13 & 18 & 27 & 32 & 38 & 43 & 46 & 56 & 61 & 66 & 71 & 77 & 85 & 90 & 97 & \begin{tabular}{|l|}
102 \\
\end{tabular} & 107 & 1 & $8 \mid$ & 12 & 17 & 24 & 27 & 31 & 38 & 44 & 49 & 52 & 59 \\
\hline Чол бер & 2 & 6 & 11 & 13 & 20 & 24 & 31 & 0 & 41 & 45 & 57 & 1 & 67 & 71 & 81 & 83 & 91 & 98 & 102 & 105 & & & 11 & 16 & 21 & 27 & 34 & 39 & 44 & 49 & 52 & 56 \\
\hline Чоркуца & 1 & 6 & 11 & 13 & 21 & 27 & 31 & 20 & 43 & 52 & 55 & 1 & 64 & 71 & 78 & 85 & 92 & 97 & \begin{tabular}{|l|}
103 \\
\end{tabular} & 107 & 2 & 9 & 11 & 16 & 21 & 26 & 31 & 40 & 41 & 46 & 52 & 00 \\
\hline Демир & 1 & 4 & 9 & 16 & 21 & \begin{tabular}{|l|}
27 \\
\end{tabular} & 31 & 38 & 41 & 47 & 55 & 62 & 65 & 70 & 82 & 87 & 92 & 96 & \begin{tabular}{|l|}
103 \\
\end{tabular} & 105 & 4 & 8 & 12 & 19 & 21 & 30 & 33 & 39 & 41 & 47 & 51 & 56 \\
\hline Док & 1 & 7 & 9 & 13 & 18 & 27 & 29 & 38 & 43 & $4 !$ & 57 & 61 & 66 & 72 & 77 & 83 & 90 & 98 & \begin{tabular}{|l|}
102 \\
\end{tabular} & 105 & & 7 & 12 & 20 & 25 & 28 & 31 & 36 & 44 & 47 & 53 & $x$ \\
\hline Дубут & 1 & 7 & 11 & 14 & 19 & 24 & 31 & 3 & 41 & 52 & 57 & 61 & 67 & 71 & 77 & 85 & 90 & 98 & \begin{tabular}{|l|}
101 \\
\end{tabular} & 107 & & 2 & 12 & 19 & 21 & 30 & 31 & 36 & 4 & 46 & 53 & 59 \\
\hline Джагар & 1 & 7 & \begin{tabular}{|l|}
12 \\
\end{tabular} & 13 & 19 & 27 & 31 & 3 & 43 & 47 & 57 & 61 & 67 & 71 & 78 & 83 & 91 & 98 & \begin{tabular}{|l|}
102 \\
\end{tabular} & 107 & 20 & 7 & 12 & 17 & 24 & 30 & 33 & 36 & 44 & 46 & 53 & 59 \\
\hline Джев & 1 & 4 & 10 & 16 & 18 & 25 & 33 & 37 & 41 & 52 & 55 & 61 & 65 & 71 & 81 & 83 & 92 & 97 & 103 & 105 & 1 & 6 & 14 & 19 & 21 & 28 & 31 & 37 & 43 & 49 & 52 & 56 \\
\hline Джунг & 2 & 6 & 12 & 13 & 21 & 27 & 29 & 38 & 42 & 45 & 56 & 61 & 67 & 71 & 77 & 83 & 90 & 98 & \begin{tabular}{|l|}
102 \\
\end{tabular} & 107 & & 8 & 12 & 16 & 21 & 26 & 31 & 38 & 41 & 46 & 53 & 55 \\
\hline Дi & 2 & 4 & 9 & 13 & 21 & \begin{tabular}{|l|}
25 \\
\end{tabular} & \begin{tabular}{|l|}
34 \\
\end{tabular} & 37 & 41 & 52 & 55 & 2 & 65 & 71 & 77 & 83 & 92 & 97 & \begin{tabular}{|l|}
104 \\
\end{tabular} & 105 & 1 & 9 & 12 & 16 & 25 & 30 & 33 & 39 & 44 & 47 & 51 & 56 \\
\hline $\mathrm{Ed}$ & 1 & 7 & 8 & 15 & 21 & 27 & 32 & 38 & 43 & 51 & 56 & 60 & 67 & 71 & 77 & 83 & 90 & 95 & 100 & \begin{tabular}{|l|}
107 \\
\end{tabular} & 1 & 6 & 11 & 16 & 25 & 28 & 34 & 38 & 1 & 46 & 52 & 58 \\
\hline Eqp & 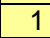 & 5 & 8 & 14 & 20 & 24 & 32 & 38 & 43 & 5 & 55 & 60 & 65 & 71 & 77 & 83 & 92 & 96 & \begin{tabular}{|l|}
100 \\
\end{tabular} & 105 & & $\pi$ & 11 & 17 & 21 & 27 & 35 & 40 & 41 & 49 & 51 & 56 \\
\hline Эмче & 1 & 6 & 11 & 13 & \begin{tabular}{|l|}
19 \\
\end{tabular} & 25 & 33 & 38 & 42 & $4 S$ & 55 & 60 & 67 & 73 & 77 & 83 & 90 & 97 & \begin{tabular}{|l|}
101 \\
\end{tabular} & 105 & 4 & 8 & 12 & 17 & 25 & 28 & 31 & 37 & 44 & 47 & 53 & $5 \varepsilon$ \\
\hline Галабура & 1 & 4 & 10 & 14 & 21 & 24 & 29 & 36 & 41 & 48 & 57 & 62 & 67 & 72 & 77 & 83 & 92 & 94 & $|100|$ & 105 & 1 & 7 & 14 & 17 & 21 & 26 & 31 & 36 & 41 & 46 & 51 & 56 \\
\hline Генде & 1 & 6 & 10 & 14 & 21 & 27 & 29 & 3 & 43 & & 55 & 63 & 65 & 71 & 82 & 8 & 92 & 98 & 103 & 105 & & 7 & 15 & 19 & 24 & 28 & & & & 48 & 51 & $3 x$ \\
\hline Гок & 1 & 7 & 11 & 14 & 21 & 28 & 32 & 38 & 43 & $4 \mathrm{C}$ & 57 & 61 & 65 & 71 & 82 & 83 & 92 & 97 & 101 & 106 & & 7 & 12 & 17 & 21 & 26 & 33 & 37 & 43 & 47 & 52 & 56 \\
\hline Гюль & 1 & 6 & 10 & 15 & 21 & 27 & 32 & 3 & 4 & 4 & 55 & 1 & 66 & 71 & 77 & 85 & 91 & 99 & $\mid 104$ & 107 & 5 & 9 & 12 & 17 & 24 & 28 & 33 & 37 & 44 & 47 & 53 & 58 \\
\hline Гюля & 1 & 6 & 11 & 16 & 20 & 27 & 32 & 3 & 4 & & 55 & 61 & 66 & 71 & 78 & 85 & 91 & 99 & \begin{tabular}{|l|}
104 \\
\end{tabular} & 107 & & 9 & 12 & 16 & 21 & 28 & 31 & 3 & 41 & 47 & 55 & $5 \mathrm{~s}$ \\
\hline & 2 & 6 & 12 & $\mid 13$ & 20 & 27 & 32 & 3 & 41 & & 5 & 63 & 65 & t & 78 & 33 & 90 & 98 & \begin{tabular}{|l|}
104 \\
\end{tabular} & 10 & & 9 & & 17 & 21 & 27 & 33 & 36 & & 46 & 53 & -7 \\
\hline Кабассия & 1 & 6 & 10 & 13 & 19 & 24 & 32 & 36 & 40 & 53 & 57 & 63 & 67 & 76 & 80 & 83 & 91 & 97 & 101 & 107 & 4 & 9 & 11 & 17 & 21 & 28 & 33 & 40 & 41 & 49 & 52 & 56 \\
\hline Кайтаги & 2 & 7 & 12 & 14 & 21 & 24 & 32 & 36 & 40 & 48 & 55 & 60 & 67 & 72 & 78 & 83 & 91 & 98 & 101 & 107 & 2 & 8 & 12 & 17 & 21 & 28 & 35 & 39 & 3 & 46 & 53 & 59 \\
\hline Канд & 1 & 4 & 9 & 16 & \begin{tabular}{|l|}
19 \\
\end{tabular} & 25 & 32 & 37 & 42 & & 55 & & 65 & 7 & 77 & 83 & 92 & 98 & 101 & 107 & & 8 & 14 & 19 & 21 & 28 & 31 & 40 & & 48 & 53 & 55 \\
\hline & 1 & 5 & 10 & 16 & 18 & 25 & 30 & 3 & 42 & & 55 & & 65 & & 81 & 83 & 90 & 95 & \begin{tabular}{|l|}
100 \\
\end{tabular} & 10 & & 6 & & & 21 & 26 & 31 & 40 & & 49 & 51 & 56 \\
\hline Хади туму & 1 & 5 & 9 & 13 & 18 & 24 & 32 & 37 & 42 & 50 & 55 & 61 & 67 & 74 & 77 & 85 & 90 & 95 & \begin{tabular}{|l|}
101 \\
\end{tabular} & \begin{tabular}{|l|}
107 \\
\end{tabular} & 1 & 9 & 12 & 16 & 24 & 30 & 31 & 38 & 43 & 46 & 53 & 58 \\
\hline Халиль изю & 1 & 5 & 11 & 16 & 20 & 27 & 32 & 38 & 42 & 52 & 55 & 1 & 65 & 71 & 77 & 83 & 91 & 96 & 103 & 105 & 5 & 8 & 15 & 19 & 21 & 28 & 31 & 40 & 43 & 46 & 52 & 56 \\
\hline Харко & 1 & 5 & 9 & 15 & 19 & 24 & 32 & 36 & 41 & 51 & 56 & 01 & 65 & 71 & 77 & 83 & 92 & 96 & 102 & 105 & & 6 & 111 & 19 & 21 & 26 & 35 & 39 & 41 & 49 & 51 & 56 \\
\hline Хатал-баар & 2 & 5 & 12 & 15 & 18 & 24 & 32 & 36 & 41 & 53 & 57 & 60 & 66 & 71 & 81 & 89 & 90 & 97 & 100 & 105 & 1 & 9 & 14 & 19 & 21 & 27 & 35 & 39 & 45 & 48 & 51 & 56 \\
\hline
\end{tabular}

http://ej.kubagro.ru/2016/07/pdf/03.pdf 
4.3. Синтез и верификация информационной модели, отражающей количество информации в генах о фенотипических свойствах (многопараметрическая типизация)

После формализации предметной области запускаем режим 3.5, обеспечивающий синтез и верификацию моделей с параметрами, приведенными на рисунке 5.

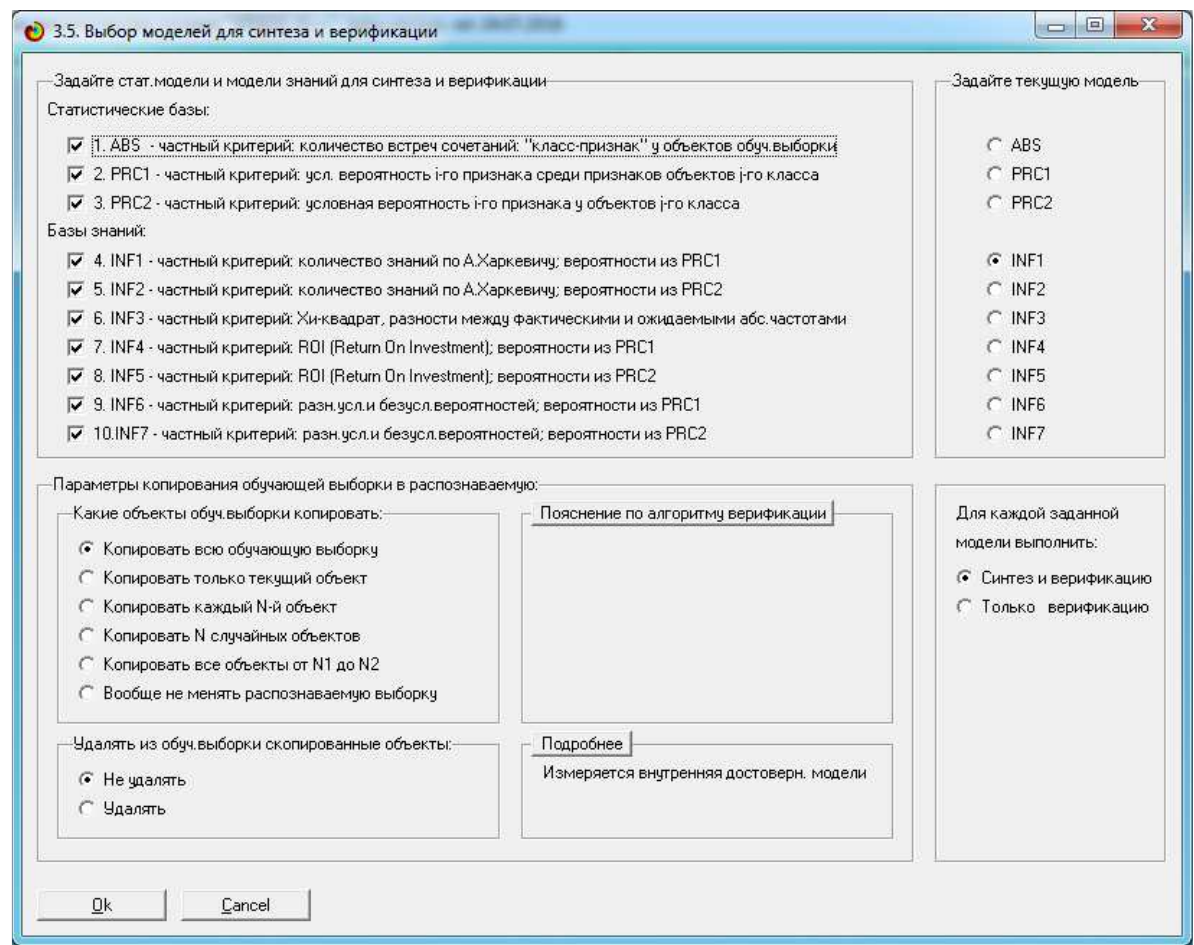

Рисунок 5. Окно запуска режима синтеза и верификации модели (3.5)

Частные модели ABS, PRC\#, INF\#, отличаются друг друга частными критериями знаний $[8,9]$ (таблица 7).

Таблица 7 - Частные критерии знаний, используемые в настоящее время в АСК-анализе и системе «Эйдос-X++»

\begin{tabular}{|l|c|c|}
\hline \multicolumn{1}{|c|}{\begin{tabular}{c}
\multicolumn{1}{|c|}{$\begin{array}{c}\text { Наименование модели знаний } \\
\text { и частный критерий }\end{array}$} \\
\cline { 2 - 3 }
\end{tabular}} & $\begin{array}{c}\text { Выражение для частного критерия } \\
\text { относительные ча- } \\
\text { стоты }\end{array}$ & $\begin{array}{c}\text { через } \\
\text { абсолютные частоты }\end{array}$ \\
\hline $\begin{array}{l}\text { INF1, частный критерий: количество знаний } \\
\text { по А.Харкевичу, 1-й вариант расчета относи- } \\
\text { тельных частот: } N j \text { - суммарное количество } \\
\text { признаков по j-му классу. Относительная } \\
\text { частота того, что если у объекта ј-го класса } \\
\text { обнаружен признак, то это і-й признак }\end{array}$ & $I_{i j}=\Psi \times \log _{2} \frac{P_{i j}}{P_{i}}$ & $I_{i j}=\Psi \times \log _{2} \frac{N_{i j} N}{N_{i} N_{j}}$ \\
\hline $\begin{array}{l}\text { INF2, частный критерий: количество знаний } \\
\text { по А.Харкевичу, 2-й вариант расчета относи- } \\
\text { тельных частот: } N j-\text { суммарное количество }\end{array}$ & $I_{i j}=\Psi \times \log _{2} \frac{P_{i j}}{P_{i}}$ & $I_{i j}=\Psi \times \log _{2} \frac{N_{i j} N}{N_{i} N_{j}}$ \\
\hline
\end{tabular}




\begin{tabular}{|c|c|c|}
\hline $\begin{array}{l}\text { объектов по j-му классу. Относительная ча- } \\
\text { стота того, что если предъявлен объект ј-го } \\
\text { класса, то у него будет обнаружен і-й при- } \\
\text { знак. }\end{array}$ & & \\
\hline $\begin{array}{l}\text { INF3, частный критерий: Хи-квадрат: разно- } \\
\text { сти между фактическими и теоретически } \\
\text { ожидаемыми абсолютными частотами }\end{array}$ & --- & $I_{i j}=N_{i j}-\frac{N_{i} N_{j}}{N}$ \\
\hline $\begin{array}{l}\text { INF4, частный критерий: ROI - Return On } \\
\text { Investment, 1-й вариант расчета относитель- } \\
\text { ных частот: } \mathrm{Nj} \text { - суммарное количество при- } \\
\text { знаков по } j \text {-му классу }\end{array}$ & $I_{i j}=\frac{P_{i j}}{P_{i}}-1=\frac{P_{i j}-P_{i}}{P_{i}}$ & $I_{i j}=\frac{N_{i j} N}{N_{i} N_{j}}-1$ \\
\hline $\begin{array}{l}\text { INF5, частный критерий: ROI - Return On } \\
\text { Investment, 2-й вариант расчета относитель- } \\
\text { ных частот: } N j \text { - суммарное количество объ- } \\
\text { ектов по } j \text {-му классу }\end{array}$ & $I_{i j}=\frac{P_{i j}}{P_{i}}-1=\frac{P_{i j}-P_{i}}{P_{i}}$ & $I_{i j}=\frac{N_{i j} N}{N_{i} N_{j}}-1$ \\
\hline $\begin{array}{l}\text { INF6, частный критерий: разность условной } \\
\text { и безусловной относительных частот, } 1 \text {-й } \\
\text { вариант расчета относительных частот: } N j- \\
\text { суммарное количество признаков по } j \text {-му } \\
\text { классу }\end{array}$ & $I_{i j}=P_{i j}-P_{i}$ & $I_{i j}=\frac{N_{i j}}{N_{j}}-\frac{N_{i}}{N}$ \\
\hline $\begin{array}{l}\text { INF7, частный критерий: разность условной } \\
\text { и безусловной относительных частот, } 2 \text {-й } \\
\text { вариант расчета относительных частот: } N j- \\
\text { суммарное количество объектов по } j \text {-му } \\
\text { классу }\end{array}$ & $I_{i j}=P_{i j}-P_{i}$ & $I_{i j}=\frac{N_{i j}}{N_{j}}-\frac{N_{i}}{N}$ \\
\hline
\end{tabular}

Обозначения:

$i$ - значение прошлого параметра;

$j$ - значение будущего параметра;

$N_{i j}$ - количество встреч j-го значения будущего параметра при $i$-м значении прошлого параметра;

M - суммарное число значений всех прошлых параметров;

$W$ - суммарное число значений всех будущих параметров;

$N_{i}$ - количество встреч i-м значения прошлого параметра по всей выборке;

$N_{j}$ - количество встреч j-го значения будущего параметра по всей выборке;

$N$ - количество встреч $j$-го значения будущего параметра при $i$-м значении прошлого параметра по всей выборке;

$I_{i j}$ - частный критерий знаний: количество знаний в факте наблюдения i-го значения прошлого параметра о том, что объект перейдет в состояние, соответствующее ј-му значению будущего параметра;

$\Psi$ - нормировочный коэффициент (Е.В. Луцеенко, 2002), преобразующий количество информащии в формуле А.Харкевича в биты и обеспечивающий для нее соблюдение принципа соответствия с формулой Р.Хартли;

$P_{i}$ - безусловная относительная частота встречи $i$-го значения прошлого параметра в обучающей выборке;

$P_{i j}-$ условная относительная частота встречи $i$-го значения прошлого параметра при ј-м значении будущего параметра.

\footnotetext{
${ }^{5}$ Применение предложено Л.О. Макаревич
} 
Все эти способы метризации с применением 7 частных критериев знаний (таблица 7) реализованы в системно-когнитивном анализе и интеллектуальной системе «Эйдос» и обеспечивают сопоставление градациям всех видов шкал числовых значений, имеющих смысл количества информации в градации о принадлежности объекта к классу. Поэтому является корректным применение интегральных критериев, включающих операции умножения и суммирования, для обработки числовых значений, соответствующих градациям шкал. Это позволяет единообразно и сопоставимо обрабатывать эмпирические данные, полученные с помощью любых типов шкал, применяя при этом все математические операции.

На рисунке 6 приведено окно с отображением процесса исполнения режима 3.5. Из этого рисунка видно, что синтез и верификация модели была выполнена за 6 минут 48 секунд (процессор i7). Отметим, что встречаются задачи интеллектуальной обработки больших данных, в которых этот режим может выполняться неделю и даже более.

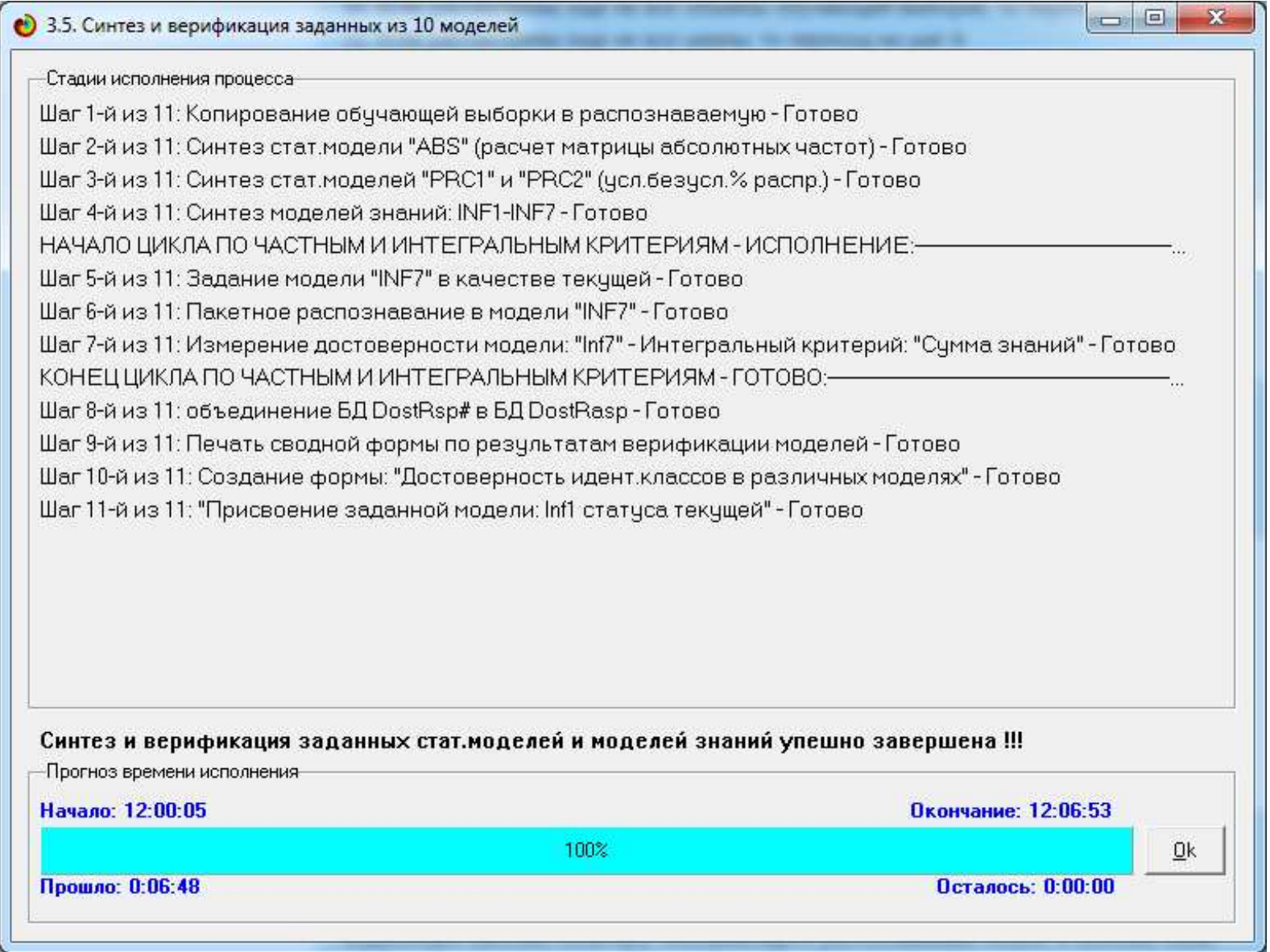

Рисунок 6. Отображение стадии исполнения режима 3.5.

Достоверность идентификации и не идентификации объектов обучающей выборки в созданных моделях приведена в экранной форме режима 4.1.3.6 (рисунок 7): 


\begin{tabular}{|c|c|c|c|c|c|c|c|}
\hline \multicolumn{6}{|c|}{ (0) 4.1.3.6. Обобщ.форма по достов.моделей при разн.инт.крит.. Текущая модель: "INF1" } & \multicolumn{2}{|c|}{\begin{tabular}{|l|l|l|}
0 & 回 & $x$ \\
\end{tabular}} \\
\hline Наименование модели и частного критерия & Интегральный критерий & $\begin{array}{l}\text { Вероятность } \\
\text { правильнои } \\
\text { идентифка.. }\end{array}$ & $\begin{array}{l}\text { Вероятность } \\
\text { правильной } \\
\text { не ияентиф. }\end{array}$ & \begin{tabular}{|l|} 
Средняя \\
веролтно.. \\
правильн... \\
результата
\end{tabular} & \begin{tabular}{|l} 
Дата \\
получения \\
результата
\end{tabular} & \begin{tabular}{|l|} 
Время \\
получения \\
результ...
\end{tabular} & 박 \\
\hline & Корреляция абс. частот с обр.... & 100.000 & 0.058 & 50.029 & 25.07 .2016 & $12: 01: 25$ & \\
\hline 1. ABS - частный критерий: количество встреч сочетаний: "клас... & Сумма абс. частот по признак... & 100.000 & & 50.000 & 25.07 .2016 & $12: 01: 25$ & \\
\hline 2. PRC1 - частный критерий: усл. вероятность і-го признака сред... & Корреляция усл. отн. частот с о... & 100.000 & 0.058 & 50.029 & 25.07 .2016 & $12: 02: 02$ & \\
\hline 2. PRC1 - частный критерий: усл. вероятность і-го признака сред... & Сумма усл.отн. частот по приз... & 100.000 & & 50.000 & 25.07 .2016 & $12: 02: 02$ & \\
\hline 3. PRC2 - частный критерий: условная вероятность і-го признака... & Коррелящия усл. отн. частот с о... & 100.000 & 0.058 & 50.029 & 25.07 .2016 & $12: 02: 39$ & \\
\hline 3. PRC2 - частный критерий: условная вероятность і-го признака... & Сумма усл.отн. частот по приз... & 100.000 & & 50.000 & 25.07 .2016 & $12: 02: 39$ & \\
\hline 4. INF1 - частный критерий: количество знаний по А.Харкевичу; в... & Семантический резонанс зна... & 90.112 & 79.241 & 84.677 & 25.07 .2016 & $12: 03: 15$ & \\
\hline 4. INF1 - частный критерий: количество знаний по А.Харкевичу; в... & Сумма знаний & 82.022 & 84.325 & 83.174 & 25.07 .2016 & $12: 03: 15$ & \\
\hline 5. INF2 - частный критерий: количество знаний по А. Харкевичу; в... & Семантический резонанс зна... & 90.169 & 79.098 & 84.633 & 25.07 .2016 & $12: 03: 51$ & \\
\hline 5. INF2 - частный критерий: Количество знаний по А.Харкевичу; В... & Сумма знаний & 80.674 & 83.307 & 81.990 & 25.07 .2016 & $12: 03: 51$ & \\
\hline 6. INF3 - частный критерий: Хи-Квадрат, разности между фактич... & Семантический резонанс зна... & 91.011 & 72.787 & 81.899 & 25.07 .2016 & $12: 04: 28$ & \\
\hline 6. INF3 - частный критерий: Хи-Квадрат, разности между фактич... & Сумма знаний & 91.011 & 72.787 & 81.899 & 25.07 .2016 & $12: 04: 28$ & \\
\hline 7. INF4 - частный критерий: ROI (Return On Investment); вероятно... & Семантический резонанс зна... & 89.101 & 81.296 & 85.198 & 25.07 .2016 & $12: 05: 04$ & \\
\hline 7. INF4 - частный критерий: ROI (Return On Investment); вероятно... & Сумма знаний & 92.640 & 66.270 & 79.455 & 25.07 .2016 & $12: 05: 04$ & \\
\hline 8. INF5 - частный критерий: ROI (Return On Investment); вероятно... & Семантический резонанс зна... & 87.809 & 80.885 & 84.347 & 25.07 .2016 & $12: 05: 40$ & \\
\hline 8. INF5 - частный критерий: ROI (Return On Investment); вероятно... & Сумма знаний & 91.292 & 65.658 & 78.475 & 25.07 .2016 & $12: 05: 40$ & \\
\hline 9. INF6 - частный критерий: разн.усл.и безусл.вероятностей; вер... & Семантический резонанс зна... & 90.225 & 72.915 & 81.570 & 25.07 .2016 & $12: 06: 16$ & \\
\hline 9. INF6 - частный критерий: разн.усл.и безусл.вероятностей; вер... & Сумма знаний & 91.011 & 66.401 & 78.706 & 25.07 .2016 & $12: 06: 16$ & \\
\hline 10.INF7 - частный критерий: разн.усл.и безусл.вероятностей; ве... & Семантический резонанс зна... & 89.213 & 72.689 & 80.951 & 25.07 .2016 & $12: 06: 52$ & \\
\hline 10.INF7 - частный критерий: разн.усл.и безусл.вероятностей; ве... & Сумма знаний & 88.202 & 65.564 & 76.883 & 25.07 .2016 & $12: 06: 52$ & - \\
\hline \multicolumn{8}{|c|}{ I. } \\
\hline
\end{tabular}

Рисунок 7. Достоверность идентификации и не идентификации объектов обучающей выборки в созданных моделях

Для оценки достоверности моделей используется предложенная проф. Е.В. Луценко метрика, сходная с известным F-критерием (рисунок 8):

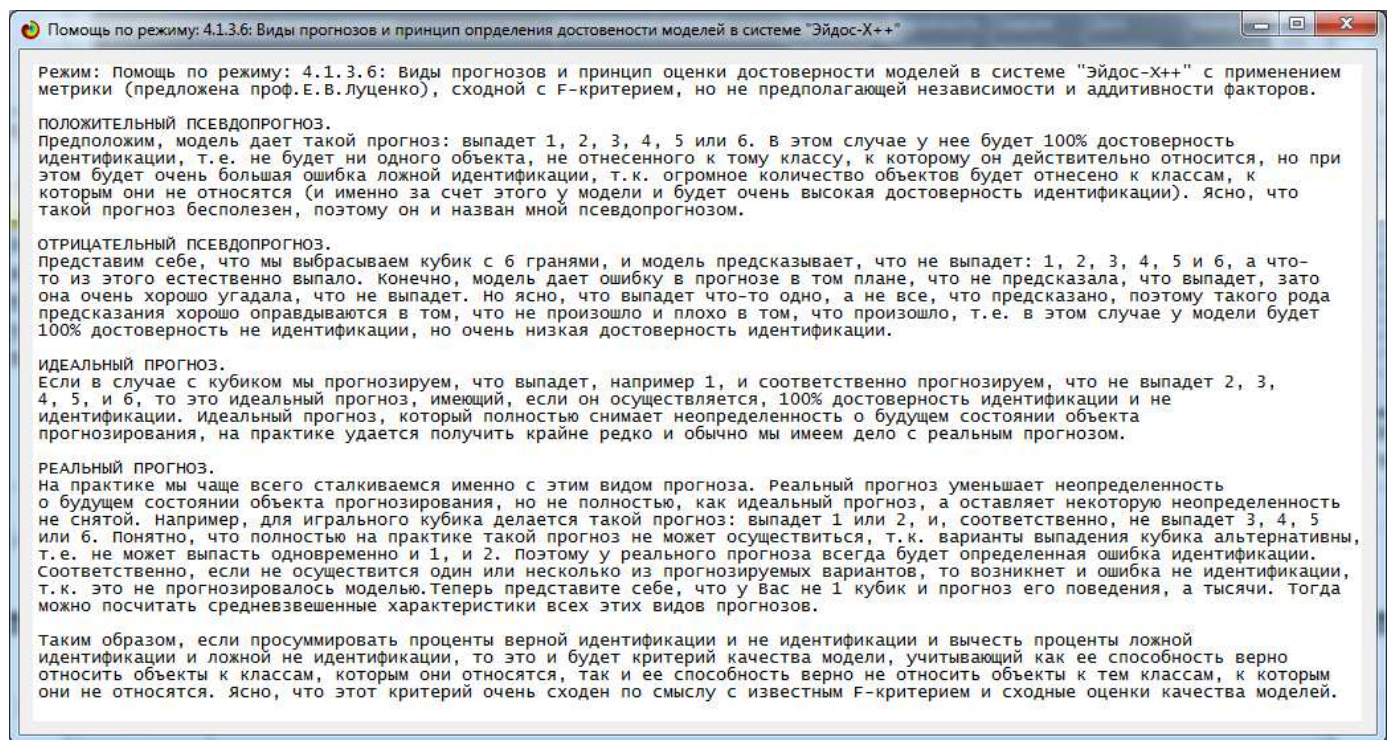

Рисунок 8. Оценка достоверности моделей в системе «Эйдос»

Ниже, на рисунках 9 приведены фрагменты моделей, отражающих взаимосвязи между структурой генома и фенотипическими признаками и свойствами винограда, отличающихся частными критериями знаний $[8,9]$ (экранные формы получены в режиме 5.5, названия моделей приведены на экранных формах). 


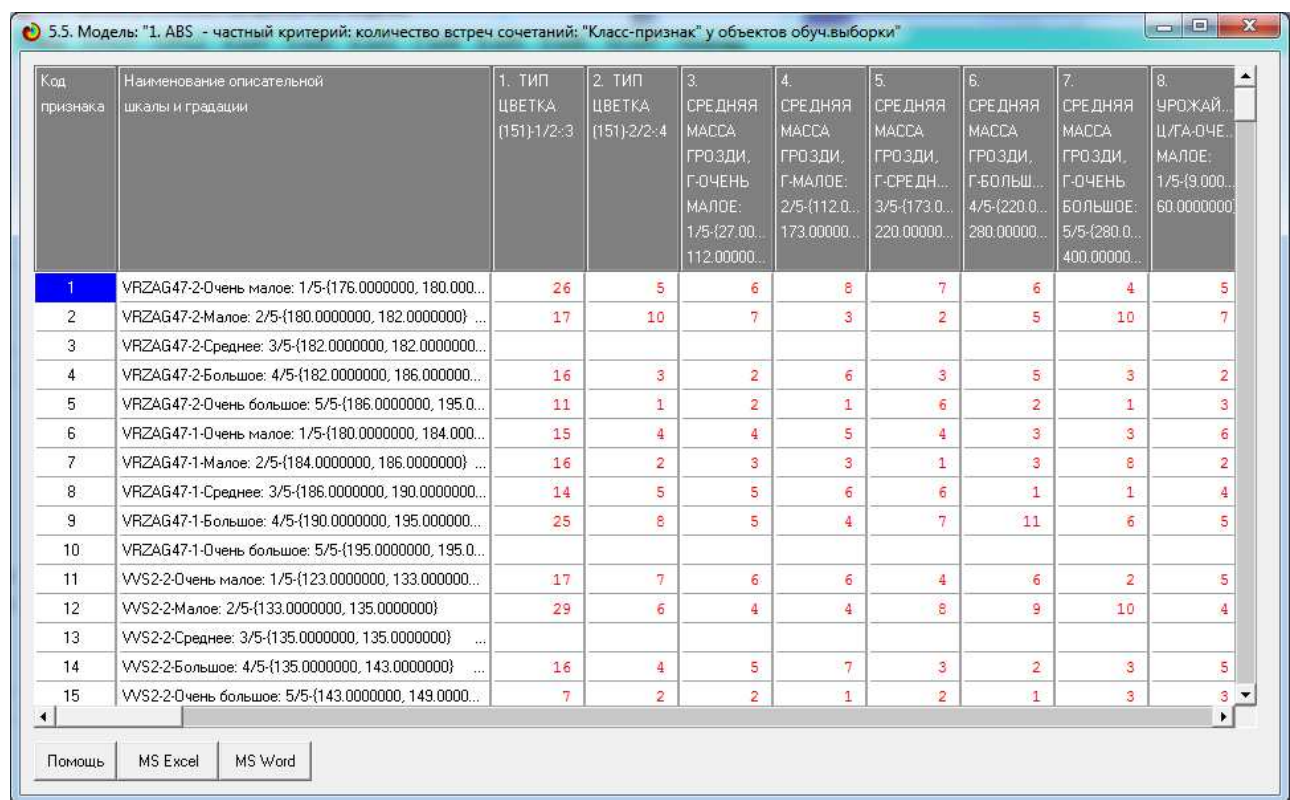

\begin{tabular}{|l|l|l|l|}
\hline (7) 5.5. Модель: "3. PRC2 - частный критерий: условная вероятность і-го признака у объектов ј-го класса" & 回 \\
\hline
\end{tabular}

\begin{tabular}{|c|c|c|c|c|c|c|c|c|c|c|}
\hline $\begin{array}{l}\text { Kog } \\
\text { nрuннaka }\end{array}$ & $\begin{array}{l}\text { Наименование описательной } \\
\text { шкалы и градаиии. }\end{array}$ & \begin{tabular}{|l|} 
1. ТИП \\
LВETKA \\
(151)-1/2-3
\end{tabular} & \begin{tabular}{|l|} 
2. ТИП \\
LВETKA \\
(151):2/2:4
\end{tabular} & 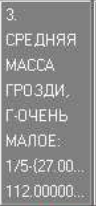 & 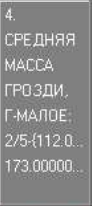 & \begin{tabular}{|l|}
5. \\
CРЕДНЯЯ \\
MАССА \\
ГPOЗДИ. \\
Г.СРЕДН... \\
$3 / 5: 173.0$. \\
220.00000. \\
\end{tabular} & 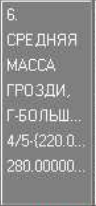 & \begin{tabular}{|l|}
7. \\
СРЕДНЯЯ \\
МАССА \\
ГРОЗДИ, \\
Г-ОЧЕНЬ \\
БОЛЬШОЕ: \\
$5 / 5.280 .0 .$. \\
400.00000. \\
\end{tabular} & 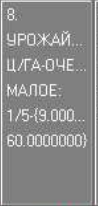 & $\begin{array}{l}4 . \\
2,1\end{array}$ \\
\hline 1 & |VRZAG477-2-0чень малое: $1 / 5$ \{1776.0000000, $180 .$. & 37.143 & 26.316 & 35.294 & 44.444 & 38.889 & 33.333 & 22.222 & 29.412 & \\
\hline 2 & VRZAG47-2-Maлое: $2 / 5-\{180.0000000,182.00000 \ldots$ & 24.286 & 52.632 & 41.176 & 16.667 & 11.111 & 27.778 & 55.556 & 41.176 & \\
\hline 3 & VRZAG47-2-Среднее: $3 / 5 \cdot\{182.0000000,182.000 \ldots$ & & & & & & & & & \\
\hline 4 & VRZAG477-2-Большое: 4/5-\{182.0000000, $186.000 \ldots$ & 22.857 & 15.789 & 11.765 & 33.333 & 16.667 & 27.778 & 16.667 & 11.765 & \\
\hline 5 & VRZAG477-2-0чень 6ольшое: $5 / 5 \cdot\{186.0000000,1 \ldots$ & 15.714 & 5.263 & 11.765 & 5.556 & 33.333 & 11.111 & 5.556 & 17.647 & \\
\hline 6 & VRZAG 47-1-0чень малое: $1 / 5 \cdot\{180.0000000,184 \ldots$ & 21.429 & 21.053 & 23.529 & 27.778 & 22.222 & 16.667 & 16.667 & 35.294 & \\
\hline 7 & VRZAGG7-1-Manoe: $2 / 5:\{184.0000000,186.00000 \ldots$ & 22.857 & 10.526 & 17.647 & 16.667 & 5.556 & 16.667 & 44.444 & 11.765 & \\
\hline 8 & VRZAG 47-1-Среднее: $3 / 5-\{186.0000000,190.000 \ldots$ & 20.000 & 26.316 & 29.412 & 33.333 & 33.333 & 5.556 & 5.556 & 23.529 & \\
\hline 9 & VRZAG47-1-Большое: 4/5-\{190.0000000, $195.000 \ldots$ & 35.714 & 42.105 & 29.412 & 22.222 & 38.889 & 61.111 & 33.333 & 29.412 & \\
\hline 10 & VRZAG47-1-0чень большое: $5 / 5-\{195.0000000,1 \ldots$ & & & & & & & & & \\
\hline 11 & WS2-2-0чень малое: $1 / 5-\{123.0000000,133.000$... & 24.286 & 36.842 & 35.294 & 33.333 & 22.222 & 33.333 & 11.111 & 29.412 & \\
\hline 12 & WS2-2-Maлое: $2 / 5\{133.0000000,135.0000000\}$ & 41.429 & 31.579 & 23.529 & 22.222 & 44.444 & 50.000 & 55.556 & 23.529 & \\
\hline 13 & WS2-2-Среднее: $3 / 5-\{135.0000000,135.0000000 \ldots$ & & & & & & & & & \\
\hline 14 & WS2-2.Большое: $4 / 5-\{135.0000000,143.000000 . .$. & 22.857 & 21.053 & 29.412 & 38.889 & 16.667 & 11.111 & 16.667 & 29.412 & \\
\hline$+\left.\right|^{15}$ & WS2-2.0 पеньь 6ольшое: $5 / 5-1143.0000000,149.0 \ldots$ & 10.000 & 10.526 & 11.765 & 5.556 & 11.111 & 5.556 & 16.667 & 17.647 & 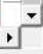 \\
\hline Помощь & MS Word & & & & & & & & & \\
\hline
\end{tabular}

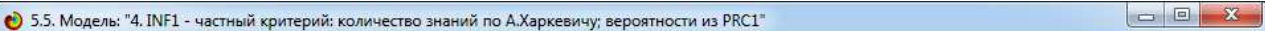

\begin{tabular}{|c|c|c|c|c|c|c|c|c|c|c|}
\hline $\begin{array}{l}\text { Kag } \\
\text { חризнакa }\end{array}$ & $\begin{array}{l}\text { Наименов ание опивательной } \\
\text { шкальі и градации }\end{array}$ & \begin{tabular}{|l|} 
1. ТИП \\
LBETKA \\
$(151) 1 / 2 \cdot 3$
\end{tabular} & \begin{tabular}{|l|} 
2. ТИП \\
ЦLBETKA \\
$(151 ; \cdot 2 / 2 \cdot 4$
\end{tabular} & 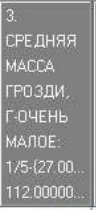 & 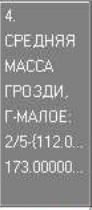 & \begin{tabular}{|l|}
5. \\
СРЕДНяЯ \\
MAССА \\
ГРОЗДИ. \\
Г.СРЕДН. \\
$3 / 5: 173.0$. \\
220.00000. \\
\end{tabular} & 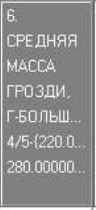 & \begin{tabular}{|l|}
7. \\
CРЕДНЯЯ \\
МАССА \\
ГРОЗДИ. \\
Г-ОЧЕНЬ \\
БОЛЬШОЕ: \\
5/5.1280.0... \\
400.00000... \\
\end{tabular} & 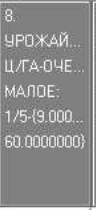 & $\begin{array}{l}9.4 \\
y \\
4 .-1\end{array}$ \\
\hline 1 & VRZAG47-2-0чень малое: $1 / 5-\{176.0000000,180 .$. & 0.041 & -0.179 & 0.006 & 0.138 & 0.089 & -0.023 & -0.285 & -0.074 & \\
\hline 2 & VRZAG47-2-Manoe: $2 / 5-\{180.0000000,182.00000 \ldots$ & -0.129 & 0.317 & 0.180 & -0.364 & -0.575 & -0.049 & 0.343 & 0.209 & \\
\hline 3 & VRZAG47-2-Среднее: $3 / 5-\{182.0000000,182.000 \ldots$ & & & & & & & & & \\
\hline 4 & VRZAGG47-2-Большое: 4/5-\{182.0000000, $186.000 \ldots$ & 0.044 & -0.191 & -0.357 & 0.258 & -0.124 & 0.160 & -0.165 & -0.328 & \\
\hline 5 & VRZAG477-2-0чень больштое: $5 / 5 \cdot\{186.0000000,1 \ldots$ & 0.094 & -0.572 & -0.083 & -0.536 & 0.563 & -0.112 & -0.545 & 0.187 & \\
\hline 6 & VRZAG 47-1-0чень малое: $1 / 5 \cdot\{180.0000000,184 \ldots$ & 0.005 & -0.020 & 0.056 & 0.149 & 0.047 & -0.144 & -0.165 & 0.327 & \\
\hline 7 & VRZAG47-1-Maлое: $2 / 5\{\{184.0000000,186.00000 \ldots$ & 0.076 & -0.401 & -0.083 & -0.123 & -0.746 & -0.112 & 0.452 & -0.296 & \\
\hline 8 & VRZAG 47-1-Среднее: $3 / 5 \cdot\{186.0000000,190.000 \ldots$ & -0.036 & 0.113 & 0.189 & 0.258 & 0.289 & -0.798 & -0.819 & 0.085 & \\
\hline 9 & VRZAG477-1-Бальшое: 4/5-\{190.0000000, $195.000 \ldots$ & -0.019 & 0.064 & -0.140 & -0.313 & 0.052 & 0.301 & -0.081 & -0.111 & \\
\hline 10 & VRZAG 477-1.04ень большое: $5 / 5-\{195.0000000,1 \ldots$ & & & & & & & & & \\
\hline 11 & WS2-2-0чень малое: $1 / 5-\{123.0000000,133.000 \ldots$ & -0.059 & 0.174 & 0.159 & 0.119 & -0.092 & 0.130 & -0.545 & 0.079 & \\
\hline 12 & WS2-2-Maлое: $2 / 5 \cdot\{133.0000000,135.0000000\}$ & 0.034 & -0.142 & -0.308 & -0.348 & 0.096 & 0.147 & 0.189 & -0.279 & \\
\hline 13 & WS2-2-Среднее: $3 / 5-\{135.0000000,135.0000000$. & & & & & & & & & \\
\hline 14 & WS2-2.5ольшое: $4 / 5 \cdot\{135.0000000,143.000000 .$. & 0.013 & -0.050 & 0.159 & 0.319 & -0.154 & -0.416 & -0.195 & 0.187 & \\
\hline$+\left.\right|^{15}$ & WS2-2.04ень большое: $5 / 5 \cdot 143.0000000,149.0 \ldots$ & -0.003 & 0.012 & 0.089 & -0.364 & 0.080 & -0.353 & 0.280 & 0.359 & 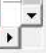 \\
\hline Помощь & MS Excel & & & & & & & & & \\
\hline
\end{tabular}




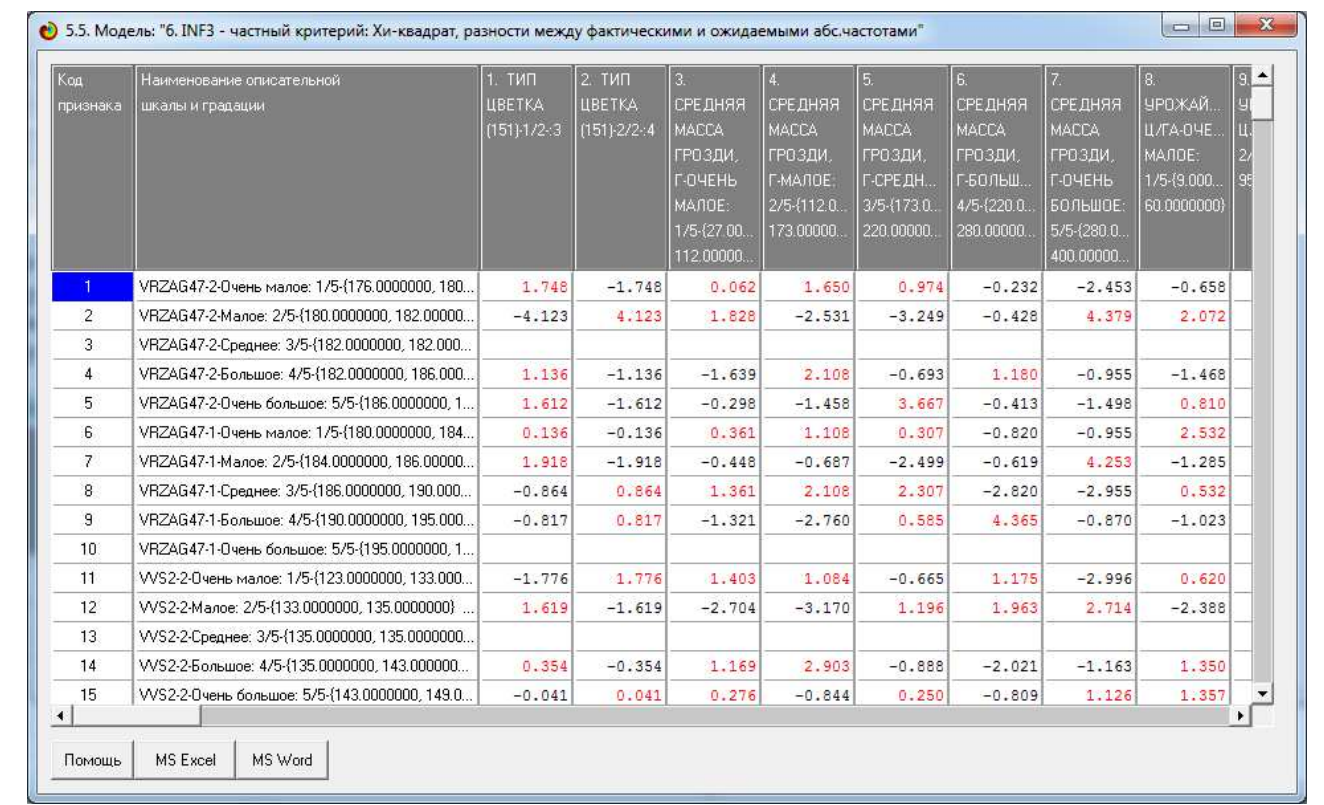

Рисунок 9. Фрагменты моделей, отражающих взаимосвязи между структурой генома и фенотипическими свойствами/признаками винограда

\section{4. Решение задачи системной идентификации феноти- пических признаков и свойств по наличию тех или иных ге- HOB}

Смысл этой задачи состоит в том, чтобы используя отраженные в моделях знания о силе и направлении влияния различных структур генома (степень выраженности генов на спиралях ДНК) на степень выраженности различных фенотипических признаков и свойств по описанию структур генома определить, какими фенотипическими признаками и свойствами будет обладать виноград с таким геномом.

В АСК-анализе и системе «Эйдос» эта задача решается двумя способами:

1) считается, что объект тем в большей степени относится к некоторому классу, чем больше информации о принадлежности к нему содержится в его признаках;

2) считается, что объект тем в большей степени относится к некоторому классу, чем больше его профиль по степени выраженности признаков сходен с профилем класса, в котором отражена степень характерности этих признаков для класса.

Первый способ соответствует применению интегрального критерия: «Сумма знаний», а второй - «Резонанс знаний».

Рассмотрим интегральные критерии знаний, используемые в настоящее время в АCК-анализе и системе «Эйдос-X++» для верификации мо- 
делей и решения задач идентификации и прогнозирования, а затем приведем некоторые выходные формы с результатами распознавания. Все их не приведем, т.к. их довольно много (рисунок 10):

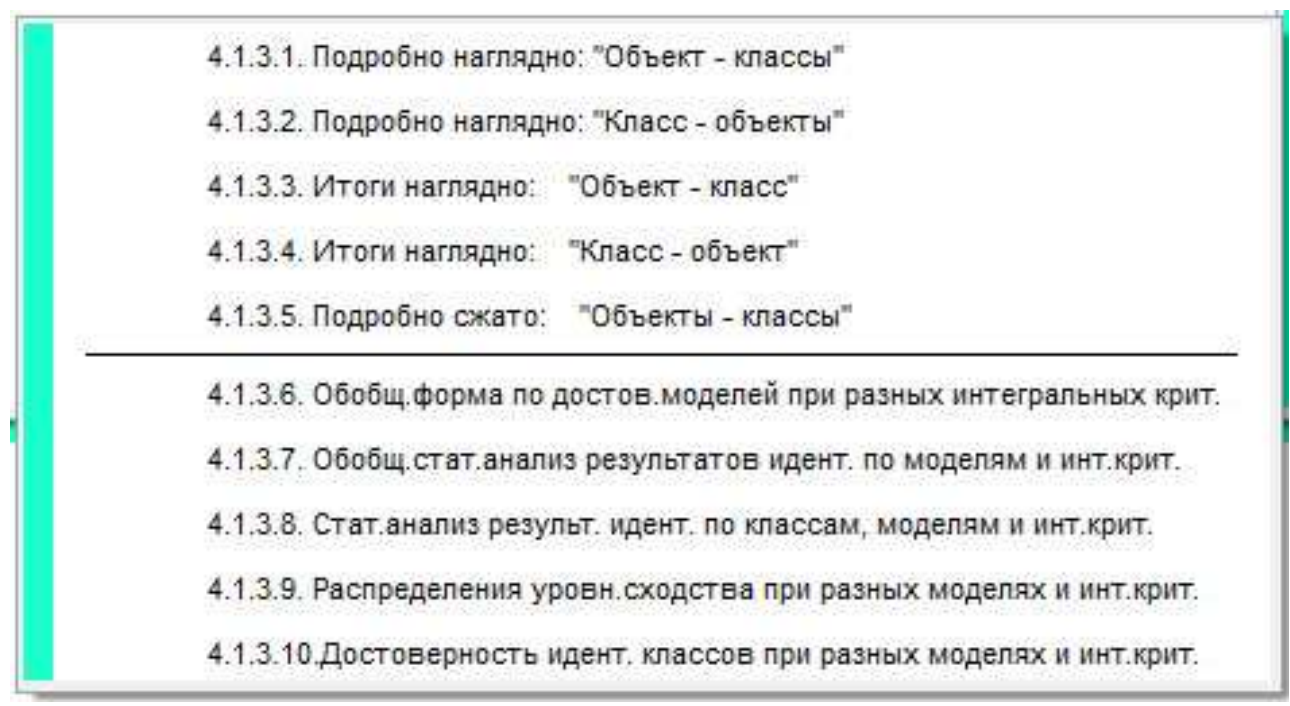

Рисунок 10. Формы с результатами распознавания системы «Эйдос»

\subsection{1. Интегральный критерий - «Сумма знаний»}

1-й интегральный критерий «Сумма знаний» представляет собой суммарное количество знаний, содержащееся в системе факторов различной природы, характеризующих сам объект управления, управляющие факторы и окружающую среду, о переходе объекта в будущие целевые или нежелательные состояния.

Интегральный критерий представляет собой аддитивную функцию от частных критериев знаний и имеет вид::

$$
I_{j}=\left(\vec{I}_{i j}, \vec{L}_{i}\right)
$$

В выражении круглыми скобками обозначено скалярное произведение. В координатной форме это выражение имеет вид:

$$
I_{j}=\sum_{i=1}^{M} I_{i j} L_{i},
$$

где: $M$ - количество градаций описательных шкал (признаков);

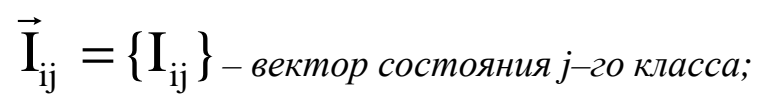

$\overrightarrow{\mathrm{L}}_{\mathrm{i}}=\left\{\mathrm{L}_{\mathrm{i}}\right\}$ - вектор состояния распознаваемого объекта, включающий все виды факторов, характеризующих сам объект, управляющие воздействия и окружающую среду (массив-локатор), т.е.: 


$$
\vec{L}_{i}=\left\{\begin{array}{l}
1, \text { если } i-\check{u} \text { фактор действует; } \\
n, \text { где }: n>0, \text { если } i-\check{u} \text { фактор действует с истинностью } n ; \\
0, \text { если } i-\check{u} \text { фактор не действует. }
\end{array}\right.
$$

В текущей версии системы «Эйдос-X++» значения координат вектора состояния распознаваемого объекта принимались равными либо 0, если признака нет, или n, если он присутствует у объекта с интенсивностью n, т.е. представлен n раз (например, буква «о» в слове «молоко» представлена 3 раза, а буква «м» - один раз).

\subsection{2. Интегральный критерий - «Резонанс знаний»}

2-й интегральный критерий «Семантический резонанс знаний» представляет собой нормированное суммарное количество знаний, содержащееся в системе факторов различной природы, характеризующих сам объект управления, управляющие факторы и окружающую среду, о переходе объекта в будущие целевые или нежелательные состояния.

Интегральный критерий представляет собой аддитивную функцию от частных критериев знаний и имеет вид:

$$
I_{j}=\frac{1}{\sigma_{j} \sigma_{l} M} \sum_{i=1}^{M}\left(I_{i j}-\bar{I}_{j}\right)\left(L_{i}-\bar{L}\right)
$$

где:

M - количество градаций описательных шкал (признаков);

$\overline{\mathrm{I}}_{\mathrm{j}} \quad$ - средняя информативность по вектору класса;

$\overline{\mathrm{L}}$-среднее по вектору объекта;

$\sigma_{\mathrm{j}} \quad$ - среднеквадратичное отклонение частных критериев знаний вектора класса;

$\sigma_{1}$ - среднеквадратичное отклонение по вектору распознаваемого объекта.

Приведенное выражение для интегрального критерия «Семантический резонанс знаний» получается непосредственно из выражения для критерия «Сумма знаний» после замены координат перемножаемых векторов их стандартизированными значениями:

$$
I_{i j} \rightarrow \frac{I_{i j}-\bar{I}_{j}}{\sigma_{j}}, \quad L_{i} \rightarrow \frac{L_{i}-\bar{L}}{\sigma_{l}} .
$$

Свое наименование интегральный критерий сходства «Семантический резонанс знаний» получил потому, что по своей математической форме является корреляцией двух векторов: состояния ј-Го класса и состояния распознаваемого объекта. 


\subsection{3. Идентификация объекта с классами}

Экранная форма, в которой для каждого объекта обучающей выборки приводятся все классы в порядке убывания релевантности, приведена на рисунке 11:

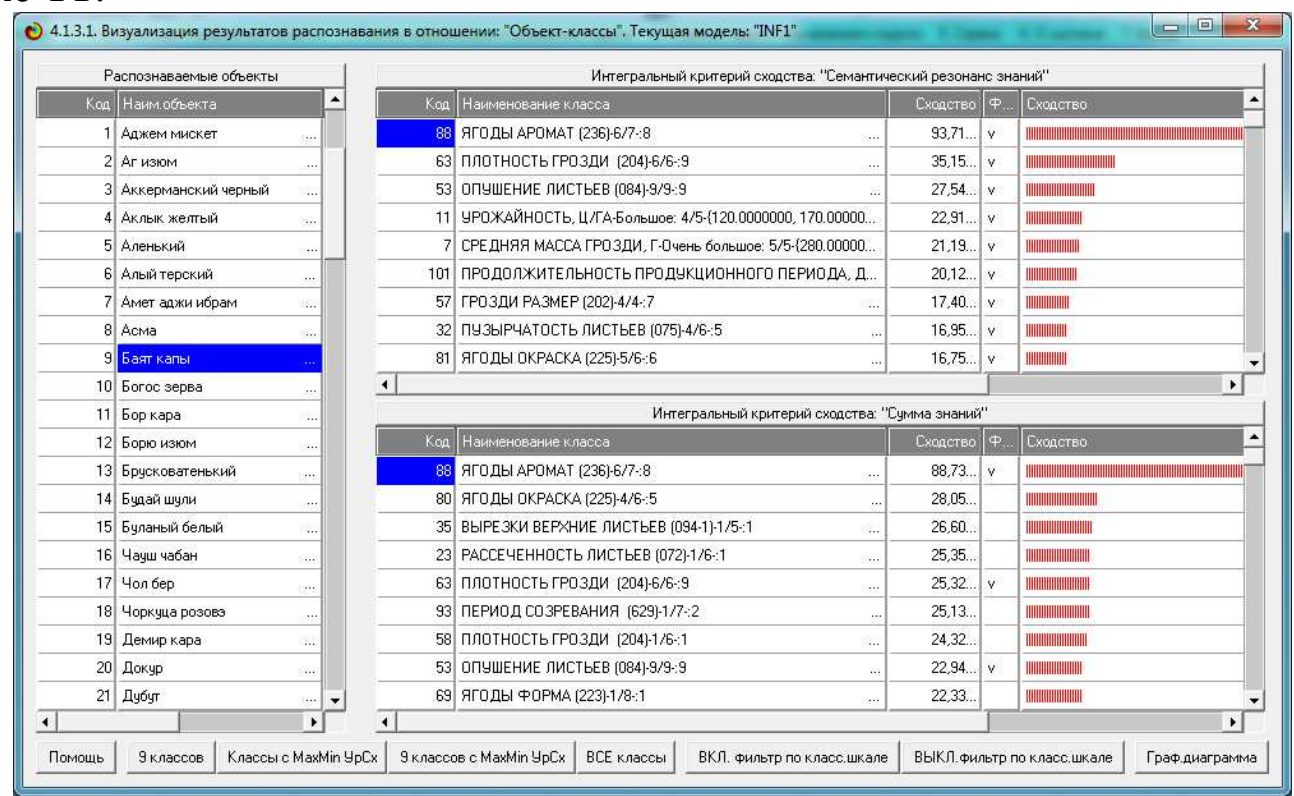

Рисунок 11. Результаты решения задачи идентификации фенотипических признаков и свойств сорта винограда по структуре его генома

\subsection{4. Степень сходства объектов с классом}

Экранная форма, в которой для каждого объекта обучающей выборки приводятся все классы в порядке убывания релевантности, приведена на рисунке 12:

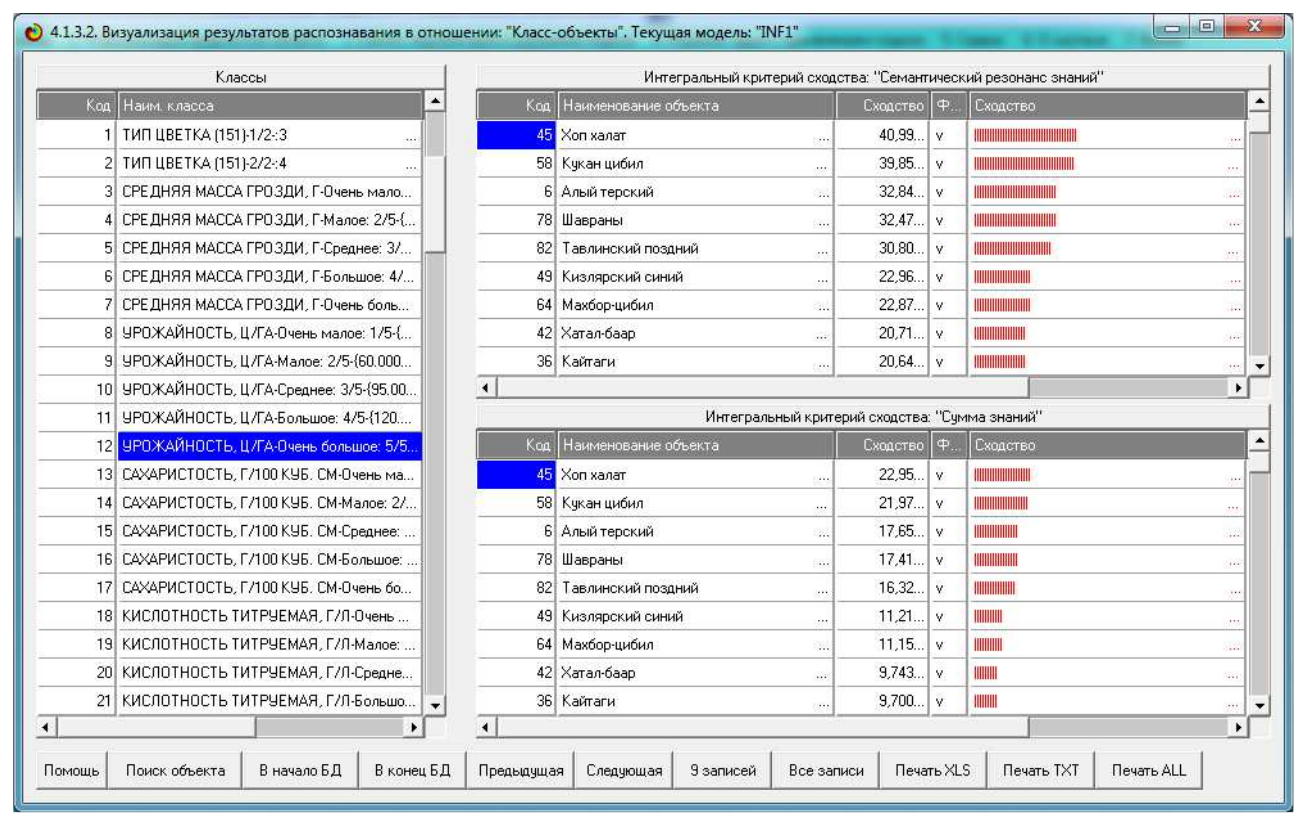

Рисунок 12. Результаты решения задачи идентификации сортов винограда с заданными фенотипическими признаками и свойствами по структуре их генома 
4.5. Автоматизированный SWOT-анализ системы детерминации фенотипических признаков и свойств структурой генома

На экранных формах режима 4.4.8 системы «Эйдос», приведенных на рисунке 13, пользователь может выбрать любое фенотипическое свойство или признак и модель, в которой отображать систему детерминации этого фенотипического свойства/признака структурой генома и степенью выраженности различных генов в двух спиралях ДНК [18]:

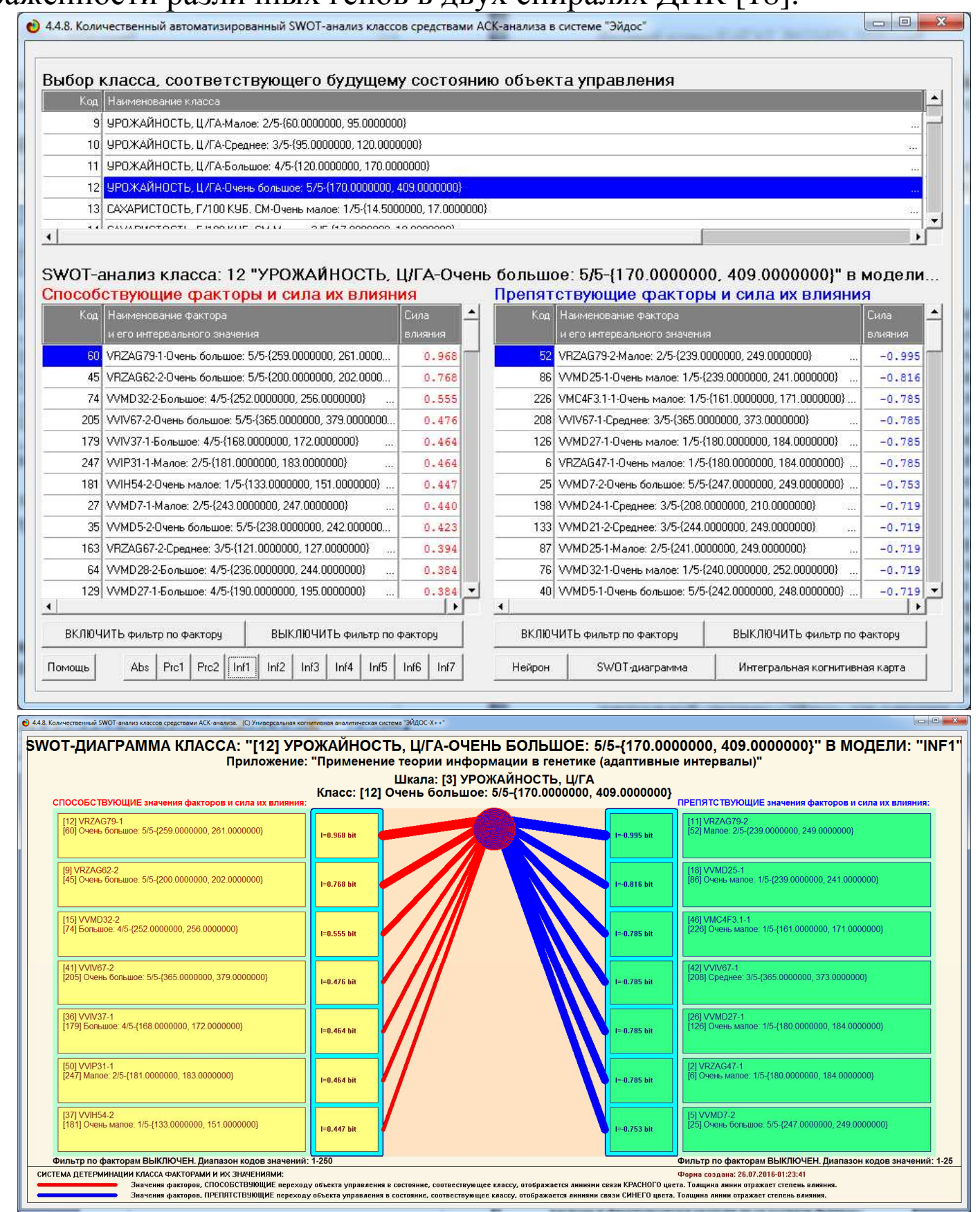

Рисунок 13. Экранные формы автоматизированного SWOT-анализа, показывающие, какие гены способствуют, а какие препятствуют проявлению заданного фенотипического признака/свойства в модели INF1 
В верхней экранной форме, приведенной на рисунке 13, пользователь может выбрать любой ген и включить фильтр по нему. Тогда на экранных формах будет отражено влияние степени выраженности именно этого гена на заданное фенотипическое свойство (рисунок 14):
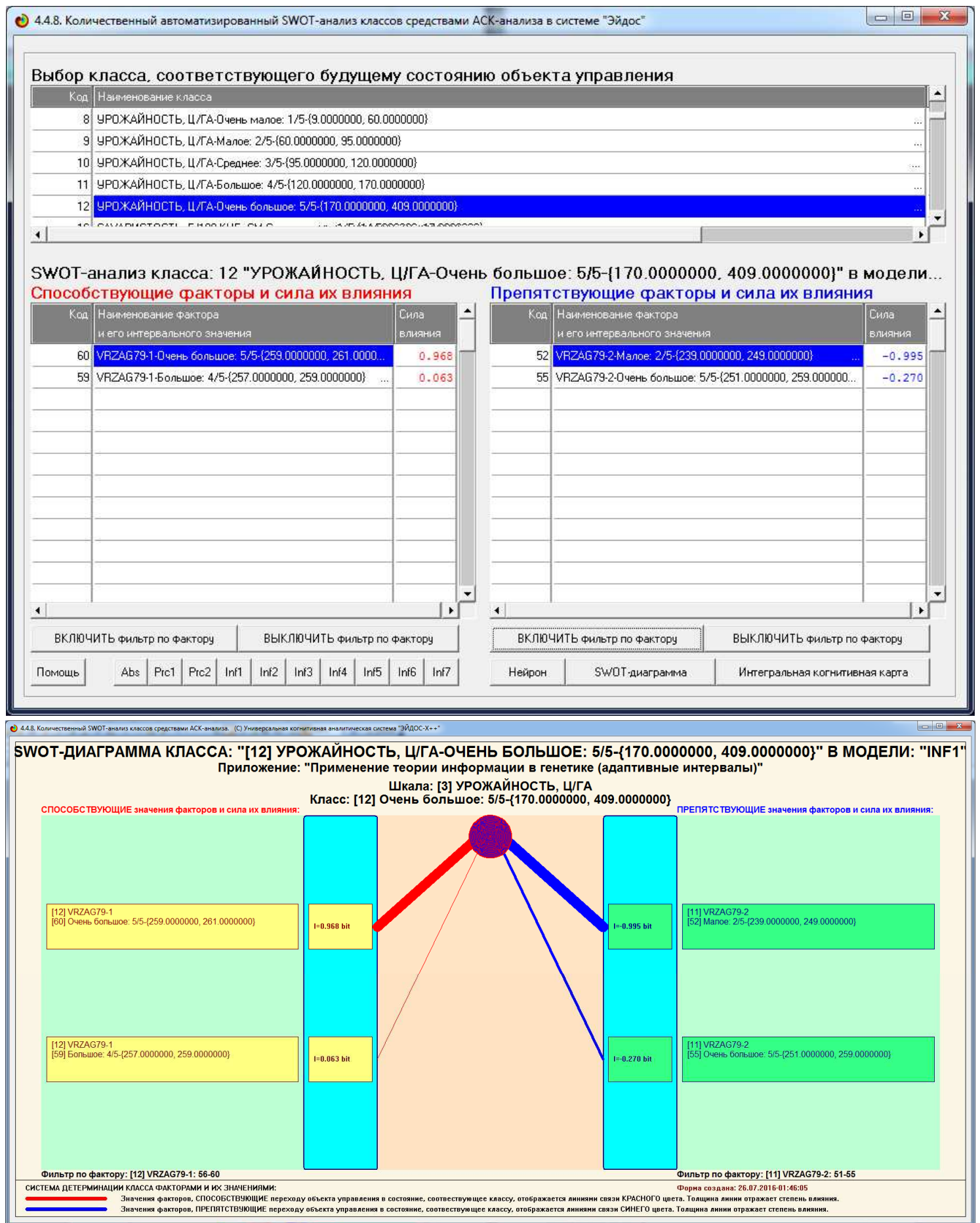

Рисунок 14. Экранные формы автоматизированного SWOT-анализа, показывающие, что высокая степень выраженности гена VRZAG79-1 способствует, а низкая VRZAG79-2 препятствует проявлению фенотипического свойства: «Очень большая урожайность» в модели INF1 
4.6. Автоматизированный SWOT-анализ силы и направления влияния конкретного гена на фенотипические свойства/признаки

На экранных формах режима 4.4.9 системы «Эйдос», приведенных на рисунке 15, пользователь может выбрать любой ген и степень его выраженности в 1-й или 2-й аллели и модель, в которой отображать - какое влияние он оказывает на фенотипические свойства/признаки:

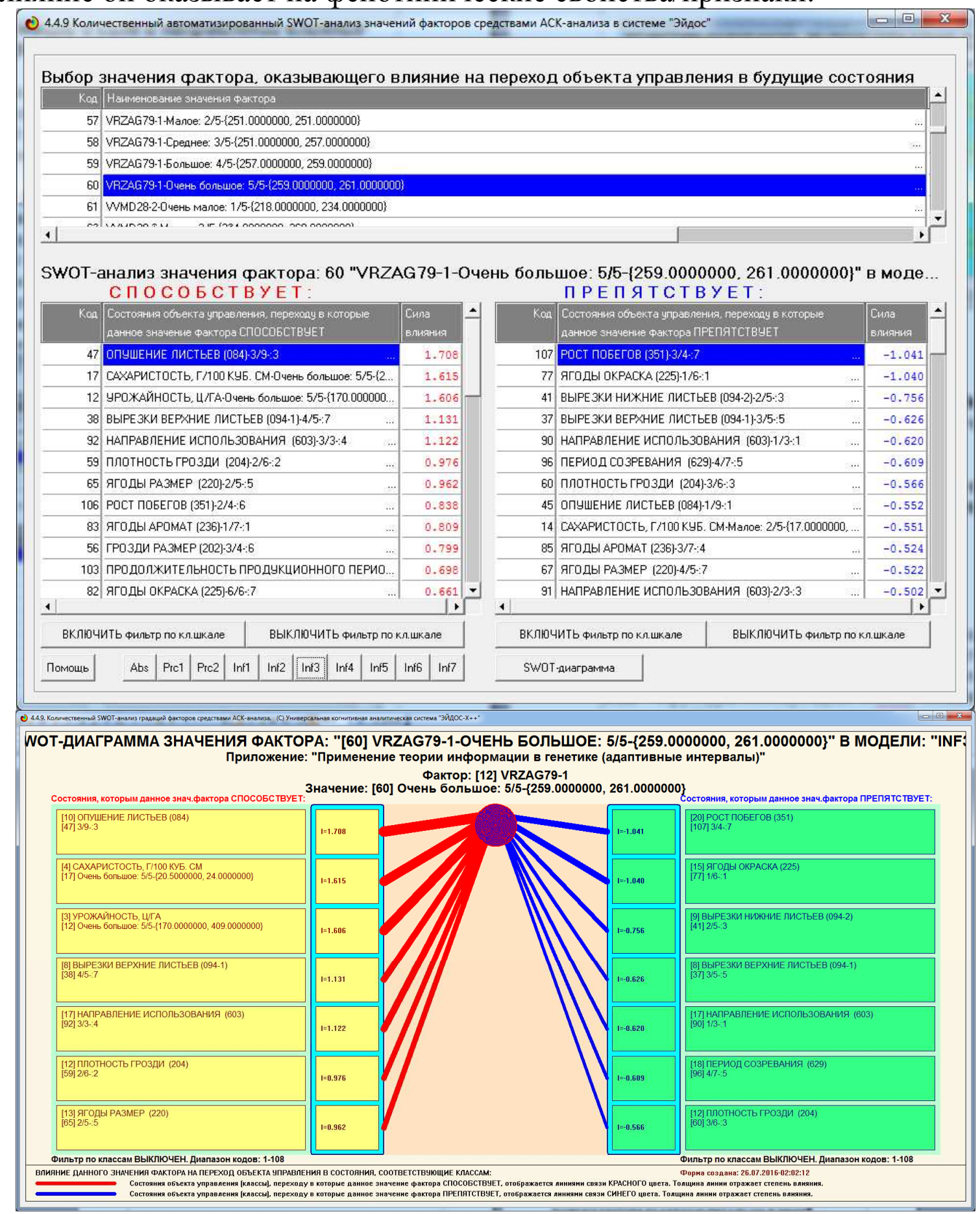

Рисунок 15. Экранные формы автоматизированного SWOT-анализа, показывающие, какое влияние заданный ген оказывает на степень выраженности различных фенотипических свойств/признаков в модели INF3 
В верхней экранной форме, приведенной на рисунке 16, пользователь может выбрать любое фенотипическое свойство и включить фильтр по нему. Тогда на экранных формах будет отражено влияние заданной степени выраженности заданного гена на это фенотипическое свойство (рисунок 17):
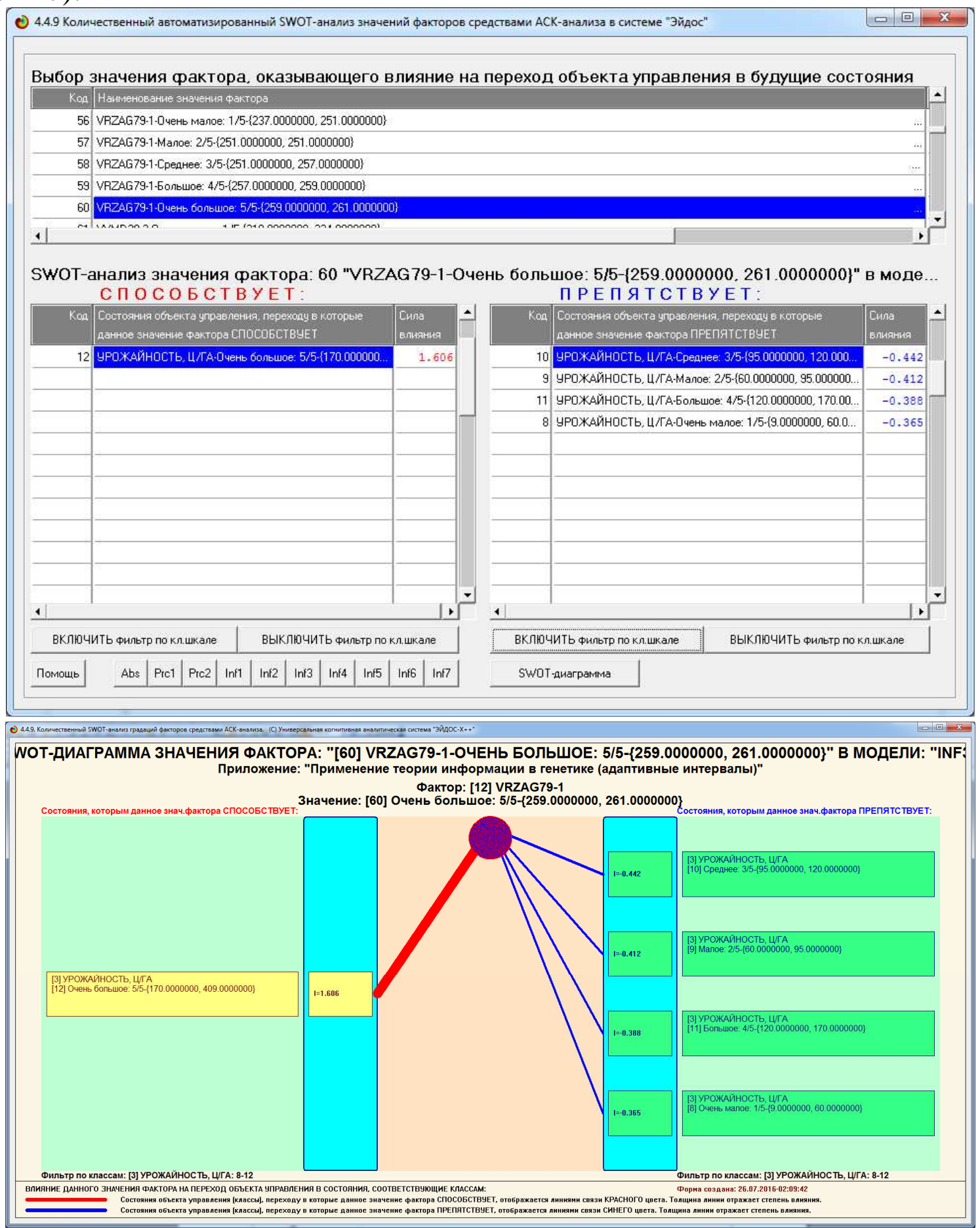

Рисунок 16. Экранные формы автоматизированного SWOT-анализа, показывающие, что высокая степень выраженности гена VRZAG79-1 способствует очень высокой урожайности и препятствует всем остальным степеням выраженности урожайности в модели INF3 
Таким образом, используя автоматизированный когнитивный SWOTанализ генов и фенотипических свойств/признаков, мы можем получить информацию о том, какими генами детерминируется заданное фенотипическое свойство/признак и наоборот, какие фенотипические признаки/свойства обуславливаются заданным геном. Обладание этими знаниями вселяет надежду на возможность получения ответа на вопрос о том, каким должен быть геном, чтобы сорт обладал заданными желательными фенотипическими свойствами.

Однако здесь есть по меньшей мере одна проблема, которая состоит в том, что некоторые фенотипические свойства/признаки детерминируются наличием или сильной выраженностью определенных генов, а другие либо их полным отсутствием, либо слабой выраженностью. Ясно, что одновременно ген не может и присутствовать, и отсутствовать, быть и сильно, и слабо выраженным.

Из этого следует, что некоторые фенотипические свойства/признаки невозможно одновременно получить в одном сорте, а другие вполне возможно. Например, ягода не может быть и сладкой, и кислой, и темной, и светлой. Может быть в этом и состоит оправдание существования многих сортов. Чтобы узнать, конкретно какие свойства совместимы в одном сорте, а какие нет, необходимо провести сравнение различных фенотипических свойств по их системе детерминации генами.

\section{7. Количественное определение сходства-различия} различных фенотипических свойств по их системе детерминации генами. Совместимые и несовместимые фенотипические свойства

Эта задача решается в режиме 4.2.2 системы «Эйдос», в котором сначала рассчитываются матрицы сходства классов (рисунки 17 и 18), а затем они просто визуализируются в форме когнитивных диаграмм или, кроме того, на их основе проводится когнитивный кластерный анализ $[19]^{6}$. Результаты кластерного анализа классов приведены на табличной экранной форме режима 4.2.2.2 (рисунок 19) и в графической форме когнитивной диаграммы (рисунки 20 и 21).

\footnotetext{
${ }^{6}$ Он был реализован в DOS-версии системы «Эйдос», а в новой версии его еще нет.
} 


\subsubsection{1. Расчет матриц сходства, кластеров и конструктов классов}

Задайте модели, для которых проводить кластерно-конструктивный анализ:

Статистические базы:

Mogснение по режимч.......

『 1. ABS - частный критерий: количество встреч сочетаний: "класс-признак" у объектов обуч.выборки

『 2. PRC1 - частный критерий: усл. вероятность і-го признака среди признаков объектов j-го класса

ॠ 3. PRC2 - частный критерий: условная вероятность і-го признака у объектов і-го класса

Базы знаний:

『 4. INF1 - частный критерий: количество знаний по А Харкевичу; вероятности из PRC1

『 5. INF2 - частный критерий: количество знаний по А.Харкевичу; вероятности из PRC2

『 6. INF3 - частный критерий: Хи-квадрат, разности между фактическими и ожидаемыми абс.частотами

『 7. INF4 - частный критерий: ROI (Return On Investment); вероятности из PRC1

『 8. INF5 - частный критерий: ROI (Retum On Investment); вероятности из PRC2

『 9. INF6 - частный критерий: разн.усл.и безусл.вероятностей; вероятности из PRC1

『 10.INF7 - частный Критерий: разн.усл.и безусл.вероятностей; вероятности из PRC2

Задайте диапазон кодов классов (подматрицу) для анализа:

1

$\underline{\underline{Q}} \mathrm{k}$

Cancel

Рисунок 17. Форма задания параметров формирования матрицы сходства классов

Помощь по режиму: "4.2.2. Кластерный и конструктивный анализ классов"

кластерно-конструктивный анализ - это математический метод анализа данных,

обеспечивающий:

- выявление классов, наиболее сходных по системе их детерминации и объединение их в

кластеры;

- выявление кластеров классов, наиболее сильно отличаюциеся по системе их детерминации и построение из них полюсов конструктов классов, при этом остальные кластеры включаются в

конструкты в качестве промежуточных между полюсами;

- выявление факторов, наиболее сходных по детерминируемым ими классам и объединение их в

кластеры;

- выявление кластеров факторов, наиболее сильно отличающиеся по детерминируемым ими

классам и построение из них полюсов конструктов факторов, при этом остальные кластеры включаются в конструкты в качестве промежуточных между полюсами.

состояния объекта управления, соответствующие классам, включенным в один кластер, могут быть достигнуты одновременно, т.е. являются совместимыми (коалиционными) по детерминирующим их факторам. Состояния объекта управления, соответствующие классам, образующим полюса конструкта, не могут быть достигнуты одновременно, т.е. являются противоположными по детерминирующим их факторам (антагонистическими).

КОНСТРУКТ КЛАССОВ ПРЕДСТАВЛЯЕТ СОБОЙ СИСТЕМУ ПРОТИВОПОЛОЖНЫХ, Т.Е. НАИБОЛЕЕ НЕПОХОЖИХ ДРУГ НА ДРУГА КЛАССОВ (КОТОРЫЕ НАЗЫВАЮТСЯ ПОЛЮСАМИ КОНСТРУКТА) И СПЕКТР ПРОМЕХУТОЧНЫХ КЛАССОВ, РАСПРЕДЕЛЕННЫХ МЕЖДУ ПОЛЮСАМИ В СООТВЕТСТВИИ СО СВОИМ СХОДСТВОМ-РАЗЛИЧИЕМ С НИМИ.

Факторы, включенные в один кластер, оказывают сходное влияние на поведение объекта управления и могут, при необходимости, быть использованы для замены друг друга. Факторы, образующие полюса конструкта, оказывают противоположное влияние на поведение объекта управления.

Кластерно-конструктивный анализ классов позволяет сравнить их по сходству системы детерминации и отобразить эту информацию в наглядной графической форме 2 d семантической сети классов.

кластерно-конструктивный анализ факторов позволяет сравнить факторы по сходству их влияния на переход объекта в будущие состояния и отобразить эту информацию в наглядной графической форме семантической сети факторов.

Рисунок 18. Неlp режима кластерного анализа классов системы «Эйдос» 


\begin{tabular}{|c|c|c|c|c|c|c|c|c|c|c|c|c|c|c|c|c|c|c|}
\hline \multicolumn{14}{|c|}{ () 4.2.2.2. Результаты кластерно-конструктивного анализа классов } & \multicolumn{3}{|c|}{ 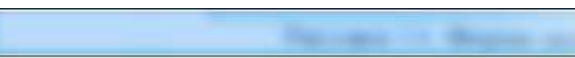 } & \multicolumn{2}{|c|}{\begin{tabular}{|l|l|l|}
0 & 回 & $x$ \\
\end{tabular}} \\
\hline \multicolumn{19}{|c|}{ Конструкт класса: 12 "УРОЖАЙНОСТЬ, Ц/ГА-Очень большое: 5/5-\{170.0000000, 409.0000000\}" в модели: 4 "INF1" } \\
\hline Kog & \multicolumn{7}{|c|}{ Haименование класса } & & & & $\mathrm{N}=\sqrt{\mathrm{r}}$ & \multicolumn{2}{|c|}{ Kog knacca } & \multicolumn{3}{|c|}{ Наименование класса } & Exодство & $\Delta$ \\
\hline 1 & \multicolumn{8}{|c|}{ ТИП ЦВЕТКА (151)-1/2:3 } & & & 1 & & 12 & \multicolumn{3}{|c|}{ УРОЖАЙНОСТЬ, Ц/ГА-Очень большое: $5 / 5-\{170.0000000,409.00 \ldots$} & 100.000 & \\
\hline 2 & \multicolumn{8}{|c|}{ ТИП ЦВЕТКА $(151)-2 / 2 \div 4$} & & & 2 & & 98 & \multicolumn{3}{|c|}{ ПЕРИОД СОЗРЕВАНИЯ (629)-6/7-7 } & 40.236 & \\
\hline 3 & \multicolumn{8}{|c|}{ СРЕДНЯЯ МАССА ГРОЗДИ, Г-Очень малое: $1 / \ldots$} & & & 3 & & 81 & \multicolumn{3}{|c|}{ ЯГОДЫ ОКРАСКА (225)-5/6:6 } & 38.459 & \\
\hline 4 & \multicolumn{8}{|c|}{ СРЕДНЯЯ МАССА ГРОЗДИ, Г-Малое: $2 / 5-\{112 \ldots$} & & & 4 & & 66 & \multicolumn{3}{|c|}{ ЯГОДЫ РАЗМЕР (220)-3/5:6 } & 37.895 & \\
\hline 5 & \multicolumn{8}{|c|}{ СРЕДНЯЯ МАССА ГРОЗДИ, Г-Среднее: $3 / 5-\{17 \ldots$} & & & 5 & & 2 & \multicolumn{3}{|c|}{ ТИП ЦВЕТКА (151)-2/2:4 } & 36.689 & \\
\hline 6 & \multicolumn{8}{|c|}{ СРЕДНЯЯ МАССА ГРОЗДИ, Г-Большое: $4 / 5\{22 .}$. & & & 6 & & 7 & \multicolumn{3}{|c|}{ СРЕДНЯЯ МАССА ГРОЗДИ, Г-Очень большое: $5 / 5-\{280.0000000, \ldots$} & 36.289 & \\
\hline 7 & \multicolumn{8}{|c|}{ СРЕДНЯЯ МАССА ГРОЗДДИ, Г-Очень большое: .... } & & & 7 & & 44 & \multicolumn{3}{|c|}{ ВЫРЕЗКИ НИЖНИЕ ЛИСТЬЕВ (094-2)-5/5:9 } & 34.985 & \\
\hline 8 & \multicolumn{8}{|c|}{ УРОЖАЙНОСТЬ, Ц/ГА-Очень малое: $1 / 5-\{9.000 \ldots$} & & & 8 & & 43 & \multicolumn{3}{|c|}{ ВЫРЕЗКИ НИЖНИЕ ЛИСТЬЕВ (094-2)-4/5:7 } & 29.462 & \\
\hline 9 & \multicolumn{8}{|c|}{9 УРОЖАЙНОСТЬ, Ц/ГА-Малое: $2 / 5-\{60.0000000 \ldots$} & & & 9 & & 20 & \multicolumn{3}{|c|}{ КИСЛОТНОСТЬ ТИТРУЕМАЯ, Г/Л-Среднее: $3 / 5-\{6.4000000,6.90 \ldots$} & 28.466 & \\
\hline 10 & \multicolumn{8}{|c|}{ УРОЖАЙНОСТЬ, Ц/ГА.Среднее: $3 / 5-\{95.00000 \ldots$} & & & 10 & & 91 & НАПРАВЛЕНИЕ ИСГ & ПОЛЬЗОВАНИЯ (603)-2/3:3 & & 27.701 & \\
\hline 11 & YPO & ОАЙН & OCTь, & Ц/ГА & ольшо & e: $4 / 5-\{$ & 120.0000 . & & & & 11 & & 58 & ПлОТНОСТЬ ГРОЗГ & ди (204)-1/6:1 & $\ldots$ & 27.261 & \\
\hline 12 & YPO & ЖАЙН & OCTb, & L/ГA-0 & чень 6 & ольшое & $5 / 5\{17$ & & & & 12 & & 59 & ПЛОТНОСТЬ ГРОЗГ & ди $(204) \cdot 2 / 6: 2$ & $\ldots$ & 27.009 & \\
\hline 13 & $C A X$ & $\triangle \mathrm{APUCT}$ & OCTь, & $\Gamma / 100 \mathrm{~K}$ & KYE. CR & М-Очень & b малое: & & & & 98 & & 26 & PACCEЧЕНHОСТЬ Л & ПИСТЬЕВ (072)-4/6:6 & $\ldots$ & -23.337 & \\
\hline 14 & $\operatorname{cAx}$ & $\triangle \mathrm{APИCT}$ & ость, & $\Gamma / 100 \mathrm{~K}$ & KYE. CK & М-Мало & $2 / 5 \cdot\{1$ & & & & 99 & & 87 & ЯГОДЫ АРОМАТ (2: & $36)-5 / 7 \cdot 7$ & $\ldots$ & -23.461 & \\
\hline 15 & $\cos$ & СAPИCT & OCTь, & $\Gamma / 100 \mathrm{~K}$ & KYE. CK & M-Cpen & Hee: $3 / 5-\{$ & & & & 100 & & 108 & POСТ ПОБЕГОВ & $11-4 / 4: 9$ & & -24.865 & \\
\hline 16 & $\operatorname{CAX}$ & $\triangle \mathrm{APUCT}$ & OCTb, & $\Gamma / 100 \mathrm{k}$ & KYE. CR & М-Боль- & woe: $4 / 5$. & & & & 101 & & 80 & ЯГОДЫ ОКРАСКА (2 & $225]-4 / 6 \div 5$ & $\ldots$ & -25.073 & \\
\hline 17 & $\operatorname{cox}$ & $\triangle \mathrm{APUCT}$ & OCTь, & $\Gamma / 100 \mathrm{~K}$ & KYE. CR & М-Очень & b 6ольшо. & & & & 102 & & 1 & ТИП ЦВЕТКА (151)-1 & $1 / 2: 3$ & & -25.950 & \\
\hline 18 & KUC & Слотно & Ость Т & ИTPYE & MAЯ, Г & $7 / 1-04$ & ень мало. & & & & 103 & & 16 & САХАРИСТОСТЬ,Г/ & 1100 КУБ. СМ-Большое: 4/5-\{1 & $18.7000000,20.5 \ldots$ & -26.254 & \\
\hline 19 & KUC & Слотно & DСТЬ T & UTPYE & MA, Г & $7 / \mathrm{Ma}$ & лое: $2 / 5-\{$ & & & & 104 & & 10 & УРОЖАЙНОСТЬ, Ц/ & ГА-Среднее: $3 / 5 \cdot\{95.0000000$ & $0,120.0000000\} \ldots$ & -27.121 & \\
\hline 20 & KUC & слотно & ОСТь Т & ИTPYE & MA, I & - $/$ / Сpe & еднее: $3 /$. & & & & 105 & & 96 & ПЕРИОД СОЗРЕВАН & НИЯ $(629)-4 / 7 \div 5$ & $\ldots$ & -32.969 & \\
\hline 21 & KИС & слотно & OCTь T & ИTPYE & MAA, I & $7 / \pi-6$ or & ทьшое: $4 /$. & & & & 106 & & 92 & НАПРАВЛЛЕНИЕ ИСГ & ПОЛЬЗОВАНИЯ (603)-3/3:4 & $\ldots$ & -33.661 & \\
\hline 22 & $\mathrm{KUC}$ & СЛОTHO & ОСТь Т & UTPYE & MA, I & $7 / \pi-04$ & ннь боль. & & & & 107 & & 9 & УРОЖАЙНОСТЬ, Ц/ & /ГА-Малое: $2 / 5-\{60.0000000,9$ & $95.0000000\}$ & $. \quad-34.969$ & \\
\hline 1 & $\mathrm{PACC}$ & CEYEH & HOCTL & ЛИСТ & bEB 10 & $721-1 / 6$ & & $\ldots$ & 1 & & 108 & & 37 & ВЫРЕ ЗКИ ВЕРХНИЕ & Е ЛИСТЬЕВ $1094-11-3 / 5: 5$ & & -34.974 & \\
\hline Помощь & Abs & Prc1 & Prc2 & $\ln f 1$ & $\ln f 2$ & $\ln 13$ & $\ln 14 \quad 1$ & $\ln 55$ & $\ln 66$ & $\ln f 7$ & & оафик & ВКЛ.Ф & фильтр по кл.шкале & ВЫКЛ.Фильтр по кл.шкале & Вписать в окно & Показать ВC & \\
\hline
\end{tabular}

Рисунок 19. Табличная форма с результатом кластерного анализа классов

Имеется возможность сразу получить графическую диаграмму, соответствующую приведенной таблице. Однако в этом случае эта диаграмма будет нечитабельна из-за большого количества графических элементов. Поэтому перед отображением графической диаграммы кликнем на кнопке: «Вписать в окно» на появившейся экранной форме, приведенной на рисунке 19, зададим 12 отображаемых классов, нажмем OK, а уже затем кликнем по кнопке: «График» (рисунок 20):

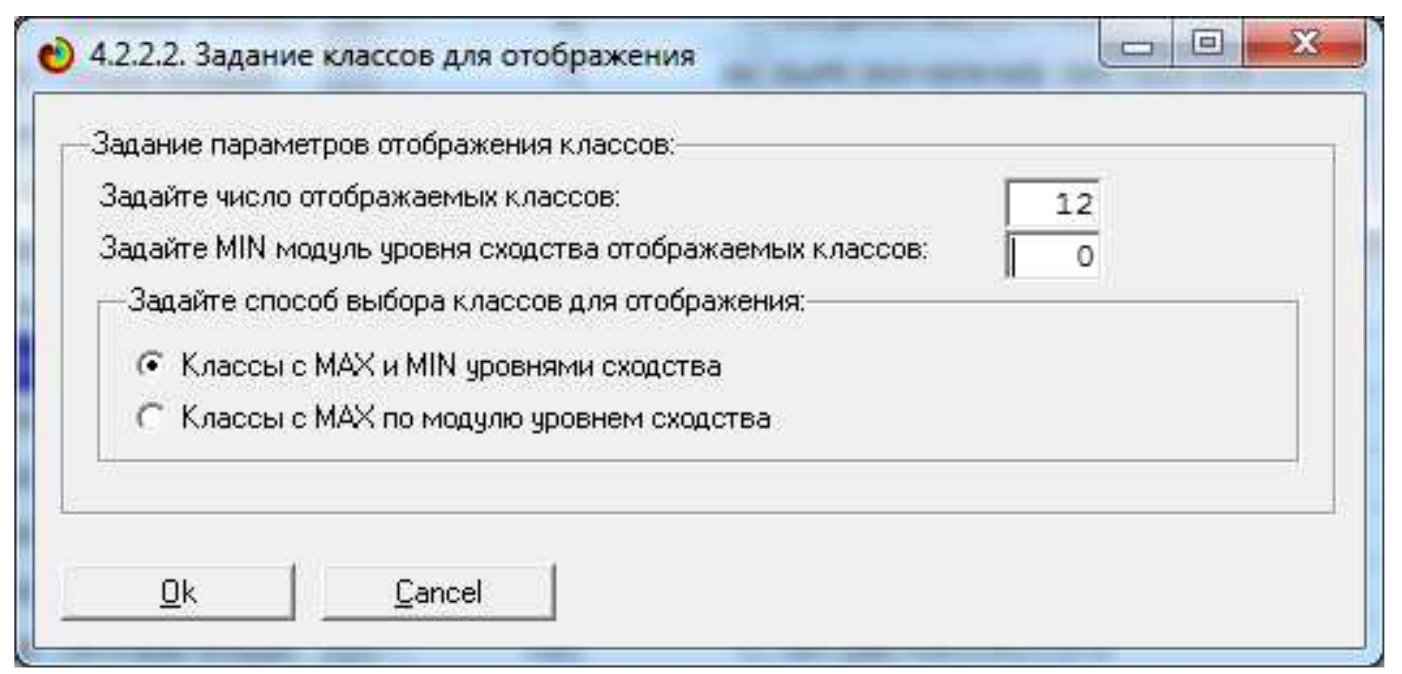

Рисунок 20. Задание параметров графической диаграммы

с результатами кластерно-конструктивного анализа 
А затем выведем саму диаграмму:

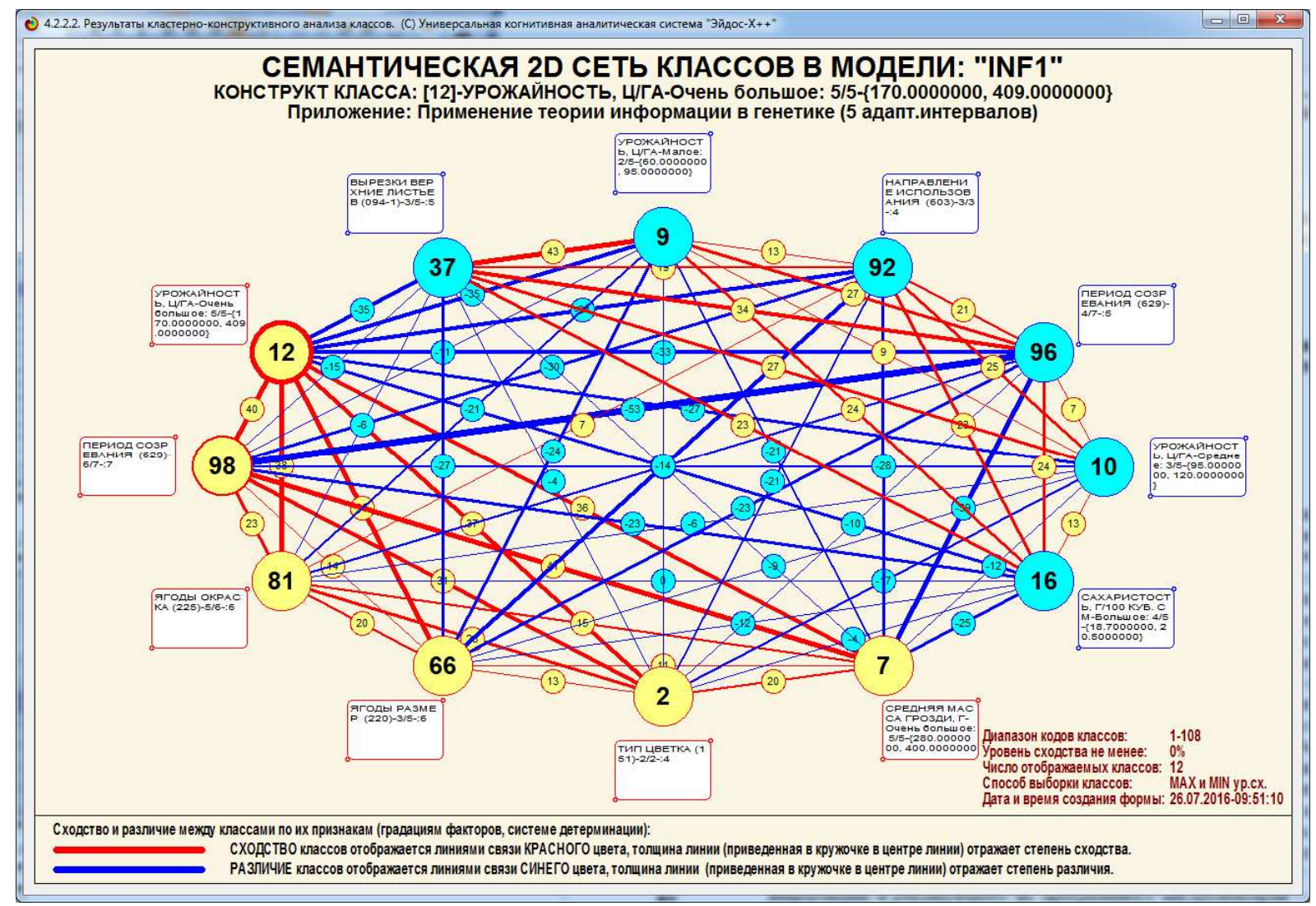

Рисунок 21. Когнитивная диаграмма с результатами кластерно-конструктивного анализа

На этой диаграмме изображен конструкт с двумя кластерами на полюсах. На одном полюсе кластер с центром в классе - код: 12 «Урожайность очень большая» (этот центр мы задаем в экранной форме, приведенной на рисунке 19) и классами 98, 81, 66 и 2, а на другом полюсе мы видим кластер с фенотипическими признаками: 37, 9, 92, 93, 10, 16.

Классы, находящиеся в одном кластере, детерминируются сходными системами генов и достижимы одновременно в одном сорте.

Классы, относящиеся к противоположным кластерам, находящимся на полюсах конструкта, не достижимы одновременно в одном сорте.

Например, перед селекционерами корректно ставить задачу получить высокоурожайный сорт винограда с окраской ягод 225 (код: 81) и размером ягод 220 (код: 66), и очень массивной гроздью (код: 7), при этом у этого сорта будет длительный период созревания 629 (код: 98). А вот требовать от селекционеров, чтобы эти ягоды были сладкими (код: 16) некорректно, т.к. это требует совершенно другого генома, чем обуславливающий ранее перечисленные фенотипические свойства. Если же мы хотим получить сладкий сорт, то, по-видимому, придется смириться с его малой или в лучшем случае средней урожайностью. 
Отметим, что обычно подобными знаниями располагают только эксперты в данной предметной области, а в данной работе показано, как они могут быть получены с помощью современных автоматизированных интеллектуальных технологий (АСК-анализа и системы «Эйдос») непосредственно на основе эмпирических данных.

\section{8. Количественное определение сходства-различия различных генов по их влиянию на фенотипических свой- ства. Возможность замены одних генов другими}

Традиционно считается, что определенные гены обуславливают соответствующие фенотипические свойства и эти свойства не могут быть детерминированы другими генами. Но наше исследование показывает, что, по-видимому, это не так. Об этом говорит факт сходства между генами по их влиянию на фенотип, из-за чего они объединяются в кластеры, а противоположные кластеры образуют полюса конструктов. В одном кластере оказываются гены, оказывающие сходное влияние на фенотипические свойства, а на полюсах конструкта - противоположное.

Для получения соответствующих выходных форм сначала сформируем матрицу сходства генов по их влиянию, а потом отобразим ее в табличном и графическом виде (рисунки 22 и 23):

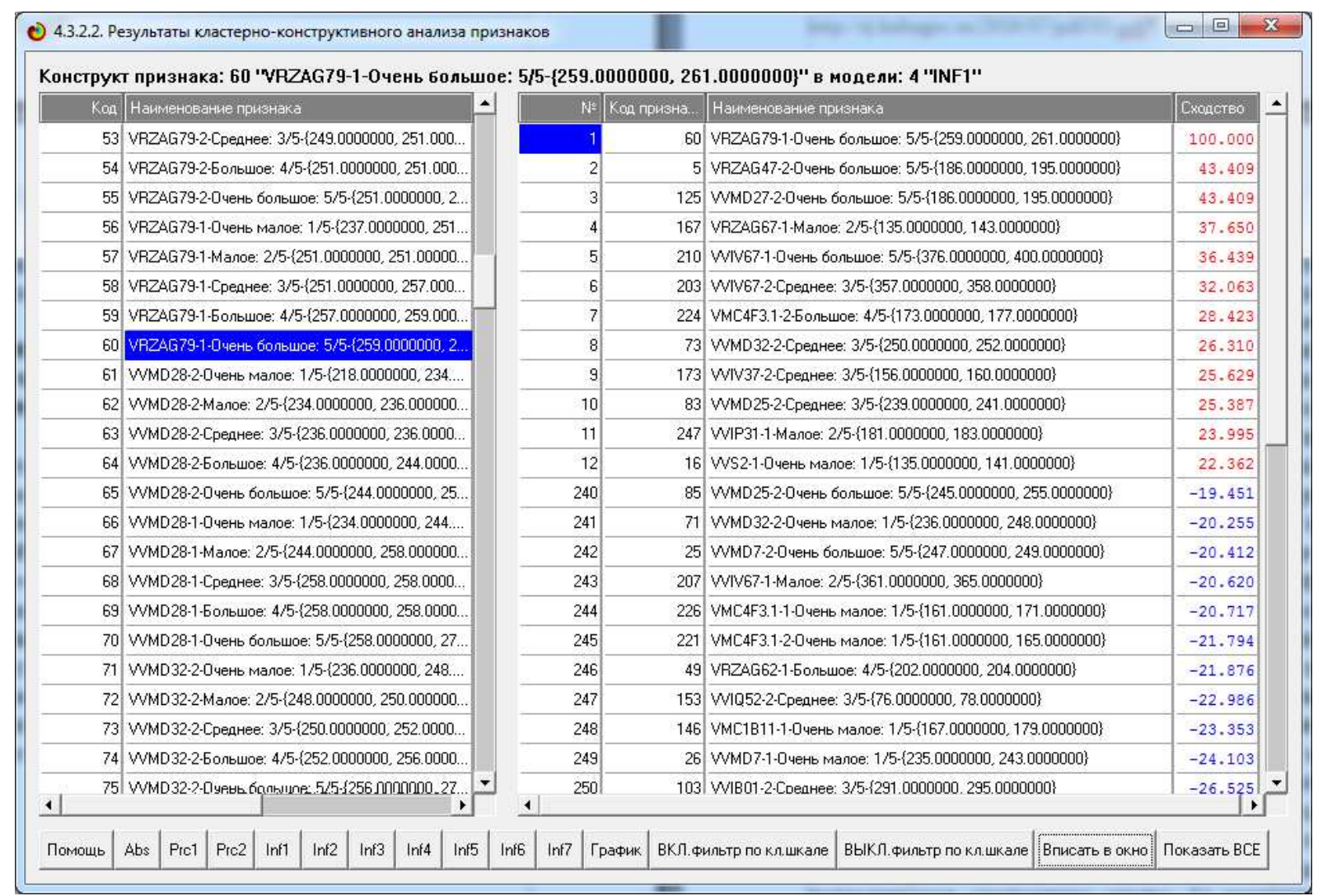

Рисунок 22. Результат кластерно-конструктивного анализа генов по их влиянию на фенотип 


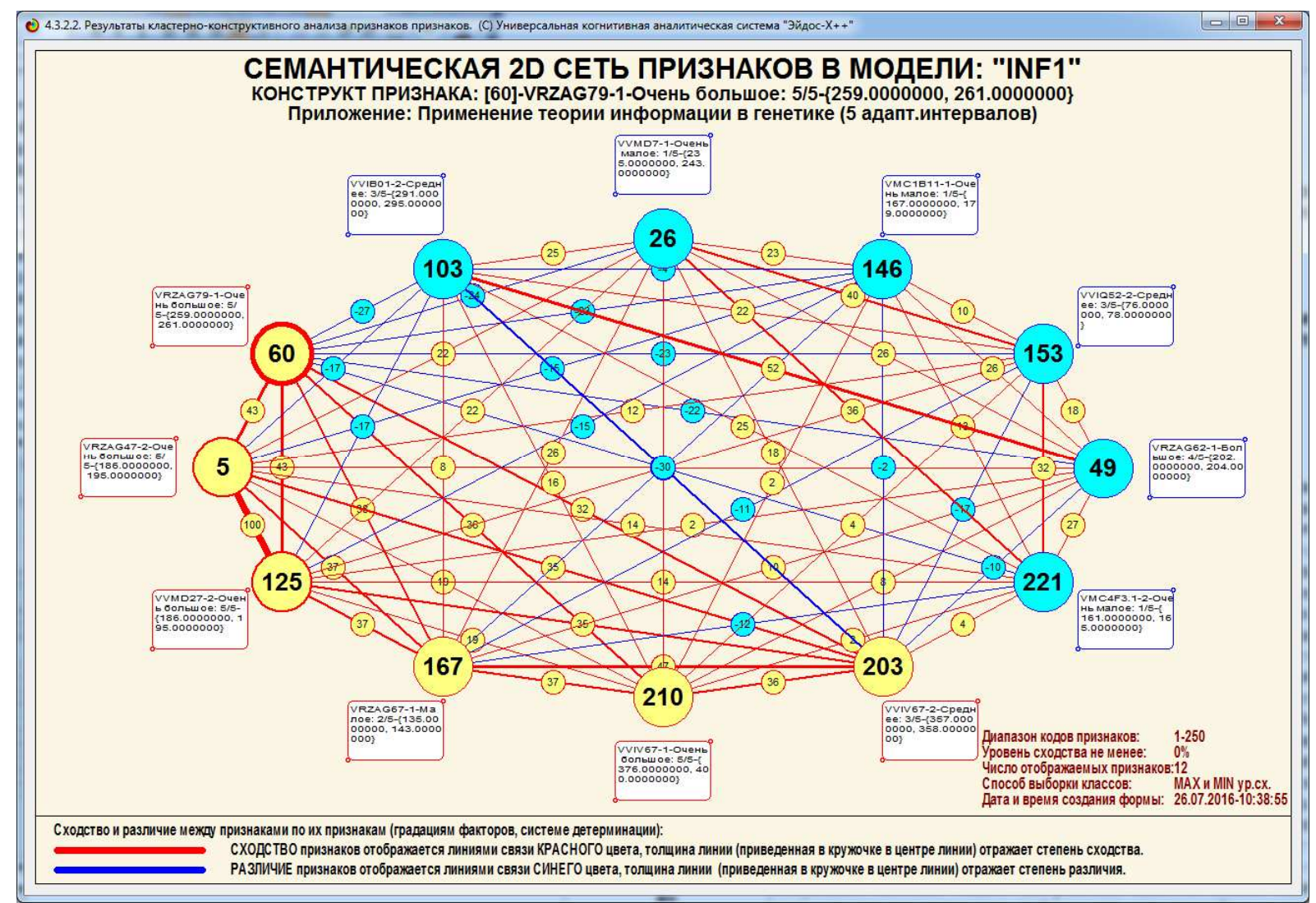

Рисунок 23. Результат кластерно-конструктивного анализа генов по их влиянию на фенотип

Из этих выходных форм видно, какие гены оказывают сходное, а какие - противоположное влияние на фенотип. Если бы между генами и фенотипическими признаками/свойствами было взаимно-однозначное соответствие, то между ними не было бы сходства и различия по их влиянию на фенотип, т.е. их система была бы ортонормированна.

Отметим, что обычно подобными знаниями располагают только эксперты в данной предметной области, а в данной работе показано, как они могут быть получены с помощью современных автоматизированных интеллектуальных технологий (АСК-анализа и системы «Эйдос») непосредственно на основе эмпирических данных.

\section{9. Алгоритм принятия решения о структуре генома с целью создания нового сорта с заданной системой феноти- пических свойств/признаков}

Авторы предлагают следующий алгоритм принятия решения о структуре генома с целью создания нового сорта с заданной системой фенотипических свойств/признаков, по сути совпадающий с логикой изложения в данной работе (предполагающий, что все этапы АСК-анализа до создания и верификации моделей успешно выполнены): 
Шаг-1: 4.7. Количественное определение сходства-различия различных фенотипических свойств по их системе детерминации генами. Выбираем совместимые в одном сорте фенотипические свойства.

Шаг-2: 4.5. Провести автоматизированный SWOT-анализ системы детерминации каждого из выбранных на 1-м шаге фенотипического свойства структурой генома. Выбрать гены, детерминирующие выбранные фенотипические свойства.

Шаг-3: Исключить повторы генов, выбранных на 2-м шаге.

Шаг-4: 4.4. Решить задачу системной идентификации сорта по выбранным на 3-м шаге генам. Этот сорт и берем за основу для селекции.

Для выполнения 4-го шага создаем еще одну модель совершенно аналогично описанному выше, но в качестве классов выбираем наименования сортов, а в качестве признаков - гены. Авторами эта модель создана. На рисунке 24 приводится одна из форм, отражающая результаты кластерно-конструктивного анализа сравнения сортов по их геному в этой модели:

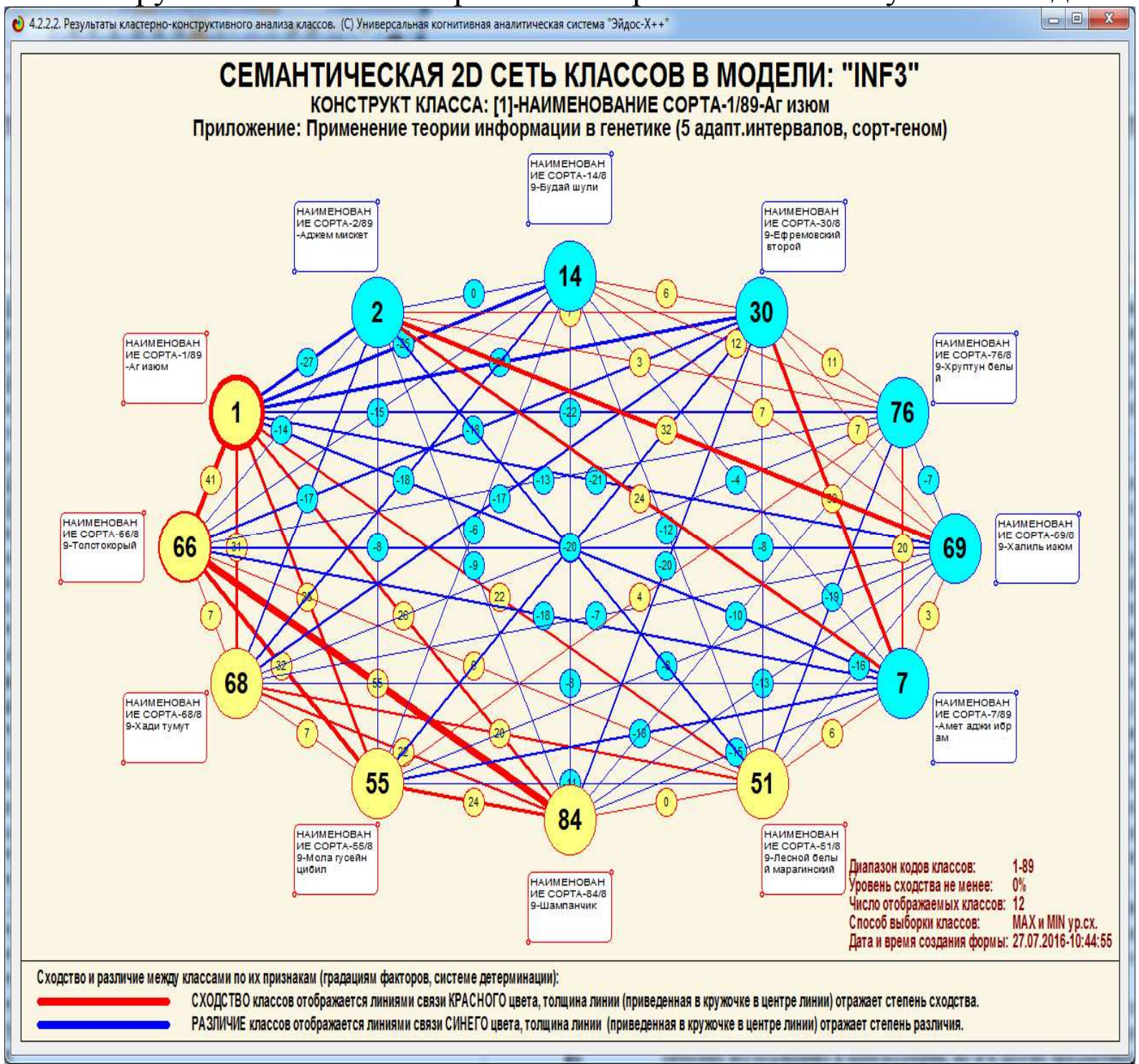

Рисунок 24. Результаты кластерно-конструктивного анализа сравнения сортов по их геному 


\subsection{0. Когнитивные функциональные зависимости между структурой генома и степенью выраженности фенотипиче- ских свойств/признаков}

Когнитивные функции - это предложенное проф. Е.В. Луценко обобщение классического понятия функциональной зависимости на основе теории информации в системной нечеткой интервальной математике [20]. Для их генерации и визуализации в системе «Эйдос» предназначен режим 4.5 (рисунок 25):

\section{5. Визуализация когнитивных функций}

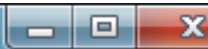

Что такое когнитивная функция:

Визуализация прямых, обратных, позитивных, негативных, полностью и частично редуцированных когнитивных функций Когнитивная функция представляет собой графическое отображение силы и направления влияния различных значений некоторого фактора на переходы объекта управления в будущие состояния, соответствующие классам. Когнитивные функции представляют собой новый перспективный инструмент отражения и наглядной визуализации закономерностей и эмпирических законов. Разработка содержательной научной интерпретации когнитивных функций представляет собой способ познания природы, общества и человека. Когнитивные функции могут бьть: прямые, отражающие зависимость классов от признаков, обобщающие информационные портреты признаков; обратные, отражающие зависимость признаков от классов, обобщающие информационные портреты классов; позитивные, показывающие чему способствуют система детерминации; негативные, отражающие чему препятствуют система детерминации; средневзвешенные, отражающие совокупное влияние всех значений факторов на поведение объекта (причем в качестве весов наблюдений используется количество информации в значении аргумента о значениях функции) различной степенью редукции или степенью детерминации, которая отражает в графической форме (в форме полосы) количество Знаний в аргументе о значении функции и является аналогом и обобщением доверительного интервала. Если отобразить подматрицу матрицы знания, отображая цветом силу и направление влияния каждой градации некоторой описательной шкалы на переход объекта в состояния, соответствующие классам некоторой классификационной шкалы, то получим нередуцированную когнитивную функцию. Когнитивные функции являются наиболее развитым средством изучения причинно-следственных зависимостей в моделируемой предметной области, предоставляемым системой "Эйдос". Необходимо отметить, что на вид функций влияния математической моделью СК-анализа не накладывается никаких ограничений, в частности, они могут бьпь и не дифференцируемые. См.: Луценко Е.В. Метод визуализации когнитивных функций - новый инструмент исследования эмпирических данных большой размерности / Е.В. Луценко, А.П. Трунев, Д.К. Бандык // Политематический сетевой электронный научный журнал Кубанского государственного аграрного университета (Научный журнал КубГАЧ) [Электронный ресурс]. - Краснодар: КубГАЧ, 2011. №03(67). С. 240 - 282. - Шифр Информрегистра: 0421100012\0077. , 2,688 у.п.л. - Режим доступа: http://ei.kubaqro.ru/2011/03/pdt/18.pdf

Задайте нужный режим:

Визуализации когнитивных функции́ Скачать подборку публикаций по когнитивныМ ФункцияМ

Литератур.ссылки на статьи по когнитивным функциям Скачать подборку публикаций по управлению знаниями

Рисунок 25. Начальная экранная форма режима визуализации когнитивных функций

Модуль визуализации когнитивных функций разработан по постановке проф. Е.В. Луценко разработчиком интеллектуальных систем из Белоруссии Д.К. Бандык [21].

На рисунке 26 приведена визуализации всей базы знаний INF1 [8], а на рисунке 28 - примеры некоторых когнитивных функций: 


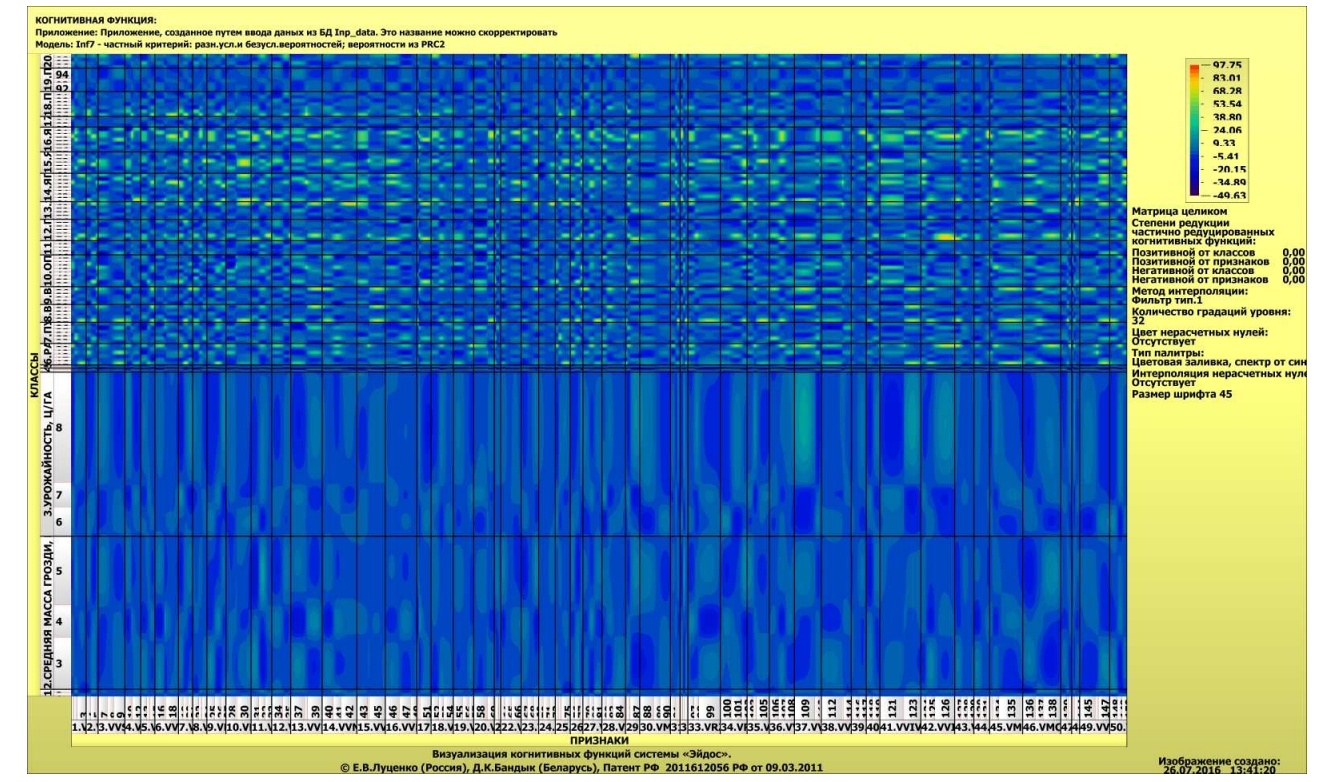

Рисунок 26. Когнитивная функция всех подматриц модели INF1

Всего в каждой из 7 моделей знаний получается подобных 1000 когнитивных функций, т.к. в каждой модели знаний 20 классификационных шкал и 50 описательных шкал, т.е. 1000 подматриц (на рисунке они отделены черными линиями).

Если бы в предметной области не было ярко выраженных закономерностей, то изображение на рисунке напоминало бы изображение на экране телевизора при отсутствии сигнала (случайная рябь). На рисунке приведено изображение базы знаний модели INF1 случайной модели [22], созданной на основе модели, представленной на рисунке 26:

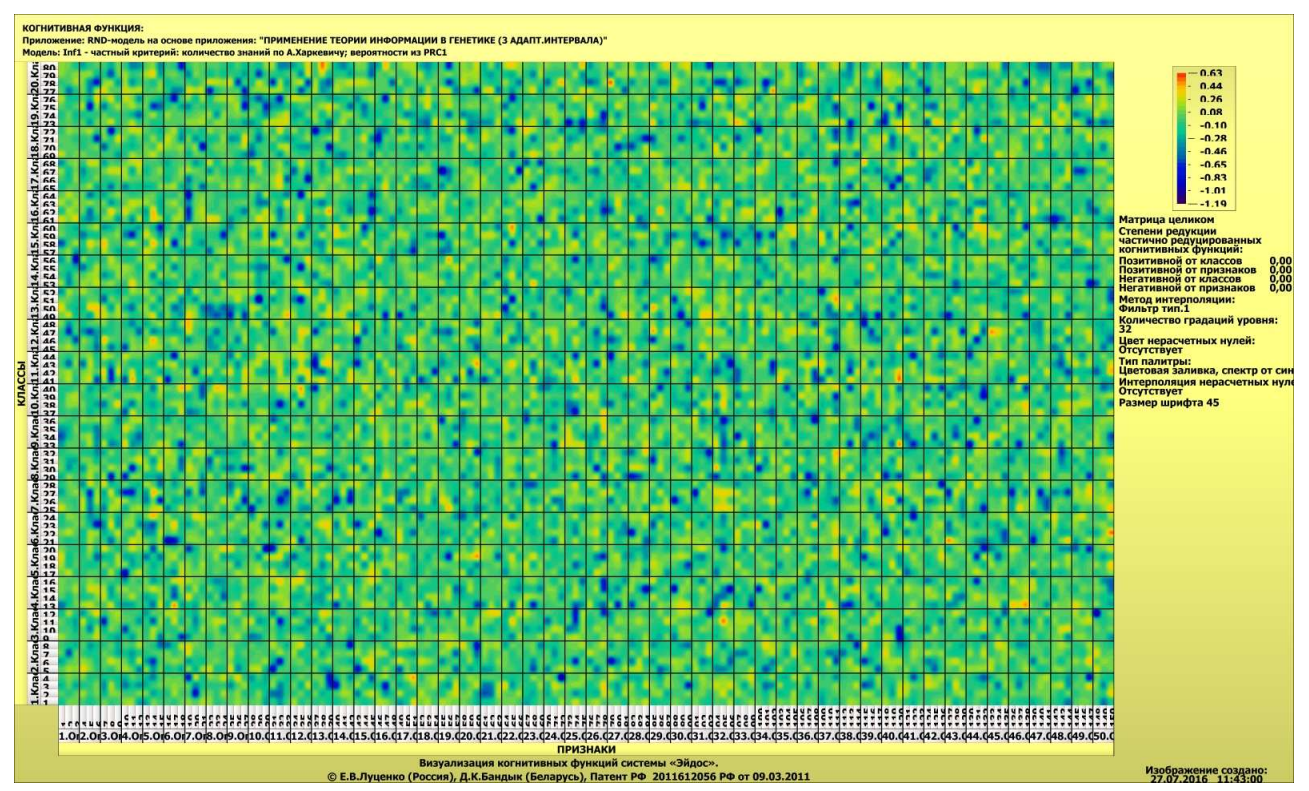

Рисунок 27. Когнитивная функция всех подматриц случайной модели INF1

Различие рисунков 26 и 27 очевидно.

\footnotetext{
${ }^{7}$ См., например: http://lc.kubagro.ru/aidos/aidos06_lab/lab_10.htm
} 

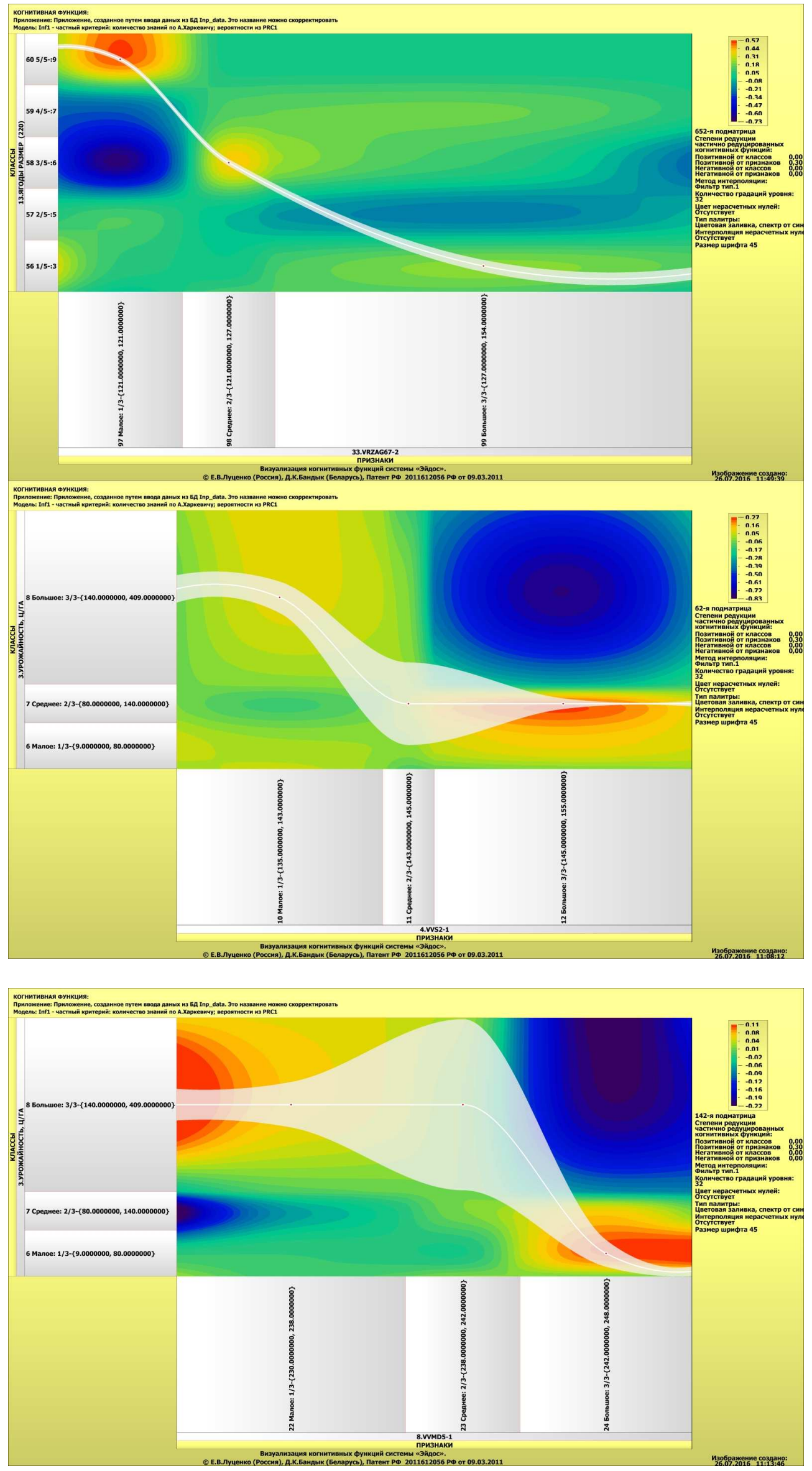


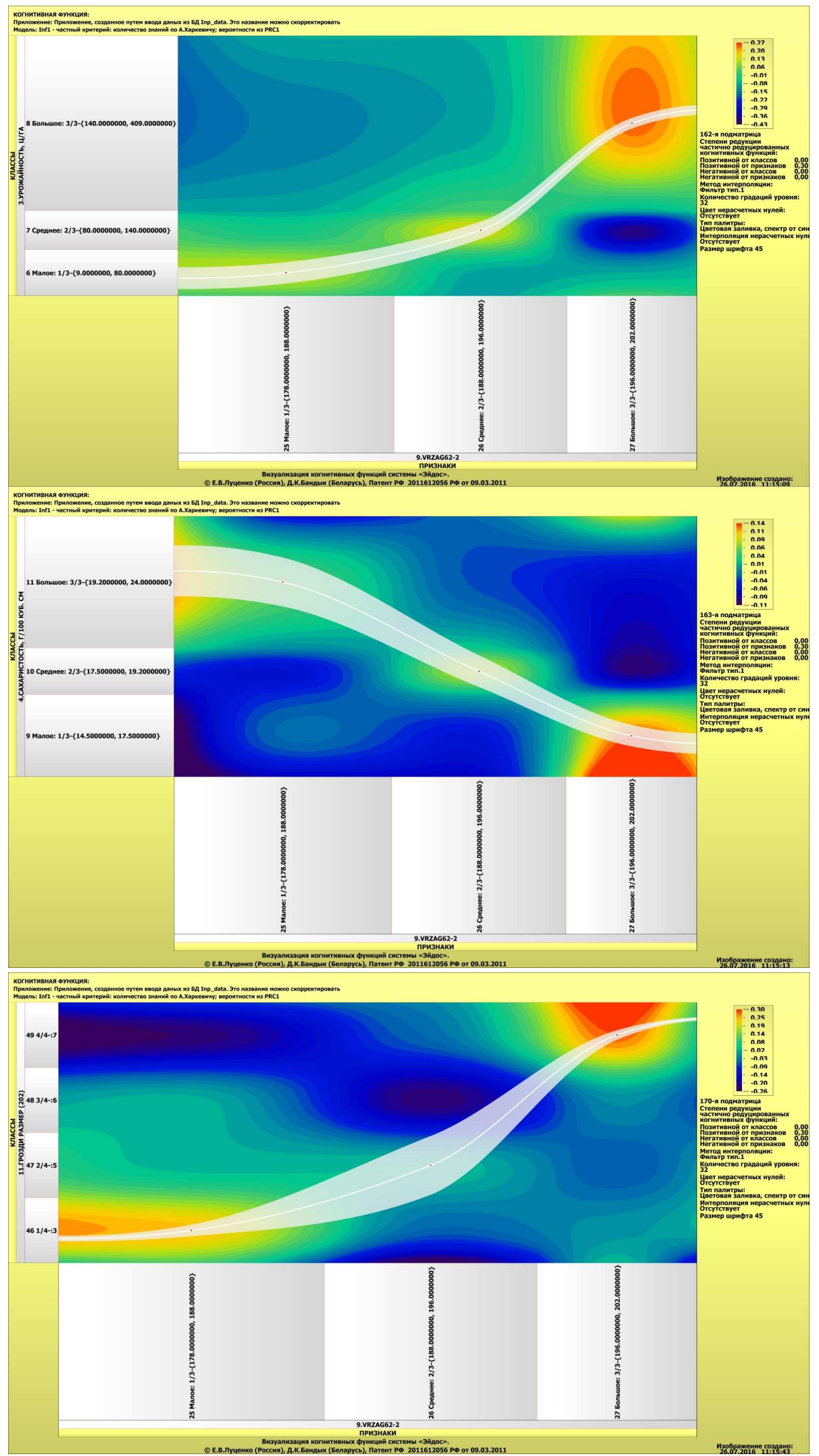




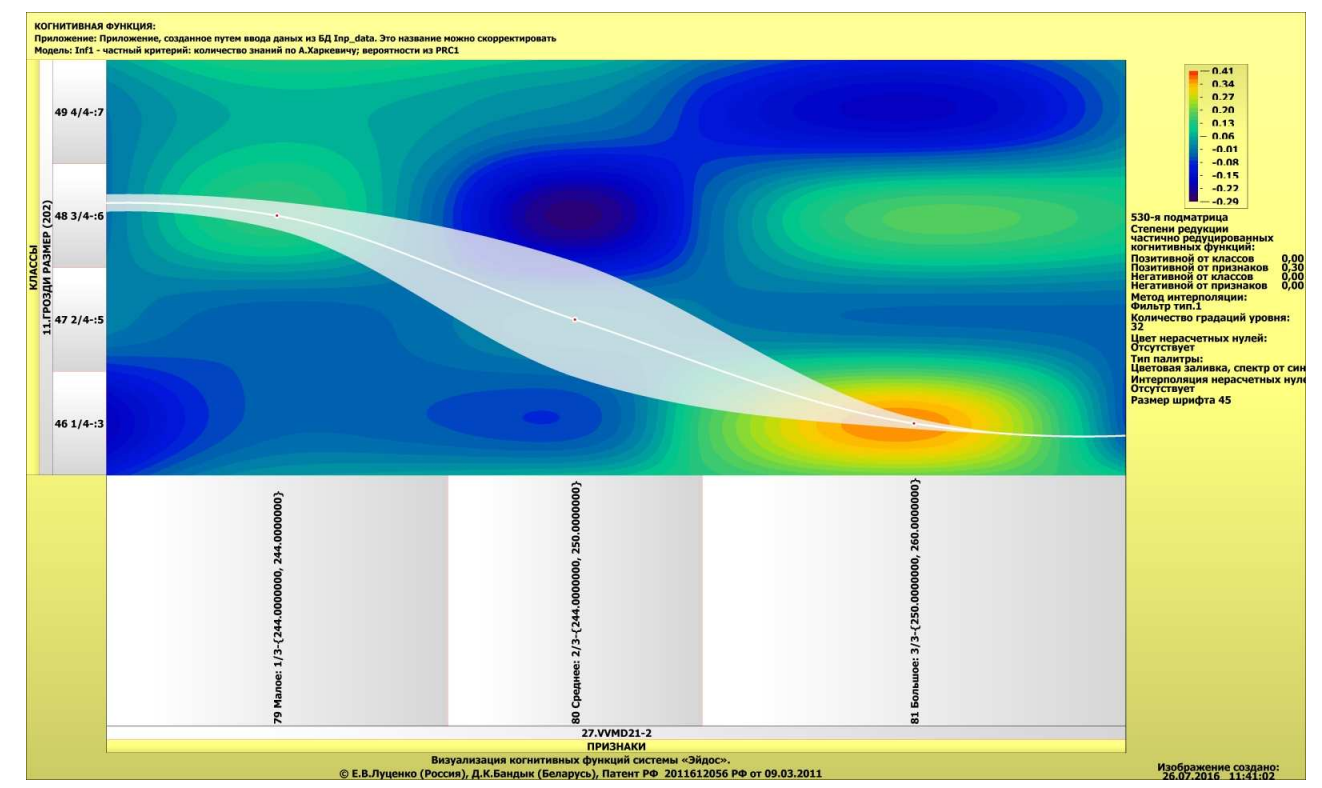

Рисунок 28. Примеры некоторых когнитивных функций

Эти когнитивные функции отражают зависимости степени выраженности различных фенотипических свойств/признаков винограда от степени выраженности определенных генов.

\section{5. Выводы и перспективы}

Общеизвестно, что генетика изучает механизмы наследственности/изменчивости и очень широко пользуется понятием «наследственная информация». При этом генетика под информацией подразумевает содержание генетического кода - структуры молекул ДНК и РНК, входящих в состав клетки живого организма. Генетика изучает механизмы записи, копирования, считывания генетической информации, возможности ее модификации, а также ее влияние на свойства/признаки организма. В разговорном и научном языке прочно закрепились фразы, типа «Гены содержат информацию о признаках и свойствах организма». Парадоксально, но мы не видим попыток определения количества информации, содержащейся в конкретных генах о конкретных фенотипических свойствах/признаках организма. Казалось бы, применение теории информации в генетике является совершенно естественным и напрашивается само собой. Тем более странно, что практически нет работ, посвященных применению теории информации для решения задач генетики. Данная статья призвана в какой-то степени восполнить этот пробел на примере вычисления количества информации в генах о свойствах/признаках различных сортов винограда. В ней рассматривается применение автоматизированного системнокогнитивного анализа (АСК-анализ), его математической модели - системной теории информации и реализующего их программного инструментария - интеллектуальной системы «Эйдос» для решения одной из 
важных задач генетики: определения количества информации, содержащейся в генах о различных фенотипических свойствах/признаках винограда. Для решения этой задачи выполняются следующие этапы: 1) когнитивно-целевая структуризация предметной области; 2) формализация предметной области, т.е. разработка классификационных и описательных шкал и градаций и обучающей выборки; 3) синтез и верификация информационной модели, отражающей количество информации в генах о фенотипических свойствах/признаках (многопараметрическая типизация); 4) вывод информации о генетической системе детерминации фенотипических свойств/признаков (SWOT-анализ феносвойств); 5) вывод информации о силе и направлении влияния конкретного гена на фенотипические свойства/признаки (SWOT-диаграммы генов); 6) решение задачи системной идентификации фенотипических свойств/признаков по наличию тех или иных генов; 7) количественное определение сходства-различия различных фенотипических свойств/признаков по их системе детерминации генами. Конкретное фенотипическое свойство/признак рассматривается как зашумленный генетический текст, включающий как генетическую информацию об истинном феносвойстве/признаке (чистый сигнал), так и шум, искажающий эту информацию, обусловленный случайным воздействием окружающей среды. Программный инструментарий АСК-анализа - интеллектуальная система «Эйдос» - обеспечивает подавление шума и выделение истинного сигнала.

Описанная в статье технология синтеза и применения интеллектуальной измерительной системы может быть применена не только при генетических исследованиях в ампелографии, но и в других предметных областях, чему может способствовать и то, что система «Эйдос» размещена в полном открытом бесплатном доступе на сайте автора по адресу: http://lc.kubagro.ru/aidos/_Aidos-X.htm.

Конечно данная работа далека от завершенности и лишь продемонстрировала возможность применения теории информации и когнитивных технологий в исследованиях в области генетики. В перспективе авторы планируют провести более масштабное исследование на значительно большем объеме исходных данных: большем количестве сортов винограда, большем количестве их фенотипических свойств/признаков и большем количестве генов, причем не только резервных, микросателлитных, но и оказывающих непосредственное влияние на фенотипические свойства/признаки.

Материалы данной статьи могут быть использованы при проведении лабораторных работ по дисциплинам, связанным с интеллектуальными технологиями, представлением знаний и системами искусственного интеллекта, а также по эконометрике, биометрии, экологии, педагогике, психологии, медицине, криминалистике, энтомологии и др. 


\section{Литература ${ }^{8}$}

1. Луценко Е.В. Автоматизированный системно-когнитивный анализ в управлении активными объектами (системная теория информации и ее применение в исследовании экономических, социально-психологических, технологических и организационно-технических систем): Монография (научное издание). - Краснодар: КубГАУ, 2002. 605 c. http://elibrary.ru/item.asp?id=18632909.

2. Орлов А.И., Луценко Е.В. Системная нечеткая интервальная математика. Монография (научное издание). - Краснодар: КубГАУ, 2014, - 600 с. ISBN 978-5-94672757-0. http://elibrary.ru/item.asp?id=21358220.

3. Луценко Е.В. Универсальная когнитивная аналитическая система «Эйдос". Монография (научное издание). - Краснодар: КубГАУ, 2014. - 600 с. ISBN 978-594672-830-0. http://elibrary.ru/item.asp?id=22401787.

4. Луценко Е.В. Исследование влияния подсистем различных уровней иерархии на эмерджентные свойства системы в целом с применением АСК-анализа и интеллектуальной системы "Эйдос" (микроструктура системы как фактор управления ее макросвойствами) / Е.В. Луценко // Политематический сетевой электронный научный журнал Кубанского государственного аграрного университета (Научный журнал КубГАУ) [Электронный ресурс]. - Краснодар: КубГАУ, 2012. - №01(075). С. 638 - 680. - Шифр Информрегистра: 0421200012\0025, IDA [article ID]: 0751201052. - Режим доступа: http://ej.kubagro.ru/2012/01/pdf/52.pdf, 2,688 у.п.л.

5. Перегудов Ф.И., Тарасенко Ф.П. Введение в системный анализ. - М.: Высшая школа, 1989. - 320 с.

6. Перегудов Ф.И., Тарасенко Ф.П. Основы системного анализа. - Томск: Изд-во науч.-техн. лит., 1997. - 389 с.

7. Луценко Е.В. Теоретические основы, технология и инструментарий автоматизированного системно-когнитивного анализа и возможности его применения для сопоставимой оценки эффективности вузов / Е.В. Луценко, В.Е. Коржаков // Политематический сетевой электронный научный журнал Кубанского государственного аграрного университета (Научный журнал КубГАУ) [Электронный ресурс]. - Краснодар: КубГАУ, 2013. - №04(088). С. 340 - 359. - IDA [article ID]: 0881304022. - Режим доступа: http://ej.kubagro.ru/2013/04/pdf/22.pdf, 1,25 у.п.л.

8. Луценко Е.В. Синтез адаптивных интеллектуальных измерительных систем с применением АСК-анализа и системы «Эйдос» и системная идентификация в эконометрике, биометрии, экологии, педагогике, психологии и медицине / Е.В. Луценко // Политематический сетевой электронный научный журнал Кубанского государственного аграрного университета (Научный журнал КубГАУ) [Электронный ресурс]. - Краснодар: КубГАУ, 2016. - №02(116). С. 1 - 60. - IDA [article ID]: 1161602001. - Режим доступа: http://ej.kubagro.ru/2016/02/pdf/01.pdf, 3,75 у.п.Л.

9. Луценко Е.В. Метризация измерительных шкал различных типов и совместная сопоставимая количественная обработка разнородных факторов в системнокогнитивном анализе и системе «Эйдос» / Е.В. Луценко // Политематический сетевой электронный научный журнал Кубанского государственного аграрного университета (Научный журнал КубГАУ) [Электронный ресурс]. - Краснодар: КубГАУ, 2013. №08(092). С. 859 - 883. - IDA [article ID]: 0921308058. - Режим доступа: http://ej.kubagro.ru/2013/08/pdf/58.pdf, 1,562 у.п.л.

10. Стабин И.П., Моисеева В.С. Автоматизированный системный анализ. - М.: Машиностроение, 1984. - 309 с.

\footnotetext{
${ }^{8}$ Ссылки на эти и другие работы автора есть на сайте: http://lc.kubagro.ru/
} 
11. Симанков В.С. Автоматизация системных исследований в альтернативной энергетике. Диссерт. на соиск. уч. ст. докт, техн. наук. По спец.: 05.13.01. http://tekhnosfera.com/avtomatizatsiya-sistemnyh-issledovaniy-v-alternativnoy-energetike.

12. Klir G.J. Architecture of Systems Problem Solving, with D. Elias. - New York:. Plenum Press, 1974. -354 p.

13. Клир Дж. Системология. Автоматизация решения системных задач. - Москва: Радио и связь, 1990. - 538 с. http://www.twirpx.com/file/486296/.

14. Лефевр В.А. Конфликтующие структуры . Издание второе, переработанное и дополненное. - М.: Изд-во «Советское радио», 1973. - 158 с. с ил.

15. Хаббард Дуглас У. Как измерить все, что угодно. Оценка стоимости нематериального в бизнесе / Дуглас У. Хаббард / [Пер. с англ. Е. Пестеревой]. - М.: ЗАО «Олимп-Бизнес», $2009 . \quad-320$ с.: ил. ISBN 978-5-9693-0163-4 (рус.). http://www.twirpx.com/file/1546361/.

16. Сайт автора АСК-анализа проф. Е.В. Луценко: http://lc.kubagro.ru/.

17. Трошин Л.П., Маградзе Д.Н. Ампелографический скрининг генофонда винограда (Учебное наглядное пособие). - Краснодар, 2013. - 120 с.

18. Луценко Е.В. Количественный автоматизированный SWOT- и PEST-анализ средствами АСК-анализа и интеллектуальной системы «Эйдос-Х++» / Е.В. Луценко // Политематический сетевой электронный научный журнал Кубанского государственного аграрного университета (Научный журнал КубГАУ) [Электронный ресурс]. - Краснодар: КубГАУ, 2014. - №07(101). С. 1367 - 1409. - IDA [article ID]: 1011407090 - Peжим доступа: http://ej.kubagro.ru/2014/07/pdf/90.pdf, 2,688 у.п.л.

19. Луценко Е.В. Метод когнитивной кластеризации или кластеризация на основе знаний (кластеризация в системно-когнитивном анализе и интеллектуальной системе «Эйдос») / Е.В. Луценко, В.Е. Коржаков // Политематический сетевой электронный научный журнал Кубанского государственного аграрного университета (Научный журнал КубГАУ) [Электронный ресурс]. - Краснодар: КубГАУ, 2011. - №07(071). С. 528 576. - Шифр Информрегистра: 042110001210253, IDA [article ID]: 0711107040. - Режим доступа: http://ej.kubagro.ru/2011/07/pdf/40.pdf, 3,062 у.п.л.

20. Луценко Е.В. Когнитивные функции как обобщение классического понятия функциональной зависимости на основе теории информации в системной нечеткой интервальной математике / Е.В. Луценко, А.И. Орлов // Политематический сетевой электронный научный журнал Кубанского государственного аграрного университета (Научный журнал КубГАУ) [Электронный ресурс]. - Краснодар: КубГАУ, 2014. №01(095). С. 122 - 183. - IDA [article ID]: 0951401007. - Режим доступа: http://ej.kubagro.ru/2014/01/pdf/07.pdf, 3,875 у.п.л.

21. Луценко Е.В., Бандык Д.К. Подсистема визуализации когнитивных (каузальных) функций системы «Эйдос» (Подсистема «Эйдос-VCF»), Пат. № 2011612056 РФ. Заяв. № 2011610347 РФ 20.01.2011. Опубл. от 09.03.2011. http://lc.kubagro.ru/aidos/2011612056.jpg

22. Луценко Е.В. Лабораторный практикум по интеллектуальным информационным системам: Учебное пособие для студентов специальности "Прикладная информатика (по областям)" и другим экономическим специальностям. 2-е изд., перераб. и доп. - Краснодар: КубГАУ, 2006. - 318 c. http://elibrary.ru/item.asp?id=21683721

23. Биометрическая оценка полиморфизма сортогрупп винограда Пино и Рислинг по морфологическим признакам листьев среднего яруса кроны / Л.П. Трошин, Е.В. Луценко, П.П. Подваленко, А.С. Звягин // Политематический сетевой электронный научный журнал Кубанского государственного аграрного университета (Научный журнал КубГАУ) [Электронный ресурс]. - Краснодар: КубГАУ, 2009. - №08(052). С. 1 - 
14. - Шифр Информрегистра: 042090001210097, IDA [article ID]: 0520908001. - Режим доступа: http://ej.kubagro.ru/2009/08/pdf/01.pdf, 0,875 у.п.л.

24. Луценко Е.В. Решение задач ампелографии с применением АСК-анализа изображений листьев по их внешним контурам (обобщение, абстрагирование, классификация и идентификация) / Е.В. Луценко, Д.К. Бандык, Л.П. Трошин // Политематический сетевой электронный научный журнал Кубанского государственного аграрного университета (Научный журнал КубГАУ) [Электронный ресурс]. - Краснодар: КубГАУ, 2015. - №08(112). С. 862 - 910. - IDA [article ID]: 1121508064. - Режим доступа: http://ej.kubagro.ru/2015/08/pdf/64.pdf, 3,062 у.П.л.

25. Луценко Е.В. Количественное измерение сходства-различия клонов винограда по контурам листьев с применением АСК-анализа и системы «Эйдос» / Е.В. Луценко, Л.П. Трошин, Д.К. Бандык // Политематический сетевой электронный научный журнал Кубанского государственного аграрного университета (Научный журнал КубГАУ) [Электронный ресурс]. - Краснодар: КубГАУ, 2016. - №02(116). С. 1205 - 1228. - IDA [article ID]: 1161602077. - Режим доступа: http://ej.kubagro.ru/2016/02/pdf/77.pdf, 1,5 у.п.л.

26. Анапская ампелографическая коллекция / Е.А. Егоров, О.М. Ильяшенко, А.Г. Коваленко [и др.]. - Краснодар: СКЗНИИСиВ, 2009. - 216 с.

27. Грамотенко П.М., Трошин Л.П. Микросистематика винограда: классификация сортов винограда А.М. Негруля и ее дальнейшее развитие) // Виноградарство и виноделие. - 1994. - № 1. - С. 10-17.

28. Интерактивная ампелография и селекция винограда: (Сб. материалов Междунар. симп.). - Краснодар: КубГАУ, 2012. - 264 с.

29. Операционные данные ампелографической коллекции "Магарач" за 1985-1987 гг. / Л.П. Трошин, А.М. Панарина, А.М. Пискарева [и др.]; ВНИИВиПП "Магарач". Ялта, 1988. - 86 с.

30. Трошин Л.П. Ампелография и селекция винограда. - Краснодар: РИЦ «Вольные мастера», 1999. - 138 с.

31. Трошин Л.П. Лучшие сорта винограда Евразии. - Краснодар: Алви-Дизайн, 2006. $-224 \mathrm{c}$.

32. Трошин Л. П., Федоров Ю. К. Биометрический анализ генофонда винограда / ВНИИВиПП "Магарач". - Ялта, 1988. - 90 с.

33. Трошин Л.П. Ампелографическая и селекционная научно-исследовательская работа Кубанского госагроуниверситета [Электронный ресурс] // Науч. журн. КубГАУ. - Краснодар: КубГАУ, 2012. - № 07 (81). - С. 524-544. - Режим доступа: http://ej.kubagro.ru/2012/07/pdf/39.pdf, 1,312 у.п.л.

34. Трошин Л.П., Радчевский П.П. Виноград: иллюстрированный каталог. Районированные, перспективные, тиражные сорта. - Ростов н/Д: Феникс, 2010. - 271 с.: ил. - (Мир садовода).

35. Website:

http://www.bioversityinternational.org/fileadmin/bioversity/publications/pdfs/393.pdf.

36. Website: http://www.diprove.unimi.it/GRAPENET/index.php.

37. Website: http://www.eu-vitis.de/index.php и http://www.vivc.de/index.php.

38. Website: http://www.oiv.int/oiv/info/frplubicationoiv\#desc.

39. Website http://plantgrape.plantnet-project.org/

http://lescepages.free.fr/cepmc.html.

40. Website: http://www.vitis.ru и http://kubsau.ru/chairs/viniculture/.

41. Изучение генетического разнообразия генофода винограда Северного Кавказа / Р. Тёпфер, Э. Мауль, А.В. Милованов и др. // Политематический сетевой электронный научный журнал Кубанского государственного аграрного университета (Научный жур- 
нал КубГАУ) [Электронный ресурс]. - Краснодар: КубГАУ, 2016. - №05(119). С. 1337 - 1355. - IDA [article ID]: 1191605090. - Режим доступа: http://ej.kubagro.ru/2016/05/pdf/90.pdf, 1,188 у.п.л.

42. Милованов А.В. Генотипирование новых перспективных технических протоклонов винограда с использованием микросателлитных маркёров / А.В. Милованов, А.С. Звягин, Л.П. Трошин // Политематический сетевой электронный научный журнал Кубанского государственного аграрного университета (Научный журнал КубГАУ) [Электронный ресурс]. - Краснодар: КубГАУ, 2014. - №4(098). С. 139 - 157. - IDA [article ID]: 0981404010. - Режим доступа: http://ej.kubagro.ru/2014/04/pdf/10.pdf, 1,188 у.п.л., импакт-фактор РИНЦ=0,346.

43. Милованов А.В. Генотипирование сортов винограда по молекулярным маркёрам / А.В. Милованов, Л.П. Трошин // Политематический сетевой электронный научный журнал Кубанского государственного аграрного университета (Научный журнал КубГАУ) [Электронный ресурс]. - Краснодар: КубГАУ, 2014. - №02(096). С. 53 - 65. IDA [article ID]: 0961402005. - Режим доступа: http://ej.kubagro.ru/2014/02/pdf/05.pdf, 0,812 у.п.Л., импакт-фактор РИНЦ=0,346.

44. Трошин Л.П., Милованов А.В., Звягин А.С. Ампело-генетический скрининг перспективных столовых и технических сортов и протоклонов винограда // Виноделие и виноградарство. - 2015. - № 2. - С. 33-36.

45. Трошин Л.П., Милованов А.В., Звягин А.С. Этюд совершенствования клоновой селекции винограда // Магарач. Виноградарство и виноделие. - 2015. - №3. - С. 3336.

46. Хильчевская Р.И. Роль асимметрии-симметрии материи в процессах происхождения жизни на Земле // Ж-л ВХО им. Д.И. Менделеева, Том XXV4, 1980 г. - Издво. «Химия». - С. 418-424. Адрес доступа: http://omdp.narod.ru/gip/rolasim.htm

47. А. Ленинджер. В кн.: Биохимия. - М., Мир, 1974. - С. 869, 655, 661.

\section{Literatura}

1. Lucenko E.V. Avtomatizirovannyj sistemno-kognitivnyj analiz $\mathrm{v}$ upravlenii aktivnymi ob\#ektami (sistemnaja teorija informacii $\mathrm{i}$ ee primenenie $\mathrm{v}$ issledovanii jekonomicheskih, social'no-psihologicheskih, tehnologicheskih i organizacionno-tehnicheskih sistem): Monografija (nauchnoe izdanie). - Krasnodar: KubGAU. 2002. - 605 s. http://elibrary.ru/item.asp?id=18632909.

2. Orlov A.I., Lucenko E.V. Sistemnaja nechetkaja interval'naja matematika. Monografija (nauchnoe izdanie). - Krasnodar, KubGAU. 2014. - 600 s. ISBN 978-5-94672-757-0. http://elibrary.ru/item.asp?id=21358220.

3. Lucenko E.V. Universal'naja kognitivnaja analiticheskaja sistema «Jejdos". Monografija (nauchnoe izdanie). - Krasnodar, KubGAU. 2014. - 600 s. ISBN 978-5-94672-830-0. http://elibrary.ru/item.asp?id=18271217

4. Lucenko E.V. Issledovanie vlijanija podsistem razlichnyh urovnej ierarhii na jemerdzhentnye svojstva sistemy v celom s primeneniem ASK-analiza i intellektual'noj sistemy "Jejdos" (mikrostruktura sistemy kak faktor upravlenija ee makrosvojstvami) / E.V. Lucenko // Politematicheskij setevoj jelektronnyj nauchnyj zhurnal Kubanskogo gosudarstvennogo agrarnogo universiteta (Nauchnyj zhurnal KubGAU) [Jelektronnyj resurs]. - Krasnodar: KubGAU, 2012. - №01(075). S. 638 - 680. - Shifr Informregistra: 042120001210025, IDA [article ID]: 0751201052. - Rezhim dostupa: http://ej.kubagro.ru/2012/01/pdf/52.pdf, 2,688 u.p.l.

5. Peregudov F.I., Tarasenko F.P. Vvedenie v sistemnyj analiz. M.: Vysshaja shkola, 1989. - $320 \mathrm{~s}$. 
6. Peregudov F. I., Tarasenko F. P. Osnovy sistemnogo analiza. Tomsk Izd-vo nauch.tehn. lit. 1997. - 389 s.

7. Lucenko E.V. Teoreticheskie osnovy, tehnologija i instrumentarij avtomatizirovannogo sistemno-kognitivnogo analiza i vozmozhnosti ego primenenija dlja sopostavimoj ocenki jeffektivnosti vuzov / E.V. Lucenko, V.E. Korzhakov // Politematicheskij setevoj jelektronnyj nauchnyj zhurnal Kubanskogo gosudarstvennogo agrarnogo universiteta (Nauchnyj zhurnal KubGAU) [Jelektronnyj resurs]. - Krasnodar: KubGAU, 2013. - №04(088). S. 340 - 359. - IDA [article ID]: 0881304022. - Rezhim dostupa: http://ej.kubagro.ru/2013/04/pdf/22.pdf, 1,25 u.p.1.

8. Lucenko E.V. Sintez adaptivnyh intellektual'nyh izmeritel'nyh sistem s primeneniem ASK-analiza i sistemy «Jejdos» i sistemnaja identifikacija v jekonometrike, biometrii, jekologii, pedagogike, psihologii i medicine / E.V. Lucenko // Politematicheskij setevoj jelektronnyj nauchnyj zhurnal Kubanskogo gosudarstvennogo agrarnogo universiteta (Nauchnyj zhurnal KubGAU) [Jelektronnyj resurs]. - Krasnodar: KubGAU, 2016. - №02(116). S. 1 60. - $\quad$ IDA [article ID]: 1161602001. - Rezhim dostupa: http://ej.kubagro.ru/2016/02/pdf/01.pdf, 3,75 u.p.1.

9. Lucenko E.V. Metrizacija izmeritel'nyh shkal razlichnyh tipov i sovmestnaja sopostavimaja kolichestvennaja obrabotka raznorodnyh faktorov v sistemno-kognitivnom analize i sisteme «Jejdos» / E.V. Lucenko // Politematicheskij setevoj jelektronnyj nauchnyj zhurnal Kubanskogo gosudarstvennogo agrarnogo universiteta (Nauchnyj zhurnal KubGAU) [Jelektronnyj resurs]. - Krasnodar: KubGAU, 2013 - №08(092). S. 859 - 883. - IDA [article ID]: 0921308058. - Rezhim dostupa: http://ej.kubagro.ru/2013/08/pdf/58.pdf, 1,562 u.p.l.

10. Stabin I.P., Moiseeva B.C. Avtomatizirovannyj sistemnyj analiz. - M.: Mashinostroenie, 1984. - 309 s.

11. Simankov V.S. Avtomatizacija sistemnyh issledovanij v al'ternativnoj jenergetike. Dissert. na soisk. uch. st. dokt, tehn. nauk. Po spec.: 05.13.01. http://tekhnosfera.com/avtomatizatsiya-sistemnyh-issledovaniy-v-alternativnoy-energetike.

12. Klir G.J. Architecture of Systems Problem Solving, with D. Elias, Plenum Press, New York. - 354 pp.

13. Klir Dzh. Sistemologija. Avtomatizacija reshenija sistemnyh zadach. Moskva: Radio i svjaz'. 1990. 538 s. http://www.twirpx.com/file/486296/.

14. Lefevr V.A. Konfliktujushhie struktury . Izdanie vtoroe, pererabotannoe i dopolnennoe. - M.: Izd-vo «Sovetskoe radio», 1973. - 158 s. s il.

15. Habbard Duglas U. Kak izmerit' vse, chto ugodno. Ocenka stoimosti nematerial'nogo v biznese / Duglas U. Habbard / [Per. s angl. E. Pesterevoj]. - M.: ZAO «OlimpBiznes», 2009. - 320 s.: il. ISBN 978-5-9693-0163-4 (rus.). http://www.twirpx.com/file/1546361/.

16. Sajt avtora ASK-analiza prof. E.V. Luceko: http://lc.kubagro.ru/.

17. Troshin L.P., Magradze D.N. Ampelograficheskij skrining genofonda vinograda (Uchebnoe nagljadnoe posobie). - Krasnodar, 2013. - $120 \mathrm{~s}$.

18. Lucenko E.V. Kolichestvennyj avtomatizirovannyj SWOT- i PEST-analiz sredstvami ASK-analiza i intellektual'noj sistemy «Jejdos-H++» / E.V. Lucenko // Politematicheskij setevoj jelektronnyj nauchnyj zhurnal Kubanskogo gosudarstvennogo agrarnogo universiteta (Nauchnyj zhurnal KubGAU) [Jelektronnyj resurs]. - Krasnodar: KubGAU, 2014. - №07(101). S. 1367 - 1409. - IDA [article ID]: 1011407090. - Rezhim dostupa: http://ej.kubagro.ru/2014/07/pdf/90.pdf, 2,688 u.p.1.

19. Lucenko E.V. Metod kognitivnoj klasterizacii ili klasterizacija na osnove znanij (klasterizacija v sistemno-kognitivnom analize i intellektual'noj sisteme «Jejdos») / E.V. Lucenko, V.E. Korzhakov // Politematicheskij setevoj jelektronnyj nauchnyj zhurnal Kubanskogo gosudarstvennogo agrarnogo universiteta (Nauchnyj zhurnal KubGAU) [Jel- 
ektronnyj resurs]. - Krasnodar: KubGAU, 2011. - №07(071). S. 528 - 576. - Shifr Informregistra: 0421100012\0253, IDA [article ID]: 0711107040. - Rezhim dostupa: http://ej.kubagro.ru/2011/07/pdf/40.pdf, 3,062 u.p.l.

20. Lucenko E.V. Kognitivnye funkcii kak obobshhenie klassicheskogo ponjatija funkcional'noj zavisimosti na osnove teorii informacii v sistemnoj nechetkoj interval'noj matematike / E.V. Lucenko, A.I. Orlov // Politematicheskij setevoj jelektronnyj nauchnyj zhurnal Kubanskogo gosudarstvennogo agrarnogo universiteta (Nauchnyj zhurnal KubGAU) [Jelektronnyj resurs]. - Krasnodar: KubGAU, 2014. - №01(095). S. 122 - 183. - IDA [article ID]: 0951401007. - Rezhim dostupa: http://ej.kubagro.ru/2014/01/pdf/07.pdf, 3,875 u.p.l.

21. Lucenko E.V., Bandyk D.K. Podsistema vizualizacii kognitivnyh (kauzal'nyh) funkcij sistemy «Jejdos» (Podsistema «Jejdos-VCF»), Pat. № 2011612056 RF. Zajav. № 2011610347 RF 20.01.2011. Opubl. 09.03 .2011$. http://lc.kubagro.ru/aidos/2011612056.jpg.

22. Lucenko E.V. Laboratornyj praktikum po intellektual'nym informacionnym sistemam: Uchebnoe posobie dlja studentov special'nosti "Prikladnaja informatika (po oblastjam)" i drugim jekonomicheskim special'nostjam. 2-e izd.,pererab. i dop. - Krasnodar: KubGAU, 2006. -318 s. http://elibrary.ru/item.asp?id=21683721.

23. Biometricheskaja ocenka polimorfizma sortogrupp vinograda Pino i Risling po morfologicheskim priznakam list'ev srednego jarusa krony / L.P. Troshin, E.V. Lucenko, P.P. Podvalenko, A.S. Zvjagin // Politematicheskij setevoj jelektronnyj nauchnyj zhurnal $\mathrm{Ku}-$ banskogo gosudarstvennogo agrarnogo universiteta (Nauchnyj zhurnal KubGAU) [Jelektronnyj resurs]. - Krasnodar: KubGAU, 2009. - №08(052). S. 1 - 14. - Shifr Informregistra: 042090001210097, IDA [article ID]: 0520908001. - Rezhim dostupa: http://ej.kubagro.ru/2009/08/pdf/01.pdf, 0,875 u.p.1.

24. Lucenko E.V. Reshenie zadach ampelografii s primeneniem ASK-analiza izobrazhenij list'ev po ih vneshnim konturam (obobshhenie, abstragirovanie, klassifikacija i identifikacija) / E.V. Lucenko, D.K. Bandyk, L.P. Troshin // Politematicheskij setevoj jelektronnyj nauchnyj zhurnal Kubanskogo gosudarstvennogo agrarnogo universiteta (Nauchnyj zhurnal KubGAU) [Jelektronnyj resurs]. - Krasnodar: KubGAU, 2015. - №08(112). S. 862 - 910. IDA [article ID]: 1121508064. - Rezhim dostupa: http://ej.kubagro.ru/2015/08/pdf/64.pdf, 3,062 u.p.1.

25. Lucenko E.V. Kolichestvennoe izmerenie shodstva-razlichija klonov vinograda po konturam list'ev s primeneniem ASK-analiza i sistemy «Jejdos» / E.V. Lucenko, L.P. Troshin, D.K. Bandyk // Politematicheskij setevoj jelektronnyj nauchnyj zhurnal Kubanskogo gosudarstvennogo agrarnogo universiteta (Nauchnyj zhurnal KubGAU) [Jelektronnyj resurs]. - Krasnodar: KubGAU, 2016. - №02(116). S. 1205 - 1228. - IDA [article ID]: 1161602077. - Rezhim dostupa: http://ej.kubagro.ru/2016/02/pdf/77.pdf, 1,5 u.p.1.

26. Anapskaja ampelograficheskaja kollekcija / E.A. Egorov, O.M. Il'jashenko, A.G. Kovalenko [i dr.]. - Krasnodar: SKZNIISiV, 2009. - 216 s.

27. Gramotenko P. M., Troshin L.P. Mikrosistematika vinograda klassifikacija sortov vinograda A.M. Negrulja i ee dal'nejshee razvitie) // Vinogradarstvo i vinodelie. - 1994. - № 1. - S. 10-17.

28. Interaktivnaja ampelografija i selekcija vinograda: (Sb. materialov Mezhdunar. simp.). - Krasnodar: KubGAU, 2012. - 264 s.

29. Operacionnye dannye ampelograficheskoj kollekcii "Magarach" za 1985-1987 gg. / L.P. Troshin, A.M. Panarina, A.M. Piskareva [i dr.]; VNIIViPP "Magarach". - Jalta, 1988. $86 \mathrm{~s}$.

30. Troshin L.P. Ampelografija i selekcija vinograda. - Krasnodar: RIC «Vol'nye mastera», 1999. $-138 \mathrm{~s}$. 
31. Troshin L.P. Luchshie sorta vinograda Evrazii. - Krasnodar: Alvi-Dizajn, 2006. $224 \mathrm{~s}$.

32. Troshin L.P., Fedorov Ju.K. Biometricheskij analiz genofonda vinograda / VNIIViPP "Magarach". - Jalta, 1988. - 90 s.

33. Troshin L. P. Ampelograficheskaja i selekcionnaja nauchno-issledovatel'skaja rabota Kubanskogo gosagrouniversiteta [Jelektronnyj resurs] // Nauch. zhurn. KubGAU. - Krasnodar: KubGAU, 2012. - № 07 (81). - S. 524-544. - Rezhim dostupa: http://ej.kubagro.ru/2012/07/pdf/39.pdf, 1,312 u.p.l.

34. Troshin L.P., Radchevskij P.P. Vinograd: illjustrirovannyj katalog. Rajonirovannye, perspektivnye, tirazhnye sorta. - Rostov n/D: Feniks, 2010. - 271 s.: il. - (Mir sadovoda).

35. Website:

http://www.bioversityinternational.org/fileadmin/bioversity/publications/pdfs/393.pdf.

36. Website: http://www.diprove.unimi.it/GRAPENET/index.php.

37. Website: http://www.eu-vitis.de/index.php i http://www.vivc.de/index.php.

38. Website: http://www.oiv.int/oiv/info/frplubicationoiv\#desc.

39. Website http://plantgrape.plantnet-project.org/ i

http://lescepages.free.fr/cepmc.html.

40. Website: http://www.vitis.ru i http://kubsau.ru/chairs/viniculture/.

41. Izuchenie geneticheskogo raznoobrazija genofoda vinograda Severnogo Kavkaza / R.Tjopfer, Je.Maul', A.V.Milovanov i dr. // Politematicheskij setevoj jelektronnyj nauchnyj zhurnal Kubanskogo gosudarstvennogo agrarnogo universiteta (Nauchnyj zhurnal KubGAU) [Jelektronnyj resurs]. - Krasnodar: KubGAU, 2016. - №05(119). S. 1337 - 1355. - IDA [article ID]: 1191605090. - Rezhim dostupa: http://ej.kubagro.ru/2016/05/pdf/90.pdf, 1,188 u.p.l.

42. Milovanov A.V. Genotipirovanie novyh perspektivnyh tehnicheskih protoklonov vinograda s ispol'zovaniem mikrosatellitnyh markjorov / A.V. Milovanov, A.S. Zvjagin, L.P. Troshin // Politematicheskij setevoj jelektronnyj nauchnyj zhurnal Kubanskogo gosudarstvennogo agrarnogo universiteta (Nauchnyj zhurnal KubGAU) [Jelektronnyj resurs]. - Krasnodar: KubGAU, 2014. - №04(098). S. 139 - 157. - IDA [article ID]: 0981404010. - Rezhim dostupa: http://ej.kubagro.ru/2014/04/pdf/10.pdf, 1,188 u.p.1., impakt-faktor RINC=0,346.

43. Milovanov A.V. Genotipirovanie sortov vinograda po molekuljarnym markjoram / A.V. Milovanov, L.P. Troshin // Politematicheskij setevoj jelektronnyj nauchnyj zhurnal Kubanskogo gosudarstvennogo agrarnogo universiteta (Nauchnyj zhurnal KubGAU) [Jelektronnyj resurs]. - Krasnodar: KubGAU, 2014. - №02(096). S. 53 - 65. - IDA [article ID]: 0961402005. - Rezhim dostupa: http://ej.kubagro.ru/2014/02/pdf/05.pdf, 0,812 u.p.1., impaktfaktor RINC=0,346.

44. Troshin L.P., Milovanov A.V., Zvjagin A.S. Ampelo-geneticheskij skrining perspektivnyh stolovyh i tehnicheskih sortov i protoklonov vinograda // Vinodelie i vinogradarstvo. - 2015. - № 2. - S. 33-36.

45. Troshin L.P., Milovanov A.V., Zvjagin A.S. Jetjud sovershenstvovanija klonovoj selekcii vinograda // Magarach. Vinogradarstvo i vinodelie. - 2015. - №3. - S. 33-36.

46. Hil'chevskaja R.I. Rol' asimmetrii-simmetrii materii $\mathrm{v}$ processah proishozhdenija zhizni na Zemle. // Zh-1 VHO im.D.I.Mendeleeva, TomXXV,4, 1980g. Izd-vo. «Himija». s. 418-424. Adres dostupa: http://omdp.narod.ru/gip/rolasim.htm.

47. A. Lenindzher. V kn.: Biohimija. - M., Mir, 1974. - S. 869, 655, 661. 